\title{
Economic Geology of the
}

Fort Meade Quadrangle

Polk and Hardee Counties

Florida

$\begin{array}{lllll}\text { GEOOGICAL SURVEY BULLETIN } & 1207\end{array}$

Prepared on behalf of the

U.S. Atomic Energy Commission 


\section{Economic Geology of the}

\section{Fort Meade Quadrangle}

\section{Polk and Hardee Counties}

\section{Florida}

By JAMES B. CATHCART

$\begin{array}{llll}\text { G E O L G I C A L S U R V E Y B L L E T I N } & 1207\end{array}$

Prepared on behalf of the

U.S. Atomic Energy Commission

A study of the phosphate and the associated uranium deposits in the southeastern part of the land-pebble phosphate district of Florida

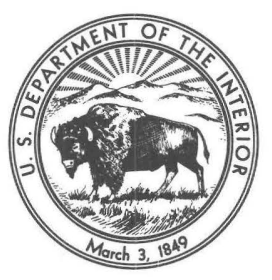




\title{
UNITED STATES DEPARTMENT OF THE INTERIOR
}

\section{STEWART L. UDALL, Secretary}

\section{GEOLOGICAL SURVEY}

\author{
William T. Pecora, Director
}

Library of Congress catalog-card No. GS 66-168 


\section{CONTENTS}

Page

Glossary

Abstract.............. 1

Introduction and acknowledgments

Regional geology

Stratigraphy _. 7

Eocene Series.

Ocala Limestone......... 7

Oligocene Series._. 9

Suwannee Limestone... 9

Miocene Series ....... 9

Tampa Limestone.

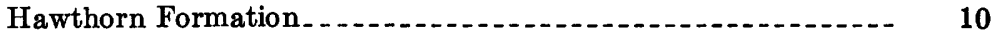

Pliocene Series.

Bone Valley Formation

Pleistocene Series._._. 18

Terrace deposits... 18

Recent deposits

River-pebble deposits_._. 20

Other Recent deposits.... 20

Structure

Mineral composition.

Weathering and erosion.

Economic geology

History of mining . 27

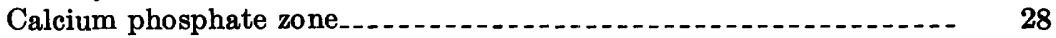

Stratigraphic relations._-_._. 28

Distribution and thickness._. 29

Economic factors........ 29

Relation to the surface of the Hawthorn Formation

Relation to the overburden. 30

Size variations of phosphate nodules. 31

Analytical data.... 31

$\mathrm{P}_{2} \mathrm{O}_{6}$ distribution.

Uranium distribution

$\mathrm{P}_{2} \mathrm{O}_{6}, \mathrm{U}_{3} \mathrm{O}_{8}$, fluorine relations. $\ldots . . .37$

BPL, acid-insoluble content relations_._._.

Aluminum phosphate zone....... 42

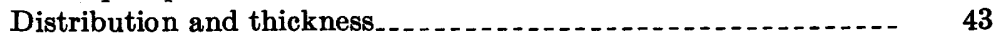

Analytical data........ 43

$\mathrm{P}_{2} \mathrm{O}_{5}$ content...... 43

Uranium content.

$\mathrm{P}_{2} \mathrm{O}_{5}, \mathrm{U}_{3} \mathrm{O}_{8}$ relations....... 45

$\mathrm{CaO}, \mathrm{P}_{2} \mathrm{O}_{5}$ relations

Tonnage calculations

Calcium phosphate zone. 48

Aluminum phosphate zone.......... 49

Phosphate resources in the Hawthorn Formation ........ 50 
Mine and tract descriptions... 50

South Pierce mine... 50

Consolidated tract.

Tilghman tract._.

Waldo-Watson mines.

Jane Jay mine.

Little Charlie tract. $\ldots \ldots \ldots$.

Vandolah tract....... 86

References cited.-_._. 91

Index

\section{ILLUSTRATIONS}

[Plates are in pocket of case]

Plate 1. Geologic map and sections.

2. Subsurface contour map of the erosion surface on the top of limestone or clastic material of the Hawthorn Formation.

3. Isopach map of the calcium phosphate zone.

4. Isopach map of the overburden.

5. Isopleth map of uranium content of the pebble fraction.

6. Isopleth map of uranium content of the concentrate fraction.

7. Diagrams showing distribution of uranium, fluorine, and phosphorus pentoxide, stratigraphically and by mesh fractions, South Pierce mine.

8. Isopach map of the aluminum phosphate zone.

9. Isopleth map of uranium content of the aluminum phosphate zone.

10. Isometric fence diagram of the Watson mine.

Figure 1. Index map of west-central peninsular Florida, showing location of Fort Meade quadrangle

2. Sketch map of topography, drainage, and physiographic divisions

3. Stratigraphic section, Watson mine

4. Sketch section of channel, Watson mine

5. Log of drill hole, $\mathrm{SE}^{1 / 4} \mathrm{NE}^{1} / 4$ sec. 34 , T. 32 S., R. 24 E., showing lithology and economic geology

6. Map showing the distribution of pebble and concentrate in the calcium phosphate zone.

7-9. Diagrams showing:

7. Uranium distribution in screen fractions of mine-face section, SE $1 / 4 \mathrm{SW}^{1} / 4$ sec. 32 , T. 31 S., R. 24 E. . ....

8. $\mathrm{U}_{3} \mathrm{O}_{8}, \mathrm{BPL}$ relations in screened fractions of samples from the calcium phosphate zone

9. $\mathrm{U}_{3} \mathrm{O}_{8}, \mathrm{BPL}$ and acid insoluble, BPL relations, calcium phosphate zone . . . . .

10. Map showing distribution of $\mathrm{P}_{2} \mathrm{O}_{5}$ in the aluminum phosphate zone 
Figure 11. Scatter diagram showing $\mathrm{P}_{2} \mathrm{O}_{5}, \mathrm{U}_{3} \mathrm{O}_{8}$ and $\mathrm{P}_{2} \mathrm{O}_{6}, \mathrm{CaO}$ relations in the aluminum phosphate zone

12. Log of drill hole in the $\mathrm{SW} 1 / 4 \mathrm{SE} 1 / 4$ sec. 15 , T. 32 S., R. 24 E., showing lithology and economic geology .

13. Map showing uranium distribution in pebble fraction of calcium phosphate zone, Tilghman tract.............

14. Logs of drill holes showing stratigraphy and economic geology, Tilghman tract

15. Log of drill hole in the SE $1 / 4 \mathrm{SE}^{1 / 4}$ sec. 6, T. 32 S., R. 25 E., showing lithology and economic geology

16. Map showing pebble/concentrate ratio and distribution of land- and river-pebble phosphate, Jane Jay mine ........

17. Maps of the Little Charlie tract.

18. Scatter diagram showing $\mathrm{P}_{2} \mathrm{O}_{5}$, uranium relations in raw samples of the calcium phosphate zone

\section{TABLES}

TABLE 1. Summary of stratigraphy, lithology, and mining terminology --

Page

2. Data from deep-well logs

3. Analytical and mineralogic data from a drill hole in sec. 9, $\mathrm{T}$. 32 S., R. 26 E

4. Analytical data, calcium phosphate zone

5. Analytical data for samples of single lithologic units of the calcium phosphate zone.

6. Analytical data and distribution of $\mathrm{P}_{2} \mathrm{O}_{5}, \mathrm{U}_{3} \mathrm{O}_{8}, \mathrm{CaO}, \mathrm{Al}_{2} \mathrm{O}_{3}$, and $\mathrm{Fe}_{2} \mathrm{O}_{3}$ in the screen fractions of the aluminum phosphate zone

7. Indicated reserves, aluminum phosphate zone

8. Data on tonnage and grade of phosphate in the Hawthorn Formation

9. Screen tests and chemical analyses, upper part of the Hawthorn Formation

10. Distribution of $\mathrm{P}_{2} \mathrm{O}_{5}, \mathrm{U}_{3} \mathrm{O}_{8}$, and other elements in the screen fractions of the aluminum phosphate zone at a drill hole, Consolidated tract

11. Screen data and chemical analyses, lower part of the Hawthorn Formation

12. Screen and analytical data and distribution of $\mathrm{P}_{2} \mathrm{O}_{5}$ and uranium, washer debris areas, Jane Jay mine

13. Comparison of phosphate in the Bone Valley and Hawthorn Formations, Vandolah tract. 


\section{GLOSSARY}

Mining terms used locally in the land-pebble phosphate district have been described in a previous report (Cathcart, 1963a). T'erms used in this report are briefly described as follows :

Aluminum phosphate zone, zone of ground-water alteration, characterized by aluminum phosphate minerals.

Bedclay, plastic, water-saturated calcareous clay containing phosphate nodules. Residuum of the Hawthorn Formation.

Bedrock, material too hard to penetrate in prospect drilling. Limestone or dolomite of the Hawthorn Formation.

BPL, bone phosphate of lime $=$ percent $\mathrm{P}_{2} \mathrm{O}_{5} \times 2.185$.

Calcium phosphate zone, unconsolidated sandy clay or clayey sand, characterized by rounded particles of carbonate-fluorapatite.

Concentrate, fine phosphate product, $-14+150$ mesh $(-1 \mathrm{~mm}+0.1 \mathrm{~mm})$ in size. Separated from quartz sand by flotation methods.

Driftrock, coarse sand or conglomerate of phosphate nodules and minor quartz grains. Contains little or no clay.

Hardpan, iron (limonite) cemented sand or clayey sand.

Leached zone, used by the mining companies to designate the possibly economic part of the aluminum phosphate zone.

Matrix, the economic part of the calcium phosphate zone.

Nodule, irregular rounded particle of any size. Used in this report to designate the phosphate particles.

Overburden, waste material above the matrix.

Pebble, coarse phosphate product, +14 mesh $(+1 \mathrm{~mm})$ in size.

Sandrock, sand cemented by aluminum phosphate minerals or, rarely, by silica.

Screen size, mesh-size data throughout the report are in Tyler sieve numbers.

Slime, -150 mesh $(-0.1 \mathrm{~mm})$. Includes silt and clay.

Tailings, -14+150 mesh quartz sand, separated from phosphate by flotation methods. 


\title{
ECONOMIC GEOLOGY OF THE FORT MEADE QUADRANGLE, POLK AND HARDEE COUNTIES FLORIDA
}

\author{
By JaMes B. CATHCART
}

\begin{abstract}
The Fort Meade quadrangle, in west-central peninsular Florida, is within the land-pebble phosphate district and is part of the Gulf Coastal Plain. Formations exposed in the mining pits of the area or in outcrops along the major: streams include the Hawthorn Formation of early and middle Miocene age and the Bone Valley Formation of Pliocene age. Loose sands that blanket the surface of the quadrangle are of Pleistocene age. Formations older than the Hawthorn-the Ocala Limestone of late Eocene age, the Suwannee Limestone of late Oligocene age, and the Tampa Limestone of early Miocene age-are known only from two deep drill holes.

The Hawthorn Formation consists of an upper, noncalcareous clastic part only a few feet thick, and a lower part about 100 feet thick, which is composed dominantly of limestone altered in the top few feet to calcareous clay. Phosphate nodules, low in $\mathrm{P}_{2} \mathrm{O}_{5}$ content, make up about 8 percent of the rock of both parts of the Hawthorn Formation. After the deposition of the Hawthorn Formation erosion produced a valley-and-ridge topography ; ridges are modified by a welldeveloped karst.

The Bone Valley Formation unconformably overlies the Hawthorn Formation and is divided into a lower phosphorite unit and an upper clayey sand unit containing little phosphate.

In the area of the higher flatwoods in the western part of the quadrangle the lower unit of the Bone Valley is a bedded and crossbedded sand containing coarse brown and black phosphate nodules; near the Peace River, in the eastern part of the quadrangle, the unit consists of clayey sand or sandy clay containing fine brown, amber, and white phosphate nodules. The lower unit ranges in thickness from 0 to about 50 feet and is thickest over low areas on the Hawthorn surface.

The upper unit of the Bone Valley is a white, gray, or gray-green clayey sand containing small amounts of phosphate nodules. The unit ranges in thickness from 0 to about 30 feet. The contact between the upper and lower units is gradational.
\end{abstract}

The Bone Valley Formation is overlain by quartz sand of Pleistocene age. The contact is disconformable, irregular in detail, and marked by sand-filled channels, which in places cut through the Bone Valley.

Intense weathering, during at least three periods, altered the phosphatic sedimentary rocks in the quadrangle. During the first period the karst topography on the Hawthorn Formation was formed and most of the upper clastic 
part of the formation was eroded away. Chemical weathering of the lower, calcareous part of the Hawthorn removed calcium carbonate and left a quartzand phosphate-enriched residuum that was reworked into the base of the Bone Valley Formation. During the second period, after deposition of the Bone Valley Formation, intense lateritic weathering formed the aluminum phosphate zone. During the third period, after deposition of the loose sand, a ground-water podzol, typified by the Leon soil, either was formed in the surficial materials or was superimposed on the aluminum phosphate zone.

Mining of phosphate in the Fort Meade quadrangle began shortly before 1892 and has continued to the present. River-pebble phosphate was mined along the Peace River until about 1908. The phosphate deposits are in the calcium phosphate zone and include rocks of both early and middle Miocene and Pliocene ages. Most of the minable reserves are in the rocks of the lower unit of the Bone Valley Formation of Pliocene age. Reserves of recoverable phosphate in the area prospected total 317 million long tons. Additional reserves are present in the unprospected areas of the quadrangle. A total of about 40,000 long tons of metallic uranium is present in the phosphate of the prospected area. The aluminum phosphate zone, a potentially economic zone, is present throughout the quadrangle; reserves total about 250 million long tons of material, which contains about 5 percent $\mathrm{P}_{2} \mathrm{O}_{5}$ and 0.009 percent $\mathrm{U}_{3} \mathrm{O}_{8}$. The Hawthorn Formation contains an additional $1 \frac{1}{2}$ billion long tons of phosphate nodules, a potential resource for the future.

\section{INTRODUCTION AND ACKNOWLEDGMENTS}

The Fort Meade quadrangle is in west-central peninsular Florida between lat $27^{\circ} 30^{\prime}$ and $27^{\circ} 45^{\prime} \mathrm{N}$. and long $81^{\circ} 45^{\prime}$ and $82^{\circ} 00^{\prime} \mathrm{W}$. (fig. 1) and includes parts of Polk and Hardee Counties.

Topography in the quadrangle is flat to gently rolling; elevations range from about 40 feet, in the channel of the Peace River, to 159 feet, on the small ridge in T. 31 S., Rs. 24-25 E. (fig. 2).

The quadrangle is drained to the south by the Peace River and its tributaries: Whidden, Bowlegs, Little Payne, Payne, Little Charlie, Troublesome, and Brushy Creeks.

The area is divided into three physiographic divisions: the ridge area, a small area of well-drained highlands; the flatwoods area, between the ridge area and the stream valleys; and the narrow valleys of the streams (fig. 2).

The ridge area is a rolling upland generally more than $\mathbf{1 5 0}$ feet in elevation. The ridge proper is confined to a small area in the northern part of the quadrangle, in T. 31 S., Rs. 24-25 E. This is the southern tip of the major ridge that extends northwest to the north boundary of T. $27 \mathrm{~S}$. The ridge area is characterized by well-drained sandy soil and a normal growth of scrub oak. Much of the ridge is now planted with citrus groves. In the Fort Meade quadrangle, particularly in the southeast quarter and to the east of the Peace River, small areas at the topographic noses of the interstream divides are well-drained, rolling 



Fraure 1.-Fort Meade quadrangle, land-pebble phosphate district (outlined by hachures), and quadrangles previously described (Cathcart, 1963a, b, c; 1964). 


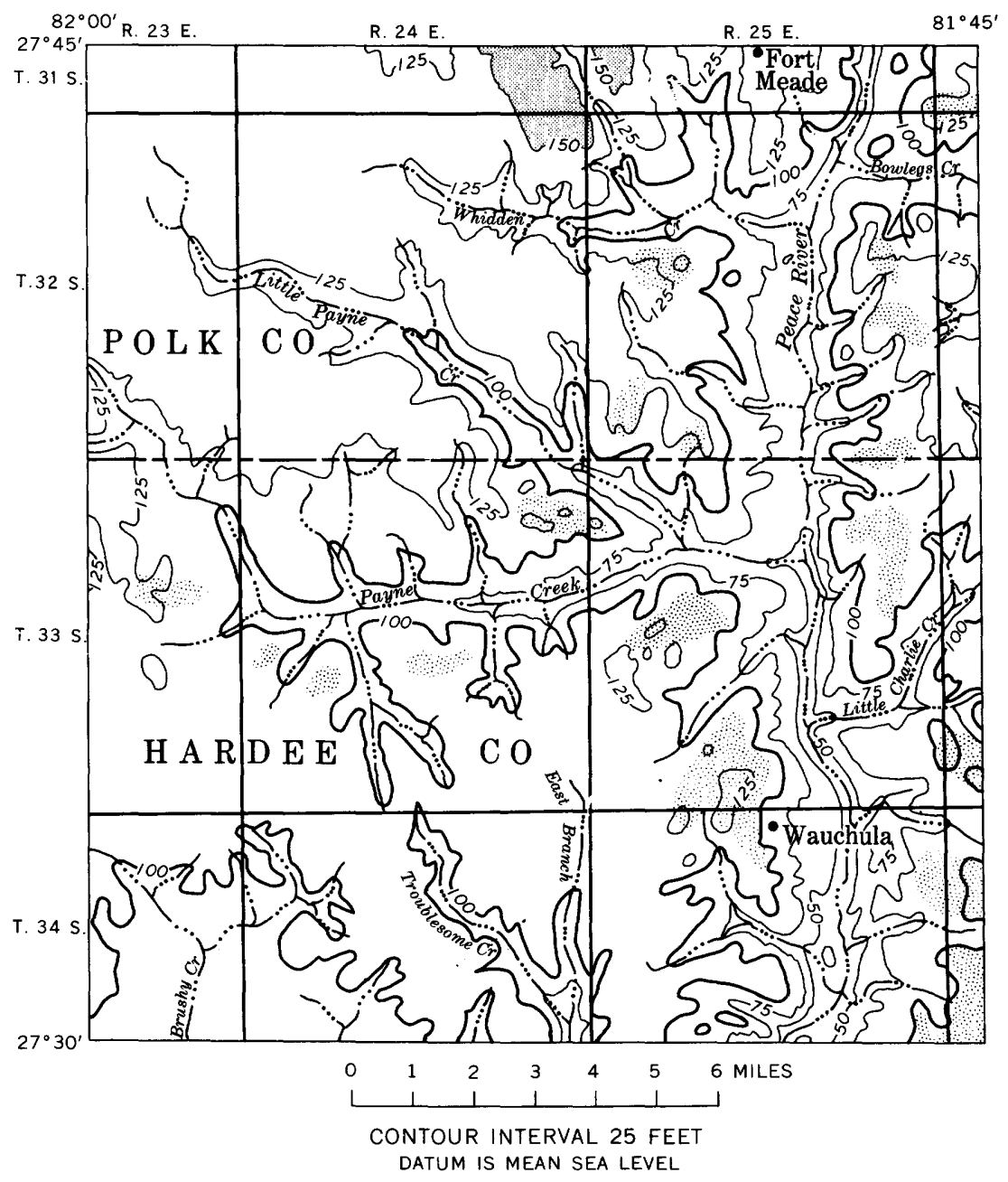

Figure 2.-Topography, drainage, and positions of Pleistocene shorelines in the

Fort Meade quadrangle. Shading represents ridges; strippling represents welldrained, rolling land; unpatterned areas, exclusive of stream valleys, are flatwoods. The 100-foot contour marks the approximate position of Wicomico shoreline; the 150-foot contour marks the approximate position of Okefenokee shoreline. Position of Pleistocene shorelines from MacNeil (1950).

uplands, also planted with citrus groves. These areas belong to the same physiographic unit as the ridge, and they range in elevation from 100 to 135 feet.

The flatwoods area is low lying, nearly level, wooded, and characterized by very abundant small depressions called bayheads or ponds, some of which contain grass or cypress, or both. Most contain water 
only intermittently and may be joined by small winding channels which contain water only during the rainy season. Drainage in the flatwoods area is very poor. Slash and longleaf pine are the common trees, and wiregrass and palmettoes are the underbrush.

The stream valleys are narrow, but the streams, particularly the Peace River, are well defined and are bordered by narrow swamps. The waters of the streams are dark brown owing to a high organic content but are generally free of suspended clay or silt.

The climate is subtropical, and the average rainfall is about 50 inches per year.

The land-pebble phosphate district of Florida includes about 2,000 square miles in Polk, Hillsborough, Hardee, and Manatee Counties. Most of the district is included in six 15-minute quadrangles. Data on four of these quadrangles-Keysville, Plant City, Chicora, and Lakeland-have already been published (Cathcart, 1963a, b, c; 1964). This Fort Meade quadrangle report is the fifth in the series. All the factual data gathered from 1947 to 1953 are being presented in these reports.

Many geologists of the U.S. Geological Survey participated in the field investigation. The writer benefited considerably from informal discussions with these men, who contributed directly to the completion of this report in the following ways: (1) F. N. Houser, H. M. Icke, K. B. Ketner, F. S. MacNeil, and R. H. Stewart measured stratigraphic sections in the mines. (2) M. H. Bergendahl, J. R. Brooks, W. J. Carr, H. B. Dutro, C. H. Gray, Jr., L. J. Kosofsky, S. W. Maher, Louis Pavlides, and R. G. Petersen logged drill holes in the quadrangle. (3) L. V. Blade, W. J. Carr, Alice M. Coleman, C. H. Gray, Jr., L. J. McGreevy, Shirley L. Houser, L. J. Kosofsky, S. W. Maher, Louis Pavlides, and R. G. Petersen constructed or helped in the compilation of many of the maps used in this report.

The work was done on behalf of the Division of Raw Materials of the U.S. Atomic Energy Commission.

It is a pleasure to acknowledge the cooperation of the active mining companies-The American Agricultural Chemical Co. (Continental Oil Co.), American Cyanamid Co., Swift \& Co., and the VirginiaCarolina Chemical Co. (Division of Socony-Mobil Oil Co., Inc.)all of whom allowed access to their mines, furnished prospecting data, and provided samples from drilling. Mr. O. H. Wright furnished prospecting and analytical data on lands prospected by him for American Metal Climax, Inc. Prospecting data and samples were furnished by Mr. Wayne Thomas. Mr. Thomas, whose knowledge of the history of the mining and development of phosphate in Florida is unrivaled, checked the data presented on the history of mining and added many facts. The writer, however, bears full responsibility for any misstatements. 
The maps of uranium distribution were compiled from thousands of chemical and radiometric analyses listing uranium content in percent or percent equivalent. The analyses were made in the Denver and Washington laboratories of the U.S. Geological Survey. Radiation analyses were made by J. T. Bracken, W. R. Champion, E. A. Cisney, C. E. Cox, Jr., F. J. Flanagan, S. P. Furman, J. H. Goode, Jr., Emma H. Humphrey, B. A. McCall, and P. R. Moore. Chemical analyses were made by I. H. Barlow, Sam Bethea, Joseph Budinsky, G. T. Burrows, Alice B. Caemmerer, Esma Campbell, Frank Cuttitta, Grafton Daniels, M. H. Delevaux, David Deibler, M. E. F. Eiland, R. K. Fuyat, J. L. Greene, C. R. Johnson, H. B. Kessler, Harry Levine, S. Lundine, J. W. T. Meadows, Henry Mela, Jr., R. G. Milkey, Roosevelt Moore, Wayne Mountjoy, W. W. Niles, E. Pendergrass, R. B. Randolph, A. J. Robinson, J. N. Rosholt, Jr., J. J. Rowe, M. Schnepfe, J. P. Schuch, Leonard Shapiro, L. Steele, W. P. Tucker, David Venesky, and A. L. White.

\section{REGIONAL GEOLOGY}

The Fort Meade quadrangle is within the land-pebble phosphate district of Florida and is part of the Gulf Coastal Plain. Thin formations of Tertiary and Quaternary age dip to the south, off the Ocala uplift, at a few feet per mile.

Rocks exposed in the mining pits in the area include the Hawthorn Formation of early and middle Miocene age, the Bone Valley Formation of Pliocene age, and unconsolidated surficial sand of Pleistocene age. Pleistocene sand blankets the quadrangle; exposures of older rocks are confined to the mining pits and to the valley of the Peace River.

Formations older than the Hawthorn have been penetrated in the quadrangle by only two deep drill holes. The formations include the Ocala Limestone of late Eocene age, the Suwannee Limestone of late Oligocene age, and the Tampa Limestone of early Miocene age.

The geologic map (pl. 1) was prepared almost exclusively by using data from companies' exploratory drill holes, which are mostly in the north half of the quadrangle.

The geologic map shows the distribution of the pre-Pleistocene formation in the quadrangle. The Hawthorn Formation is exposed along the Peace River and its principal tributaries. The lower unit of the Bone Valley Formation is exposed along most of the stream valleys; the rest of the quadrangle is underlain by the upper clayey sand unit of the Bone Valley Formation.

Stratigraphic correlations are based almost entirely on lithology. A few bedrock samples from drilling in 1953 contained fossils 
(Cathcart and McGreevy, 1959), and fossiliferous limestones were found in the bottoms of mining pits. Fossils were found in the lower unit of the Bone Valley Formation at the No. 11 washer of the South Pierce mine.

The lithologic characteristics of the various formations, on which stratigraphic correlations are based, have been discussed by Cathcart and McGreevy (1959, p. 245).

\section{STRATIGRAPHY}

General stratigraphy of the Fort Meade quadrangle, characteristic lithologies of the various formations, and the local mining terminology are summarized in table 1.

Only the uppermost part of the section is exposed in the mining pits or is penetrated during exploratory drilling. For this reason, detailed knowledge is available only for the top few feet of the Hawthorn Formation, the Bone Valley Formation, and the surficial sand.

Rocks older than the Hawthorn Formation were penerated by only two drill holes in the Fort Meade quadrangle; their stratigraphy is summarized in table 2. Data on the older rocks are so sparse that generalizations regarding distribution, thickness, and lithology must be very vague.

\section{EOCENE SERIES}

OCALA LIMESTONE

The Ocala Limestone is of late Eocene (Jackson) age according to Cooke (1945, p. 53). Applin and Applin (1944) and Vernon (1951) divided the formation into several units; Puri (1953) suggested that sedimentary rocks of Jackson age in Florida be called the Ocala Group and that the different units be raised to formation. Only one drill hole reached the top of the Ocala Limestone in the Fort Meade quadrangle; therefore, the formation could not be divided nor could its thickness be measured.

The upper surface of the Ocala Limestone is 200 feet below sea level at a drill hole in sec. 30 , T. 31 S., R. 25 E., just north of the quadrangle boundary, and it is 435 feet below sea level in the southern part of the quadrangle at the drill hole in sec. 33, T. 33 S., R. $25 \mathrm{E}$. (table 2). The Ocala apparently underlies the entire Fort Meade quadrangle, and Vernon (1951, pl. 2) showed that the surface of his Inglis Member of the Moodys Branch Formation (the lower part of the Jackson Group) dips to the south in the area of the Fort Meade quadrangle.

The Ocala Limestone is unconformably overlain by the Suwannee Limestone of late Oligocene age (Vernon, 1951, p. 158). The Ocala 
TABLE 1.-Summary of stratigraphy, lithology, and mining terminology, Fort Meade quadrangle

[Weathered material-mining terminology: Contacts between overburden and leached zone, and matrix and leached zone, were determined by chemical analysis or from gamma-ray logs]



1 Known to be present only in patches in the northwestern part of the quandrangle.

is a white to cream, granular or chalky, very pure limestone. In the $\log$ of the drill hole, F.S. MacNeil (written commun., 1949) mentioned the foraminifer Lepidocyclina as a characteristic fossil. 
TABLE 2.-Data from deep-well logs, Fort Meade quadrangle

[Stratigraphy by F. S. MacNeil, U.S. Geol. Survey, from logs by Florida Geol. Survey. Elevations and thicknesses given in feet. Datum is mean sea level]

\begin{tabular}{|c|c|c|c|c|c|c|c|c|}
\hline \multirow{2}{*}{ Well location } & \multirow{2}{*}{$\begin{array}{l}\text { Surface } \\
\text { elevation }\end{array}$} & \multicolumn{2}{|c|}{ Hawthorn Formation } & \multicolumn{2}{|c|}{ Tamps Limestone } & \multicolumn{2}{|c|}{ Suwannee Limestone } & \multirow{2}{*}{$\mid \begin{array}{c}\text { Ocala } \\
\text { Limestone } \\
\begin{array}{c}\text { Elevation } \\
\text { of top }\end{array}\end{array}$} \\
\hline & & $\begin{array}{c}\text { Elevation } \\
\text { of top }\end{array}$ & $\begin{array}{c}\text { Thick- } \\
\text { ness }\end{array}$ & $\begin{array}{c}\text { Elevation } \\
\text { of top }\end{array}$ & $\begin{array}{c}\text { Thick- } \\
\text { ness }\end{array}$ & $\begin{array}{c}\text { Elevation } \\
\text { of top }\end{array}$ & $\begin{array}{c}\text { Thick- } \\
\text { ness }\end{array}$ & \\
\hline $\begin{array}{r}\text { Sec. } 33, \text { T. } 33 \text { S., R. } \\
25 \text { E.T.34 S., R.26 } \\
\text { Sec. 6, T. } \\
\text { E. }\end{array}$ & $\begin{array}{l}75 \\
75\end{array}$ & $\begin{array}{r}5 \\
40\end{array}$ & $\begin{array}{l}140 \\
160\end{array}$ & $\begin{array}{l}-135 \\
-120\end{array}$ & $\begin{array}{r}210 \\
185\end{array}$ & $\begin{array}{l}-345 \\
-305\end{array}$ & $\begin{array}{l}90 \\
\text { (1) }\end{array}$ & -435 \\
\hline
\end{tabular}

1 At $495 \mathrm{ft}$ (the total depth of the drill hole) well was still in rocks of Oligocene age; thus, the Suwannee Limestone is at least $115 \mathrm{ft}$ thick, and the top of the Ocala is more than $420 \mathrm{ft}$ below sea level.

\section{OLIGOCENE SERIES}

\section{SUWANNEF LIMESTONE}

The Suwannee Limestone is late Oligocene in age (MacNeil, 1947; Cooke, 1945) and includes all Oligocene rocks in the Fort Meade quadrangle. It is a white to cream, granular limestone containing an average of 5-7 percent of very fine sand or silt and clay (Mossom, 1925).

The Suwannee, which is about 100 feet thick, probably underlies the entire Fort Meade quadrangle; its surface dips very slightly to the south. At the two drill holes in the quadrangle (table 2), the top of the Suwannee is more than 300 feet below sea level. At the hole just to the north of the quadrangle (in sec. 30, T. 31 S., R. 25 E.), the top is about 100 feet below sea level.

The Suwannee Limestone is unconformably overlain by the Tampa Limestone of early Miocene age (Cooke, 1945; Vernon, 1951).

\section{MIOCENE SERIES}

\section{TAMPA LIMESTONE}

The Tampa Limestone of early Miocene age (MacNeil, 1947; Cooke, 1945 ) consists of white, cream, or brown, sandy to slightly sandy limestone or dolomitic limestone containing small amounts of fine phosphate nodules and, in the basal part, a green clay containing a trace of quartz sand and a few fine phosphate nodules.

The Tampa probably underlies the entire Fort Meade quadrangle. To the north of the quadrangle, at the drill hole in sec. 30, T. 31 S., R. $25 \mathrm{E}$., the Tampa is about 100 feet thick; at the two drill holes in the Fort Meade quadrangle, in Tps. 33-34 S. (table 2), it is 185 and 210 feet thick and, therefore, thickens southward. The upper surface of the Tampa dips to the south. 
The contact between the Tampa Limestone and the overlying Hawthorn Formation apparently is conformable in the Fort Meade quadrangle, on the basis of drill-core data from the two deep wells in the quadrangle. It is nonconformable elsewhere in the land-pebble phosphate district, particularly in the Plant City quadrangle to the northwest (Cathcart, 1963b).

\section{HAWTHORN FORMATION}

The Hawthorn Formation, early and middle Miocene in age (MacNeil, 1947; Cooke, 1945), is the oldest rock known from the shallow exploration drilling or from the mining operations. Hard limestone or dolomite of the Hawthorn is the "bedrock" or "basement" rock of the driller, and exploration drill holes throughout the quadrangle bottomed in the Hawthorn Formation. Only the top few feet of the formation was penetrated in drilling or mining, or is exposed in the outcrops of the formation along the Peace River. Along the courses of the streams tributary to the Peace River, the Hawthorn Formation is covered only by sand, of Pleistocene or Recent age; therefore, the Hawthorn is shown along these streams on the geologic map (pl. 1).

\section{THICKNESS}

The Hawthorn Formation is 140 and 160 feet thick at the two deep drill holes in the Fort Meade quadrangle (table 2). At the hole in sec. 30 , T. 30 S., R. 25 E., it is about 100 feet thick; thus, it thickens somewhat to the south. The formation averages about 100 feet in thickness and probably underlies the entire quadrangle.

\section{UPPER SURFACE}

The contour map of the top of the Hawthorn Formation (pl. 2) depicts an erosion surface. The northwestern part of the quadrangle is an area of karst topography, but the remainder has a fairly well developed drainage pattern. Except for a long, narrow, deep trough in the position of the Peace River-the most conspicuous topographic feature shown on the map-the drainage pattern on the Hawthorn surface matches the present drainage only in a very general way. For example, the present valley of Whidden Creek is underlain by a long, narrow ridge on the Hawthorn surface, whereas the valley on the Hawthorn, which corresponds to Whidden Creek, is about half a mile to the south. The drainages on the Hawthorn surface that correspond to Payne and Little Payne Creeks are considerably different in detail from the modern drainages. Almost every stream on the present-day land surface has a crude counterpart on the surface of the Hawthorn, but there are many differences in detail that can be seen on the map.

The drainages on the Hawthorn surface are in part due to erosion by modern streams which have cut down to the surface of the Haw- 
thorn at many places, but in part, the surface of the Hawthorn was formed before the deposition of the Bone Valley Formation. The filling of depressions on the Hawthorn surface with unconsolidated material of the Bone Valley and the consequent compaction of this material may account for the initial positions of the modern streams and for the general correspondence of the modern and post-Hawthorn drainage patterns.

\section{PHYSICAI CFARACTERISTICS}

Two lithologic units of the Hawthorn Formation are exposed in the mining pits or were penetrated by exploratory drilling in the Fort Meade quadrangle: an upper, noncalcareous. clastic part and a lower part composed dominantly of limestone, altered in the top few feet to calcareous clay.

The upper part, whose maximum thickness recorded in drilling is about 10 feet, is a dark-gray-green, olive-green, yellow-green, or brownish-green clayey sand that contains traces to moderate amounts of sand-size brown or black phosphate nodules.

The uper part of the Hawthorn Formation was mapped only at the No. 11 washer of the South Pierce mine, but it was penetrated in drilling at the South Pierce tract, at the northern part of the Consolidated tract, and at a single drill hole at the Tilgham tract; also a similar lithologic unit was described by Matson $(1915$, p. 44) in a section at the Jane Jay mine. Screen tests were made on a typical sample from the upper part of the Hawthorn Formation, in the SE1/4 SW1/4 sec. 32, T. 31 S., R. 24 E. The sample consisted of dark-gray-green fine wellsorted slightly clayey sand containing a small amount of medium- to coarse-sand-size black and brown phosphate grains (table 10). The sample contained a small amount of the +14 mesh (pebble) fraction but no concentrate was recovered, although analysis showed that the feed fraction contained a small amount of phosphate. This sample could not be considered a part of the matrix and was from a part of the pit that was not being mined.

At the No. 11 washer the upper part of the Hawthorn Formation is unconformably overlain by crossbedded sand of the lower unit of the Bone Valley Formation. Animal borings filled with phosphate sand of the Bone Valley extend a few inches into the top of the clayey sand of the upper part of the Hawthorn Formation.

The lower part of the Hawthorn Formation consists mostly of limestone, which has been altered to dolomite where it is close to the surface (Berman, 1953). The two deep drill holes in the quadrangle penetrated 140 and 160 feet of the Hawthorn Formation (table 2), all of which is in the lower part. The rock of the lower part consists of tan, cream, or white, sandy, argillaceous limestone or chalk and a 
few thin beds of calcareous clay. Both the limestone and the calcareous clay beds contain dark-colored fine to very fine phosphate grains.

Throughout the report, hard material of the Hawthorn Formation will be called limestone, but it should be understood that this is the field term and that all samples of limestone checked were dolomitic.

Nearly all the exploratory drill holes bottomed on hard limestone; however, few penetrated far enough into the limestone to recover a sample. The samples recovered have the same general lithology as samples from greater depths. Most of the drill holes penetrated white, cream, buff, yellow, or brown, soft usually water-saturated sandy calcareous clay residual from the limestone. The clay is seldom more than a few feet thick, and everywhere it contains some phosphate nodules. The nodules are brown, white, or gray; usually they are finer and contain less uranium and less $\mathrm{P}_{2} \mathrm{O}_{5}$ than the phosphate nodules of the overlying Bone Valley Formation. The quartzsand fraction of the calcareous clay is fine to medium; much of it is distinctly finer than the quartz fraction of the Bone Valley Formation.

The residual clay (bedclay of local terminology) is a part of the calcium phosphate zone and may be included in the matrix. The clay is in gradational contact with the underlying limestone and tends to be more calcareous there than at its upper contact with the Bone Valley Formation.

There are very few chemical analyses of the phosphate fractions of limestone of the Hawthorn Formation. A single sample of soft, white sandy limestone was screened and analyzed (table 11). The $-35+150$ mesh concentrate fraction is the only one that consists of phosphate particles. All other fractions contain abundant carbonate and some clay and quartz. The ratio of percent fluorine to percent $\mathrm{P}_{2} \mathrm{O}_{5}$ indicates that the phosphate mineral in all the fractions is fluorapatite, and Altschuler, Cisney, and Barlow (1952) have identified the phosphate mineral as a carbonate-fluorapatite. Throughout this report the minoral carbonate-fluorapatite is referred to as apatite.

\section{FossILs}

Hard limestone or dolomite at the South Pierce and Watson mines and limestone cored at three drill holes in the Fort Meade quadrangle all contained fossils which were identified as Hawthorn in age by F. S. MacNeil of the Geological Survey (oral commun., 1951; Cathcart and McGreevy, 1959, p. 230).

Limestones lithologically similar to the fossiliferous limestones were cored at several other drill holes in the quadrangle, and limestones described by Matson (1915, p. 44) from the Tilghman and Jane Jay 
mines are also lithologically similar to the fossiliferous limestones of the Hawthorn Formation; all are probably early and middle Miocene in age.

\section{HAWTHORN-BONE VALLEY CONTACT}

The Hawthorn-Bone Valley contact is unconformable at the No. 11 washer of the South Pierce mine and at the Watson mine-the only localities in the quadrangle where it was seen. At the No. 11 washer only the upper part of the Hawthorn Formation is exposed. It consists of green to gray-green fine to very fine massive clayey sand containing trace amounts of fine to medium phosphate nodules. Animal borings filled with black phosphate sand extend vertically downward from the surface of the clayey sand. The upper part of the Hawthorn Formation is overlain by the lower unit of the Bone Valley Formation, which consists of crossbedded medium to coarse black phosphate grains and quartz sand. At many localities the base of the lower unit is a coarse gravel of phosphate, bones, and teeth. The contact can be readily identified in drill holes as well as in the mine sections. Details of stratigraphy and lithology are shown in $\operatorname{logs}$ B, C, and D (p. 52-54).

At the Watson mine the contact is not as well exposed as at the No. 11 washer. At many localities in the pit the contact is below the water level or is covered by a slumped interval at the base of the pit wall. The contact is marked by a distinct difference between the underlying, massive residuum of the Hawthon Formation and the overlying, bedded phosphorite of the Bone Valley; it is almost flatlying but is somewhat irregular in detail (fig. 3).

The Hawthorn-Bone Valley contact at the Watson mine (fig. 3) dips slightly to the west and is marked by a conglomerate of coarse phosphatized limestone fragments in the base of the Bone Valley. The uranium content of the Hawthorn is much less than that of the Bone Valley. The three samples of the Hawthorn contained 0.002, 0.002 , and 0.003 percent uranium; the samples of the lower phosphorite contained 0.008 and 0.010 percent; and the leached rock at the top of the section contained 0.015 percent uranium. Other sections in this area contained similar amounts of uranium.

N. M. Bramlette (written commun., 1953) noted that at a locality in the Watson mine (probably in the NE1/4 sec. 17, T. 32 S., R. 25 E.) hard dolomite was not exposed, but that the rock at the base of the pit was clayey and silty phosphorite and green clay, probably a residuum of the Hawthorn, and that this material was overlain by bedded matrix of the Bone Valley.

At the Consolidated tract (section $A-A^{\prime}$, pl. 1), the Bone ValleyHawthorn contact is marked by distinct changes in lithology which 


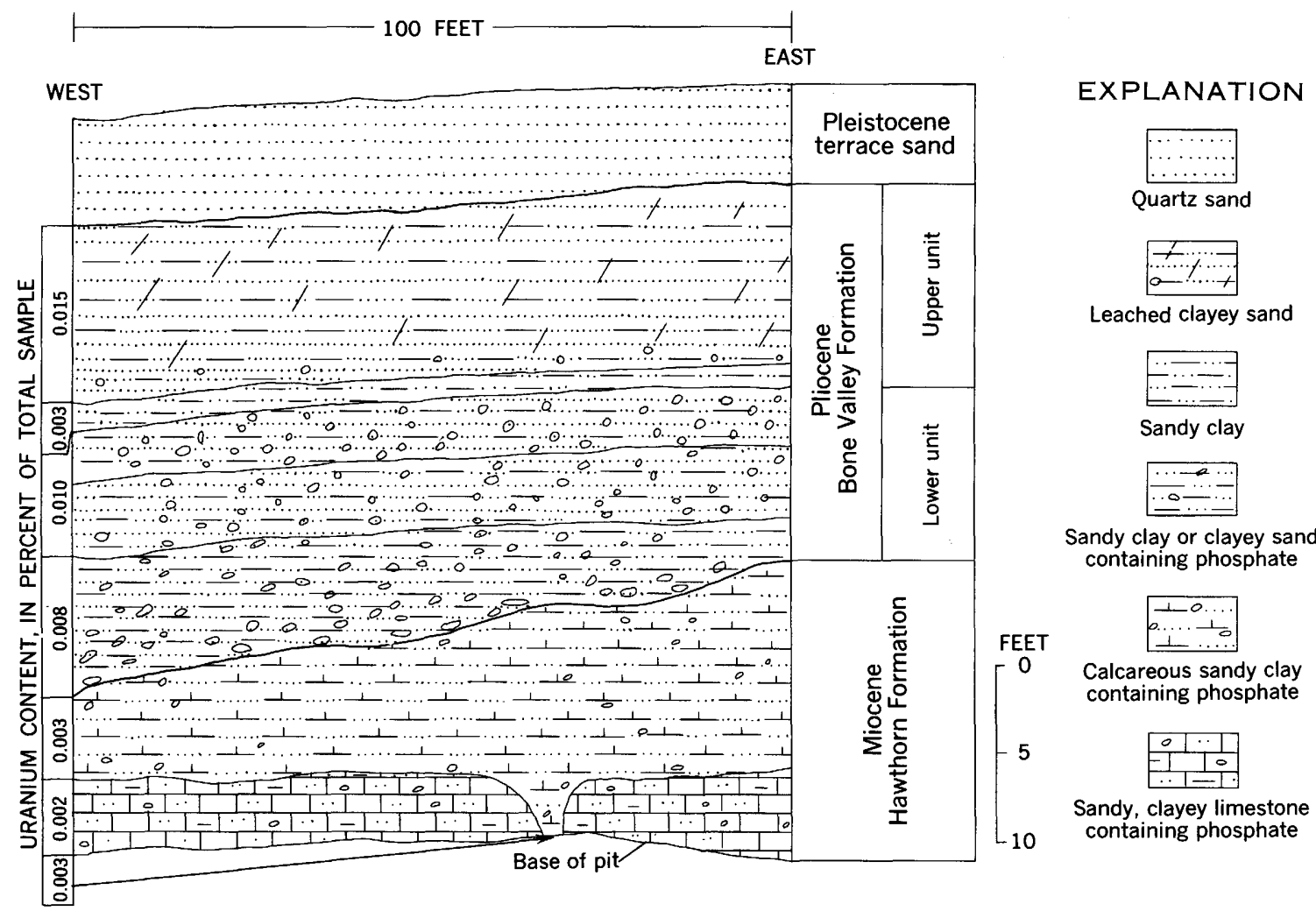

Figure 3.-Stratigraphic section, Watson mine, SE1/4 SE $1 / 4$ sec. 8 , T. 32 S., R. 25 E. Section measured by R. H. Stewart and H. M. Icke (U.S. Geol. Survey); uranium analyses by R. G. Milkey (U.S. Geol. Survey). 
are easily recognizable at all drill holes in the tract. The lower unit of the Bone Valley Formation is a light-gray, gray-white, light-graygreen, or light-gray-brown sand or slightly clayey sand containing coarse-sand- to granule-size dominantly black phosphate nodules. At the north end of the tract (section $A-A^{\prime}$, pl. 1, holes 12-14) the Bone Valley rests on the upper part of the Hawthorn, a dark-gray-green or yellow-green clayey sand containing abundant fine-grained phosphate. Clayey sand of the upper part pinches out to the south, as indicated between holes 11 and 12 on plate 1 (section $A-A^{\prime}$ ) and the Bone Valley rests on limestone or calcareous clay residual from limestone. The clay and limestone are cream, white, or yellow, and contain fine to very fine phosphate grains. The lithologic break is sharp and distinct in both places and is illustrated in logs F and G (p. 57 and 58).

At the Tilghman, Vandolah, and Little Charlie tracts the Bone Valley-Hawthorn contact is known only from drilling, but at all tracts the contact can be identified by the distinctive lithologies of the two formations.

\section{PLIOCENE SERIES}

\section{BONE VALIEY FORMATION}

The Bone Valley Formation was first called the Bone Valley gravel (Matson and Clapp, 1909; Sellards, 1910). It originally included all the minable phosphate plus the overlying clayey sand containing traces of phosphate, but it excluded the underlying hard limestone and the overlying loose sand. Sellards divided the formation $(1910$, p. 33) into a lower, phosphate-bearing member and an upper sand or sandstone member.

This division into a lower, phosphate unit and an upper, clayey sand unit is followed in this report, but because the lower part of the minable phosphate is in some places a residuum of the Hawthorn Formation, the lower unit of the Bone Valley Formation does not necessarily include all the minable phosphate.

\section{AGE AND FOSSILS}

The Bone Valley Formation has generally been regarded as either late Miocene or Pliocene in age (Cooke, 1945; Sellards, 1915; Matson, 1915). Bergendahl (1956) found that in De Soto County (south of the land-pebble district) the lower part of the Bone Valley interfingers with sands that contain fossils identified as late Miocene in age. Fossils are sparse in the Bone Valley, and as there are no natural outcrops, the only possible sources are mine pits and drill cuttings.

The lower minable part of the Bone Valley Formation at the Brewster mine contained vertebrate fossils that Sellards (1915) concluded were either late Miocene or early Pliocene in age. A more com- 
plete discussion of the fossils at the Brewster mine is in the report on the Chicora quadrangle (Cathcart, 1963c).

Vertebrate fossils were found at three localities at the No. 11 washer of the South Pierce mine and were identified by C. L. Gazin of the U.S. National Museum as follows:

NW1/4 NW1/4 sec. 5, T. 32 S., R. 24 E.

Nannippus minor (Sellards)

Neohipparion phosphorum (Simpson)

Prosthennops sp.

Mastodon

NE $1 / 4$ NW $1 / 4$ sec. 5 , T. 32 S., R. 24 E.

Nannippus minor

Neohipparion phosphorum

Vertebra and ear bone of a whale

Small tooth from an immature mastodon

SW1/4 SW1/4 sce. 32, T. 31 S., R. 24 E. (Iithologic $\log$ B, p. 52)

Nannippus minor

Cf. Teleoceras proterus

Prosthennops sp.

The horse teeth Neohipparion phosphorum and Nannippus minor are Pliocene, probably early Pliocene, according to Mrs. Jean Hough of the U.S. Geological Survey (written commun., 1951). The rhinoceros Teleoceras proterus is also a Plincene form. Prosthennops is a common Pliocene peccary. The mastodon and the whale were not identifiable.

A large avifauna, consisting of more than 200 bones, was collected from two localities at the No. 11 washer; one at the center of sec. 32, T. 31 S., R. 24 E., the other from the $\mathrm{N}_{1} / 2 \mathrm{NE}_{1} / 4 \mathrm{NW}^{1} / 4$ sec. 5 , T. $32 \mathrm{~S}$., R. 24 E. Eighteen bird species were identified from this, the largest Tertiary avifauna in this country (Brodkorb, 1955, p. 1). The species described are all extinct, and the age of the formation, on the basis of the avifauna, is probably middle or early Pliocene.

The age of the Bone Valley Formation in the Fort Meade quadrangle, on the basis of available fossil evidence, is Pliocene. To the south, as indicated by Bergendahl (1956), the lower part of the Bone Valley Formation may be late Miocene in age, but in the Fort Meade quadrangle no evidence of Miocene age has been found.

\section{PHYSICAI CHARACTERISTICS}

The lower unit of the Bone Valley Formation has somewhat different physical characteristics in the area adjacent to the Peace River than it does in the area of the higher flatwoods.

In the area adjacent to the Peace River it is a green and brown sandy clay to clayey sand. Driftrock is absent and beds of sand are scarce. The lower unit is bedded in exposures at the Watson mine. 
Phosphate particles are dominantly fine- to medium-sand size, but some are coarse. The particles are mostly white, but there are also brown and gray particles, and a very few black grains. Amber grains are common in the bottom half of the lower unit. Lithologic details of the lower unit in this area and typical sections are given in "Mine and Tract Descriptions."

In the higher flatwoods area the lower unit of the Bone Valley Formation is mostly sand or slightly clayey sand containing abundant coarse-sand- to granule-size black and brown phosphate nodules: Beds of driftrock are common, particularly near the base of the unit, and beds of clay are scarce. The lower unit is markedly crossbedded in some places at the No. 11 washer $(\log$ B, p. 52), and evidence of graded bedding is found in the log of drill hole $H$ (p. 59) at the Consolidated tract. Lithologic details of the lower unit in this area are given in the descriptions of the South Pierce mine and the Consolidated tract (p. 50 and 56 ).

The upper unit of the Bone Valley Formation is uniform throughout the Fort Meade quadrangle. In most drill holes in the area it is a white, gray, gray-brown, or gray-green clayey sand or sandy clay. Beds of clay or of sand are present but not abundant. Where leaching has been intense, the upper unit is a white or gray clayey sand that contains soft, white phosphate or aluminum phosphate-cemented sand (sandrock). Where the leaching is not so intense, or where leaching has not affected the rock, the unit is green gray, gray brown, or green and commonly contains small amounts of black, brown, or gray phosphate nodules.

Typical lithologies of the rocks of the upper unit are shown in logs $\mathrm{B}, \mathrm{C}, \mathrm{D}, \mathrm{F}, \mathrm{G}, \mathrm{H}$, and $\mathrm{K}$ and in the composite logs from the Vandolah and Little Charlie tracts.

\section{DISTRIBUTION AND THICKNESS}

The two units of the Bone Valley Formation are both present throughout the Fort Meade quadrangle, except along the courses of the modern streams where they have been removed by erosion (pl. 1).

The thickness of the lower unit ranges from 0 to about 50 feet (at a sinkhole in the NE1/4NE1/4 sec. 33, T. 31 S., R. 25 E.), and it probably averages $15-20$ feet.

The thickness of the upper unit ranges from 0 to about 30 feet. For much of the quadrange only the total thickness of the overburden has been recorded, and the upper unit of the Bone Valley Formation cannot be separated from sand of Pleistocene age. The maximum thickness of the overburden (pl. 4) is between 40 and 50 feet, and the upper unit probably does not exceed 40 feet in total thickness. The average thickness of the unit is probably between 10 and 15 feet. 


\section{STRATIGRAPHIC RELATIONS}

The contact of the upper and lower units of the Bone Valley Formation is conformable and gradational; its geologic relations are shown on section $A-A^{\prime}$ (pl. 1). At most of the drill holes plotted on this map the basal 2-4 feet of the upper unit contains some grains of phosphate, and the change from a trace of phosphate in the upper unit to the very abundant phosphate of the lower unit takes place in less than 1 foot.

The contact between the two units in unleached sections is drawn at the top of the potentially economic phosphate deposit. The economic contact may be below the stratigraphic contact where leaching has extended down into the lower unit. For example, at hole 4 on section $B-B^{\prime}$ (pl. 1), the top 8 feet of the lower unit has been leached so thoroughly that this part of the lower unit was placed in the aluminum phosphate zone, and the economic contact is 8 feet below the stratigraphic contact.

The upper unit of the Bone Valley Formation is much thicker and more persistent in the high flatwoods (section $A-A^{\prime}$, pl. 1) than in the low flatwoods and valley (section $B-B^{\prime}$, pl. 1 ).

The contact of the upper unit of the Bone Valley Formation with the overlying sand of Pleistocene age is placed at the lithologic break between clayey sand and the overlying unconsolidated sand. At the few places where the contact is well exposed, it is irregular in form and apparently disconformable. The geologic relations of the sand of Pleistocene age (section $B-B^{\prime}$, pl. 1) also indicate that the contact is disconformable. In stream channels (hole 3 ) sand of Pleistocene age rests on the Hawthorn Formation; close to the streams (holes 4,6) Pleistocene sand rests on the lower unit of the Bone Valley Formation; elsewhere the sand of Pleistocene age rests on the upper unit of the Bone Valley.

Channels filled with sand cut through the Bone Valley Formation. One such channel, shown in figure 4, cuts through Pleistocene sand and both units of the Bone Valley Formation. Probably the channel fill is a late Pleistocene or Recent deposit, and the sand underlying the channel fill is probably a marine-terrace deposit of earlier Pleistocene age.

\section{PLEISTOCENE SERIES}

\section{TERRACE DEPOSTTS}

A blanket deposit of fine to medium, well-sorted quartz sand entirely covers the Fort Meade quadrangle except along the Peace River, where older rocks are exposed. The top 1-2 feet of the sand is commonly stained black by organic material, and limonite-cemented sand (hardpan) is present in the section (fig. 17). The iron cement is secondary, 

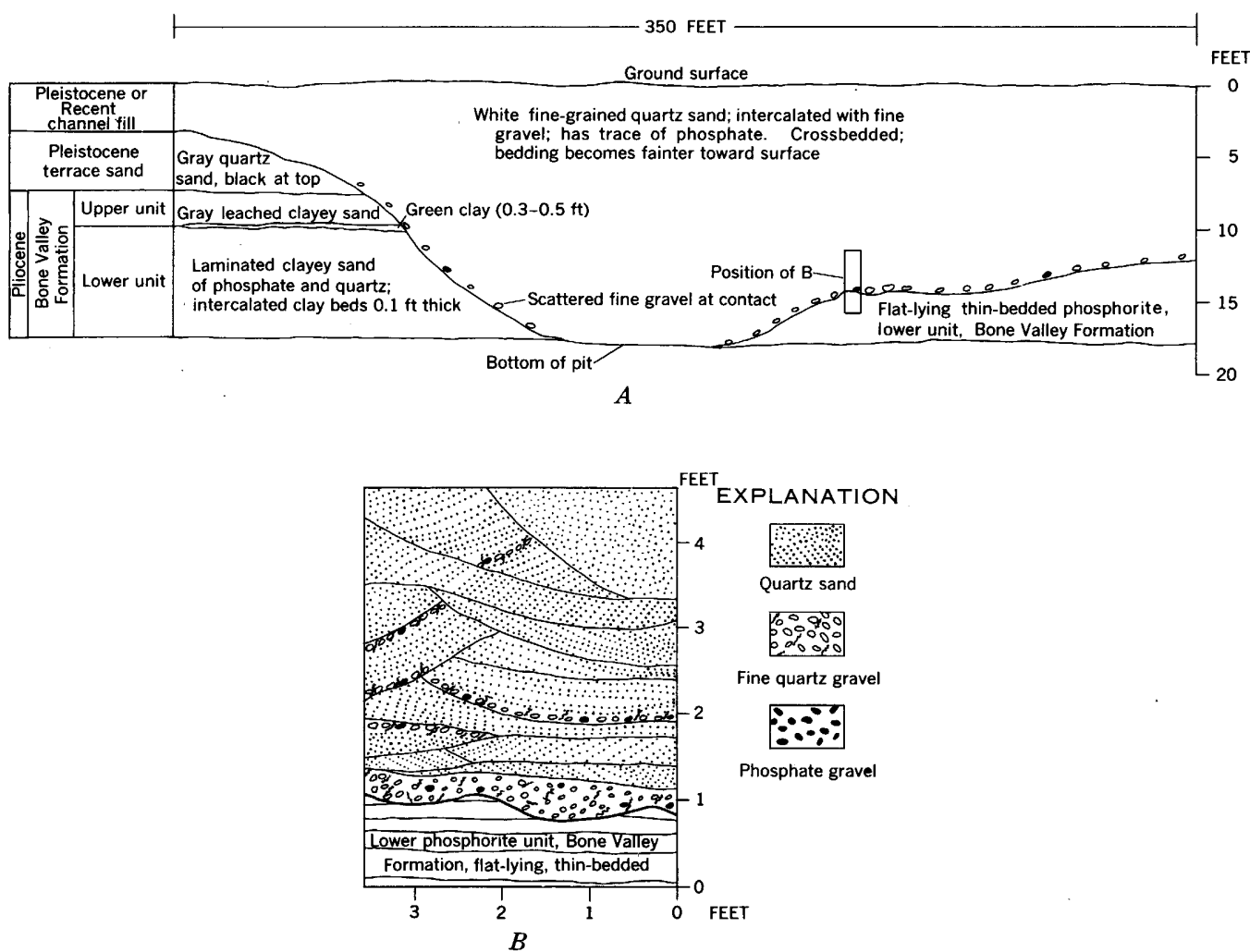

Figure 4.-Channel at the Watson mine, NE $1 / 4 \mathrm{SW} 1 / 4$ sec. 9 , T. 32 S., R. 25 E. $A$, General stratigraphic relations (from sketch by F. N. Houser, U.S. Geol. Survey). B, Detailed sketch of crossbedding and contact relations. 
and clayey sand close to the surface in the top part of the upper unit of the Bone Valley Formation may be cemented by iron oxide.

Two of the Pleistocene shorelines of MacNeil (1950) are represented in the Fort Meade quadrangle: the 100-foot Wicomico and the 150foot Okefenokee. The 150-foot shoreline is represented in the northcentral part of the quadrangle, and the 100 -foot shoreline is probably present in the southwest corner of the quadrangle. The 100-foot contour line along the Peace River and its tributaries (fig. 2) is the result of erosion by these streams; it is not a part of the 100 -foot shoreline.

No fossils were found in the terrace sand in the Fort Meade quadrangle, but fossil teeth were found in surficial sand (in deposits of the Wicomico shoreline) in about the center of sec. 9, T. 36 S., R. 24 E., to the south of the quadrangle. The teeth were identified by G. Edward Lewis of the U.S. Geological Survey (written commun., 1954) as Equus sp. and probably Bison sp., and are a Pleistocene assemblage, possibly of later age than early Pleistocene.

No attempt was made to differentiate the deposits of the different Pleistocene shorelines. Davidson (1952) suggested that the deposits at higher elevations are better sorted and coarser than the deposits at lower elevations. The evidence, however, is not conclusive, because all the samples are well sorted and most are fine grained.

The marine deposit of terrace sand and the fluvial deposit of the channel filling shown in figure 4 are distinctly different. The channel deposit contains abundant gravel and is not as well sorted as the fine sand of the terrace deposit. This is one of the few places where deposits of Pleistocene age can be separated; at most places in the land pebble district, particularly where only drill-hole data are available, the Pleistocene deposits are treated as a unit.

\section{RECENT DEPOSITS}

\section{RIVER-PEBBLE DEPOSITS}

Phosphate sand and fine gravel deposited as bars and in the flood plains of the present-day streams are called river-pebble deposits. River-pebble deposits contain no clay and only small amounts of quartz sand. They were mined along the Peace River from 1888 to about 1908; one mine may have been in the Fort Meade quadrangle near the town of Bowling Green (Eldridge, 1893, p. 197). Most mining of river-pebble deposits along the Peace River was south of Arcadia almost to the mouth of the river.

\section{OTHER RECENT DEPOSITS}

Windblown sand, muck, and peat at the surface are classified as Recent. The deposits are very thin and erratic in distribution, and they 
have not been separated. The channel fill at the Watson mine (fig. 4) may also be Recent in age.

\section{STRUCTURE}

The Fort Meade quadrangle is a part of the East Gulf Coastal Plain, and the basic structure is a simple regional dip to the south away from the Ocala uplift. The regional dip is measured in feet per mile, and steep dips are unknown.

Small local structures such as the one described in the Plant City quadrangle (Cathcart, 1963b) are probably present. The distribution of the upper part of the Hawthorn Formation in the quadrangle may be structurally controlled. The upper part is present only in the northwestern part of the Fort Meade quadrangle, is thicker and more persistent to the southwest in the Chicora quadrangle (Cathcart, $1963 \mathrm{c}$ ), and is thin or absent to the northwest in the Keysville and Plant City quadrangles (Cathcart, 1963a, b). The upper part probably was preserved in the northwestern part of the Fort Meade quadrangle because it is in a structural low but is absent to the south as a consequence of erosion on a local structural high.

\section{MINERAL COMPOSITION}

The mineral composition of the exposed rocks, or of the rocks penetrated by drilling in the Fort Meade quadrangle, is basically simple. There is however, a considerable difference between the composition of weathered and unweathered rocks.

The lower part of the Hawthorn Formation contains quartz, calcite, dolomite (in the near-surface parts of the formation), a clay mineral (montmorillonite mostly, although attapulgite has been reported (Berman, 1953)) and pellets, grains, and nodules of carbonatefluorapatite (Altschuler and others, 1952). Weathering of the lower part of the Hawthorn Formation forms a calcareous clay, the so-called bedclay. The mineral composition of this material is the same as that of the unweathered material-only the relative amounts of the minerals are changed. Quartz, apatite, and montmorillonite are much more abundant, whereas calcite and dolomite are much less abundant, and in a few samples are absent. Chemical analyses and the mineral composition of bedclay are shown in table 3 (sample 609-26-3), and the lithology of the sample is shown in the log of drill hole $\mathrm{A}$.

The upper and lower units of the Bone Valley Formation and the upper part of the Hawthorn Formation, where they are not weathered, contain the same minerals - quartz, carbonate-fluorapatite, and montmorillonite-although the proportions of these minerals vary. For 
TABLE 3.-Analytical and mineralogic data from drill hole in sec. 9, T. 32 S., R. $26 \mathrm{E}$.

[Uranium analyses by Frank Cuttita; other chemical analyses by F. S. Grimaldi; mineralogy by $\dot{Z}$. s. Altschuler and C. E. Boudreau (U.S. Geol. Survey)]

\begin{tabular}{|c|c|c|c|c|c|c|c|c|}
\hline \multirow{2}{*}{$\begin{array}{l}\text { Lab. } \\
\text { No. }\end{array}$} & \multirow{2}{*}{$\begin{array}{l}\text { Field } \\
\text { No. }\end{array}$} & \multicolumn{6}{|c|}{ Analyses in percent } & \multirow{2}{*}{ Mineral composition 1} \\
\hline & & $\mathrm{P}_{2} \mathrm{O}_{5}$ & $\mathrm{CaO}$ & MgO & $\mathrm{Al}_{2} \mathrm{O}_{3}$ & $\mathrm{Fe}_{2} \mathrm{O}_{3}$ & $\mathbf{U}$ & \\
\hline 943 & $\begin{array}{l}609-26-1 \\
609-26-2\end{array}$ & $\begin{array}{l}18.8 \\
20.7\end{array}$ & $\begin{array}{l}33.7 \\
31.9\end{array}$ & $\begin{array}{r}0.27 \\
.18\end{array}$ & $\begin{array}{l}2.5 \\
3.3\end{array}$ & $\begin{array}{r}0.6 \\
.6\end{array}$ & $\begin{array}{r}0.030 \\
.007\end{array}$ & $\begin{array}{l}\text { Quartz, phosphate, kaolinite. } \\
\text { Quartz, phosphate, montmoril- }\end{array}$ \\
\hline $945 \ldots$ & $609-26-3$ & 8.4 & 17.1 & 2.44 & 4.6 & 2.4 & .006 & $\begin{array}{l}\text { Quartz, montmorillonite, calcite, } \\
\text { dolomite, phosphate. }\end{array}$ \\
\hline
\end{tabular}

1 The minerals are listed in the approximate order of their abundance. The phosphate mineral was not Identified, but is probably apatite, except in the top sample, where an aluminum phosphate mineral, probably crandallite, may be present in addition to apatite.

Log A.-Drill hole in SW1/4SE1/4 sec. 9, T. $32 S ., R .26$ E.

[Adapted from lithologic $\log$ by L. J. Kosofsky, U.S. Geol. Survey. Drilling by Tennessee Valley Authority]

Pleistocene :

Terrace sand:

Sand, loose, black to dark-gray, carbonaceous

Sand, loose, white, fine

Sand, loose, brown to dark-reddish-brown iron-stained, medium

to fine

Total terrace sand

Pliocene :

Bone Valley Formation (lower unit) :

Clay, sandy, gray; 20-25 percent coarse-sand- to granule-size white and some brown and black phosphate nodules. Sample 609-26-1 (table 3)

Clay, sandy, blue-gray ; 20-30 percent coarse-sand- to granule-size

black and brown phosphate nodules. Sample 609-26-2 (table 3)

Total Bone Valley Formation

Miocene :

Hawthorn Formation:

Clay, sandy, calcareous, light-gray ; $2-3$ percent fine- to mediumsand-size phosphate grains. Sample 609-26-3 (table 3)

Clay, very calcareous, sandy ; minor amounts of fine black phosphate grains, and abundant limestone fragments

Limestone, soft, white, sandy ; trace of very fine black phosphate grains

Part of Hawthorn Formation

Bottomed on hard limestone of the Hawthorn Formation. 
example, the lower unit of the Bone Valley Formation is characterized by abundant apatite (sample 609-26-2, table 3), whereas the upper unit contains only a small amount of apatite.

The surficial sand consists mostly of clear quartz grains, although iron oxide is present as a stain or cement and carbonaceous material commonly stains the sand black in the top few inches.

The mineral composition of a section of weathered material at the South Pierce mine is presented in $\log E$ (p. 56). The samples were screened at 200 mesh, and the material that passed through the screen was analyzed in the X-ray diffractometer by L. V. Blade of the Geological Survey. In the top sample, wavellite (aluminum phosphate) is the most abundant phosphate mineral and kaolinite is the clay mineral. Deeper in the section, both crandallite (calcium aluminum phosphate) and wavellite are present, and just above the unweathered material, apatite and montmorillonite are present in small amounts. Quartz is present in all samples. The mineralogy of the aluminum phosphate zone-the weathered material-has been presented in detail by Altschuler and colleagues $(1956,1958)$.

\section{WEATHERING AND EROSION}

At least two periods of weathering altered the phosphatic sedimentary rocks of the Fort Meade quadrangle and played a major role in the formation of the economic calcium phosphate zone. The first occurred after the deposition of the Hawthorn Formation. Weathering was largely chemical and resulted in the leaching of the carbonate from the calcareous part of the formation, which left a residuum of quartz, phosphate, and clay. Erosion removed most of the upper part of the Hawthorn Formation prior to the deposition of the Bone Valley Formation, though a few erosional remnants of the upper part of the formation still remain. Much of the residual material left on the Hawthorn surface was reworked into the lower unit of the Bone Valley, and sinkholes formed on the surface of the Hawthorn are filled with phosphate of the lower unit of the Bone Valley Formation.

Intense lateritic weathering (Altschuler and others, 1958) followed the deposition of the Bone Valley Formation and caused the alteration of apatite to aluminum phosphate minerals and alteration of montmorillonite to kaolinite.

The intensity of the alteration was not constant. Alteration was more intense in the area of the Watson tract, in the low flatwoods adjacent to the Peace River, than in the Consolidated tract, in the high flatwoods and ridge (fig. 11, lower).

The weathering was accomplished by downward percolating acid ground waters, and the alteration stopped at the water table or at 
impervious clay beds. Therefore, the part of the stratigraphic section that was altered is different at different places in the quadrangle. All or part of the upper unit of the Bone Valley Formation was altered, and in places the alteration continued down into the top part of the lower unit of the Bone Valley Formation. The lower part of the Hawthorn Formation was also altered at this time, chiefly by removal of carbonate to leave behind the calcareous, phosphatic sandy clay, called bedclay. The alteration of montmorillonite to kaolinite releases $\mathrm{MgO}$ (Cathcart, 1963a), and the dolomitization of the top of the limestone of the Hawthorn Formation probably took place during this weathering period.

At the localities of $\operatorname{logs} B$ and $F$ the alteration to the aluminum phosphate zone stopped in the upper unit of the Bone Valley Formation. At both of these localities, the basal bed of the upper unit contains trace amounts of fresh shiny black phosphate grains.

At the localities of $\operatorname{logs} \mathrm{D}$ and $\mathrm{H}$ the zone of leaching extends to the contact between the upper and lower units of the Bone Valley Formation. At both of these drill holes, the basal bed of the upper unit of the Valley Formation contains soft, dull, white phosphate grains. The formation of soft, white phosphate is the first step in the leaching process (Altschuler and others, 1956). The top part of the lower unit at drill hole $\mathrm{D}$ contains some white phosphate nodules; this indicates that leaching extended into the lower unit. The bed, however, is considered a part of the matrix and is put into the calcium phosphate zone. At drill hole $\mathrm{H}$ soft, white phosphate is most abundant at the contact of the upper and lower units. The basal bed of the aluminum phosphate zone may be the leached lower unit instead of the upper unit. At both of these drill holes, the contact between the upper and lower units was selected on the basis of economics.

Ar drill hole $J$ leaching has extended down into the lower unit of the Bone Valley Formation (fig. 5). All the upper unit of the Bone Valley Formation contains wavellite cement, and the top bed of the lower unit contains abundant soft, white phosphate and wavellitic clay.

Vertical distribution of uranium in the section is shown by the gamma-ray log (fig. 5). The very sharp rise in radioactivity at the base of the aluminum phosphate zone is in the thin beds of sandrock and soft, white phosphate, whereas radioactivity is only slightly above the background level in the upper bed of sandrock at the top of the aluminum phosphate zone. Uranium, leached from the upper part of the section, is concentrated in the base of the aluminum phosphate zone. The top bed of the calcium phosphate zone is low in radioactivity, a reflection of the small number of phosphate nodules in this 


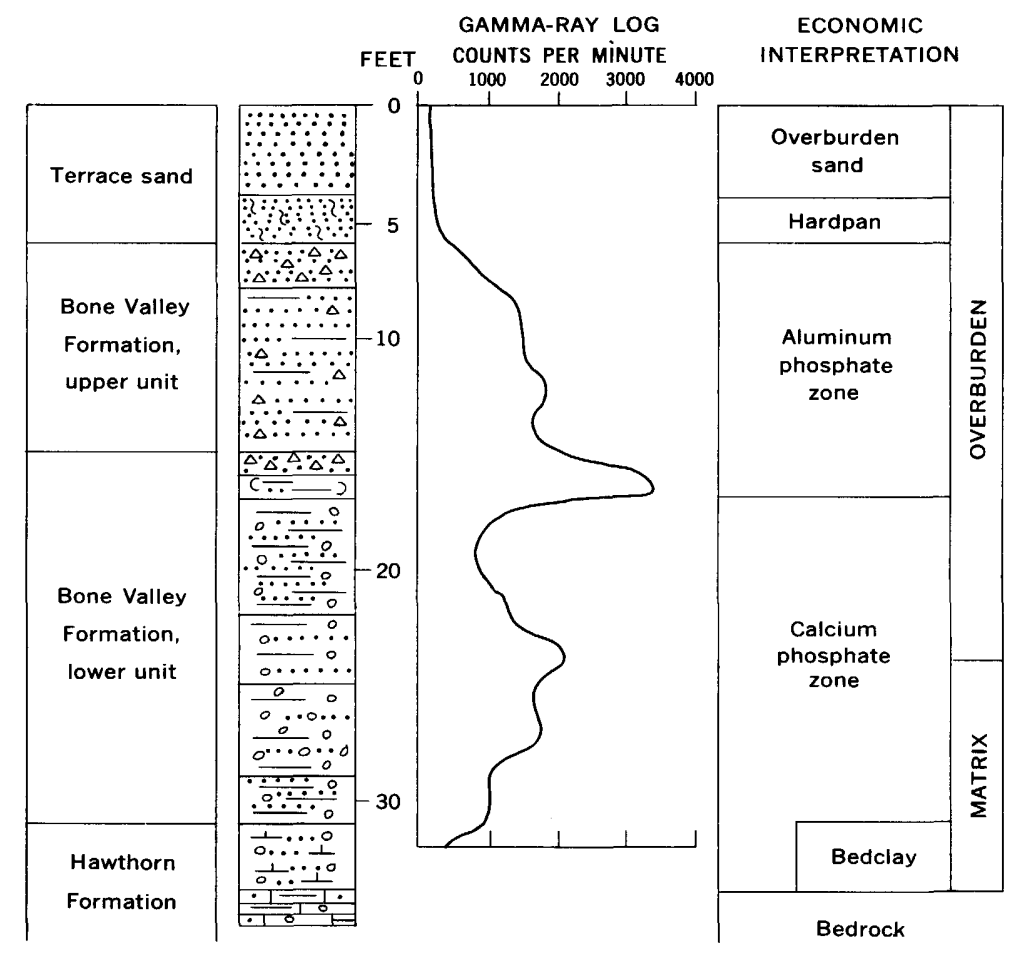

\section{EXPLANATION}



Quartz sand

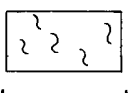

Iron cement

$$
\begin{array}{lll}
\Delta & \Delta & \Delta \\
\Delta & \Delta & \Delta
\end{array}
$$

Aluminum phosphate cement

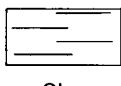

Clay

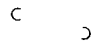

$$
\begin{array}{|lll|}
\hline & 0 & 0 \\
0 & 0 & 0 \\
0 & & 0 \\
\hline
\end{array}
$$

Leached, soft, white phosphate nodules

Phosphate nodules

$$
\begin{aligned}
& 1 \pm \perp \\
& \perp \pm \perp \\
& \hline
\end{aligned}
$$

Calcareous clay

$$
\text { Limestone }
$$

FraURE 5.-Log of drill hole in SE1/4NE1/4 sec. 34, T. 32 S., R. 24 E. (see $\log$ J, p. 66) showing lithology and economic geology. 
bed; the rise in radioactivity in the bottom beds of the calcium phosphate zone reflects the increase in the number of phosphate nodules. The radioactivity drops off sharply in the calcareous bedclay of the Hawthorn Formation.

Lateral distribution of the aluminum phosphate zone at the Vandolah tract is shown on plate 1 (section $D-D^{\prime}$ ). The aluminum phosphate zone was penetrated by each drill hole in the section, but the thickness and the stratigraphic position differ from hole to hole. Also a variety of profiles is shown in the gamma-ray logs. At most of the holes, the radioactivity reaches a maximum at or close to the base of the leaching, but at some there are double radiation peaks, and at hole 6 the radiation peak is in about the middle of the upper unit of the Bone Valley Formation. The zone is missing along presentday streams, as shown on plate 1 (section $B-B^{\prime}$, holes 3,6 ).

Material from the aluminum phosphate zone was eroded and redeposited in some areas. At the locality of drill hole $\mathrm{K}$, the upper unit of the Bone Valley Formation consists of clayey sand and sandy clay containing some soft, white phosphate nodules. A rubble zone consisting of boulders of aluminum phosphate-cemented sand and boulders that contain abundant soft, white phosphate nodules is present about a foot above the base of the sand of Pleistocene age. The material in the rubble zone is unlike that of the underlying leached upper unit of the Bone Valley Formation and was eroded from a section of thoroughly leached material, transported, and deposited at the locality of drill hole $\mathrm{K}$.

A Pleistocene soil profile (Hunt and Hunt, 1957) is superimposed on or overlies the aluminum phosphate zone. This profile is typified by the Leon soil (Fowler and others, 1927) and consists of a surface zone of gray leached sand underlain by iron-stained or iron-cemented sand (hardpan) and then by clayey sand. Hardpan is usually within the sand of Pleistocene age, but as shown in figure 5 it may be at the contact between the loose sand of Pleistocene age and the sandrock of the upper unit of the Bone Valley Formation. The distribution of the hardpan is controlled to some extent by the surface topography (see fig. 17: hardpan confined to the ridge area) and is mostly at elevations above 100 feet.

A very young soil profile has, according to Hunt and Hunt (1957, p. 799), "developed on deposits containing pottery, which was first introduced into this region shortly before the beginning of the Christian era." This soil profile is difficult to distinguish in areas where only drill-hole data are available. 


\section{ECONOMIC GEOLOGY}

The only mineral mined in the Fort Meade quadrangle is phosphate rock, obtained from both river-pebble and land-pebble types of deposits. The records of the mining of the river-pebble deposits are obscure, and very little is known of the history of this type of mining. The records of the mining of the land-pebble type of material are much more complete.

\section{HISTORY OF MINING}

River-pebble deposits.-The first mining for phosphate in Florida was for the so-called river-pebble material, which was found in river bars and flood plains and was mined by dredging along the Peace River. The earliest record of the mining of this material in the Fort Meade quadrangle is dated 1892. On the map in his report, Eldridge $(1893$, p. 197) showed the location of a river-pebble mine on the Peace River, at or near the present town of Zolfo Springs, at the south edge of the quadrangle. Records of the mining could not be found; however, it is known that by 1908 (Sellards, 1909, map, pl. XII) there was no mining at this location. Most of the river-pebble mines are to the south of the quadrangle, the southernmost at Punta Gorda, at the mouth of the Peace River.

Land-pebble deposits-The earliest record of the mining of the landpebble rock in the Fort Meade quadrangle was also written in 1892 (Eldridge, 1893, map, p. 197). One of the mines in the land-pebble field located on Eldridge's map is on the Peace River, probably in sec. 21, T. 32 S., R. 25 E., and may be the latter-day Jane Jay mine of the International Phosphate Co. The Jane Jay mine was active in 1908 (Sellards, 1909, map, pl. XII) and produced some phosphate as late as 1920 (Gunter, 1922).

By 1908 the Tilghman Phosphate Co. was also operating in the Fort Meade quadrangle at a locality in T. 24 S., R. 24 E. Its mine is in Polk County, just to the north of the Hardee County line, and is the southernmost in the district. Tilghman became the Independent Chemical Co. and continued mining through the mid-1920's at various places on the so-called Tilghman tract.

In 1911 the Amalgamated Phosphate Co., predecessor to the American Cyanamid Co., was mining its Brewster tract in the northwest corner of the quadrangle, and it continued mining there until 1937 (J. L. Weaver, written commun., 1961).

The American Agricultural Chemical Co. mined in the northwestern part of the quadrangle for many years at the Nos. 11 and 12 mines of its South Pierce area. 
Swift \& Co. mined in two areas in the northern part of the Fort Meade quadrangle. According to Mr. H. M. Larsen of Swift \& Co. (written commun., 1961), the Waldo mine in the northernmost part of the quadrangle was mined from 1925 to 1937 , and the Watson mine, just south of the Waldo, began operation in 1937 and was still in operation in 1964.

\section{CALCIUM PHOSPHATE ZONE}

The calcium phosphate zone of the land-pebble phosphate district comprises unconsolidated sandy clay, ćlayey sand, or sand and is characterized by abundant rounded particles of calcium phosphate. The zone overlies hard limestone or dolomite (bedrock or basement rock) of the Hawthorn Formation and is overlain by the aluminum phosphate zone. The calcium phosphate zone is potentially minable and includes the minable material-matrix-although it is not completely equivalent to it. The limestone bedrock contains calcium phosphate nodules, but it is not included in the calcium phosphate zone because the material is not potentially economic. The practical problems of mining and processing the phosphatic limestone have not been studied by the phosphate companies.

\section{STRATIGRAPHIC RELATIONS}

The calcium phosphate zone includes rocks of the lower unit of the Bone Valley Formation and the upper and lower parts of the Hawthorn Formation (section $C-C^{\prime}$, pl. 1). At holes 1 and 2 (section $C-C^{\prime}$, pl. 1) the calcium phosphate zone includes the lower unit of the Bone Valley Formation and the upper part of the Hawthorn Formation. At hole 3 the zone includes the lower unit of the Bone Valley and both parts of the Hawthorn Formation. At hole 4 the lower unit of the Bone Valley is leached and the calcium phosphate zone is entirely within the two parts of the Hawthorn. At hole 5 the zone includes the lower unit of the Bone Valley and residual clay of the lower part of the Hawthorn, and at hole 6 the calcium phosphate zone is entirely within the lower unit of the Bone Valley Formation.

The relations between the calcium phosphate zone and the matrix are also shown on plate 1 (section $C-C^{\prime}$ ). The calcium phosphate zone is entirely matrix at holes 1,4 , and 6 , but the lower part of the zone is not considered to be matrix at the other localities either because it is too low in grade, tonnage, or both.

At holes 2, 3, 5, and 6 the matrix is entirely within the lower unit of the Bone Valley Formation, but at hole 5 the lower part of the lower unit of the Bone Valley is not considered to be a part of the matrix. At hole 1 most of the matrix is in the upper part of the 
Hawthorn Formation, and at hole 4 most of the matrix is in the residuum of limestone-the lower part of the Hawthorn Formation.

\section{DISTRIBUTION AND THICKNESS}

The calcium phosphate zone underlies the entire Fort Meade quadrangle, except along the courses of present-day streams, where it has been removed by erosion (pl. 3). Most of T. $33 \mathrm{~S}$. and the north half of T. $34 \mathrm{~S}$. is blank on the map because of lack of data. This area is probably underlain by a calcium phosphate zone, because average, or slightly more than average, thicknesses of the zone are known to be present both to the north and to the south.

The calcium phosphate zone ranges in thickness from zero along the stream courses to about 50 feet in the NE1/4 sec. 33, T. 31 S., R. $25 \mathrm{E}$., at the north edge of the quadrangle. The average thickness of the zone in the quadrangle is difficult to estimate because data for a large area are lacking, but it is probably between 10 and 15 feet.

\section{ECONOMIC FACTORS}

The factors determining whether the calcium phosphate zone is minable have been discussed previously (Cathcart and McGreevy, 1959, p. 240). These factors, briefly recapitulated, are:

1. The matrix must be at least 3 feet thick to be mined with the large equipment used.

2. The thickness of waste material that can be removed is a function of the digging depth of the dragline to be used. If the total thickness is too great, a bench must be cut for the dragline, thereby creating an additional expense. The total number of cubic yards of waste material moved (overburden plus the sand tails and slime of the matrix) per long ton of product to be recovered must be below a certain maximum, which ranges from 20 to 27 cubic yards per ton.

3. The lowest grade material considered as reserves is about 66 percent BPL $\left(=30.2\right.$ percent $\left.\mathrm{P}_{2} \mathrm{O}_{5}\right)$.

4. The recoverable phosphate products must be greater than about 400 long tons per acre foot.

5. More than 5 percent ferric oxide and aluminum oxide, reported together as percent $\mathrm{I}$ and $\mathrm{A}\left(\mathrm{Fe}_{2} \mathrm{O}_{3}+\mathrm{Al}_{2} \mathrm{O}_{3}\right)$, would probably make a deposit uneconomic.

\section{REAATION TO THE SURFACE OF THE HAWTHORN FORMATION}

The relation of the calcium phosphate zone to the surface of the Hawthorn Formation is not simple and clear cut, but, in general, a thick calcium phosphate zone tends to fill sinkholes or depressions on 
the surface of the Hawthorn, and a thin calcium phosphate zone tends to overlie highs on the Hawthorn surface. For example:

1. In sec. 33, T. 31 S., R. 25 E., more than 50 feet of calcium phosphate zone fills a sinkhole on the Hawthorn surface.

2. In sec. 1, T. 32 S., R. 24 E., a thin calcium phosphate zone overlies a high on the Hawthorn.

3. In sec. 6, T. 32 S., R. 25 E., a thick calcium phosphate zone fills a low area on the Hawthorn surface.

4. In sec. 6, T. 32 S., R. 26 E., over a Hawthorn ridge, the calcium phosphate zone is less than 10 feet thick, and just to the south the zone is more than 30 feet thick and overlies a depression on the Hawthorn surface.

5. In secs. 1 and 2, T. 32 S., R. 23 E., 40 feet of calcium phosphate zone fills a depression on the Hawthorn surface, whereas to the east and north the zone is less than 1 foot thick and overlies highs on the Hawthorn surface.

6. In secs. 16 and 21 , T. 34 S., R. 24 E., more than 20 feet of calcium phosphate zone overlies lows on the Hawthorn surface.

Some exceptions should also be cited. For example, in sec. 34, T. 32 S., R. 24 E., an irregular 10-foot contour on the calcium phosphate zone is superposed on both high and low areas on the surface of the Hawthorn, and in sec. 33, T. 32 S., R. 24 E., a calcium phosphate zone more than 20 feet thick overlies both a low and a high on the Hawthorn surface.

Where the calcium phosphate zone is more than 20 feet thick it generally overlies or fills depressions on the Hawthorn surface, but where it is 10 feet or less thick it may overlie highs or lows on the Hawthorn.

\section{RELATION TO THE OVERBURDEN}

The overburden ( $p l .4$ ) consists of quartz sand of Pleistocene age, clayey sand of the upper unit of the Bone Valley Formation, and the aluminum phosphate zone. The overburden ranges in thickness from zero (along the Peace River) to more than 50 feet (in the NE1/4 NW1/4 sec. 3, T. 32 S., R. 25 E.) and averages about 25 feet. The overburden is less than 10 feet thick along all the present-day streams and has been removed along the course of the Peace River.

The overburden and the calcium phosphate zone are similar in general distribution (compare pls. 3 and 4 ) in that both are thick under the interstream divides and thin toward present-day streams. Except for this general pattern the distribution of the two units does not match closely. The thicker parts of the two zones are not consistently related, nor is there a tendency for thicker overburden to overlie thinner calcium phosphate zone. 


\section{SIzE VARIATIONS OF PHOSPHATE NODULES}

Phosphate nodules in the land-pebble phosphate deposits are divided into two size classes for economic purposes: pebble (+14 mesh), and concentrate $(-14+150$ mesh). Cathcart and Davidson (1952) pointed out that the variation in phosphate particle size is mappable and is related both to present and to Hawthorn topography.

The distribution of coarse and fine phosphate in the Fort Meade quadrangle is shown by the ratio of the tonnage of the coarse $(+14$ mesh) phosphate particles to the tonnage of the fine $(-14+150$ mesh) (fig. 6). Fine phosphate predominates in the area of the low flatwoods adjacent to the Peace River and in the south half of T. 34 S., where the topography is subdued; most of the remainder of the quadrangle contains deposits of phosphate that are predominantly coarse grained.

Phosphate particles are coarse and low in $\mathrm{P}_{2} \mathrm{O}_{5}$ content in the river valleys. This material is the river pebble, at least along the Peace River. Fine-grained phosphate was probably removed by the sorting action of the river, and some of the $\mathrm{P}_{2} \mathrm{O}_{5}$ content of the coarse nodules was leached by acid ground water.

\section{ANALYTICAL DATA}

Analytical data for the calcium phosphate zone (table 4) are of samples taken in a drilling program by the phosphate companies under contract to the Atomic Energy Commission. A single sample, including the entire calcium phosphate zone, was taken at each drill hole. The sample was screened, and flotation was used to separate fine phosphate and quartz. Samples were analyzed only for the oxides shown. Phosphate was reported as percent BPL; percent $\mathrm{P}_{2} \mathrm{O}_{5}$ was computed from percent BPL by the author.

The coarse nodules (pebble) contain less $\mathrm{P}_{2} \mathrm{O}_{5}$ and more $\mathrm{U}_{3} \mathrm{O}_{8}$ and acid insoluble than do the fine nodules (concentrate). The samples from R. 24 E. contain less $\mathrm{P}_{2} \mathrm{O}_{5}$ and more $\mathrm{U}_{3} \mathrm{O}_{8}$ than do the samples from R. 25 E., and the differences, though small, are significant; the phosphate deposits in R. $24 \mathrm{E}$. contain much more pebble than concentrate, but the deposits in R. 25 E. contain more concentrate than pebble. The $\mathrm{Fe}_{2} \mathrm{O}_{3}+\mathrm{Al}_{2} \mathrm{O}_{3}$ content is relatively uniform, but in the samples from T. 32 \$., R. 25 E., it is slightly higher in the coarse phosphate than in the fine phosphate.

The reversal of the general trend of higher $\mathrm{P}_{2} \mathrm{O}_{5}$ and lower insoluble content with decreasing grain size in the $-14+16$ mesh fraction of samples from T. 32 S., R. 25 E., is due to the presence of quartz sand grains in the fraction. The +14 mesh fraction contains almost no free quartz sand. The quartz sand in the $-16+150$ mesh fraction is re- 


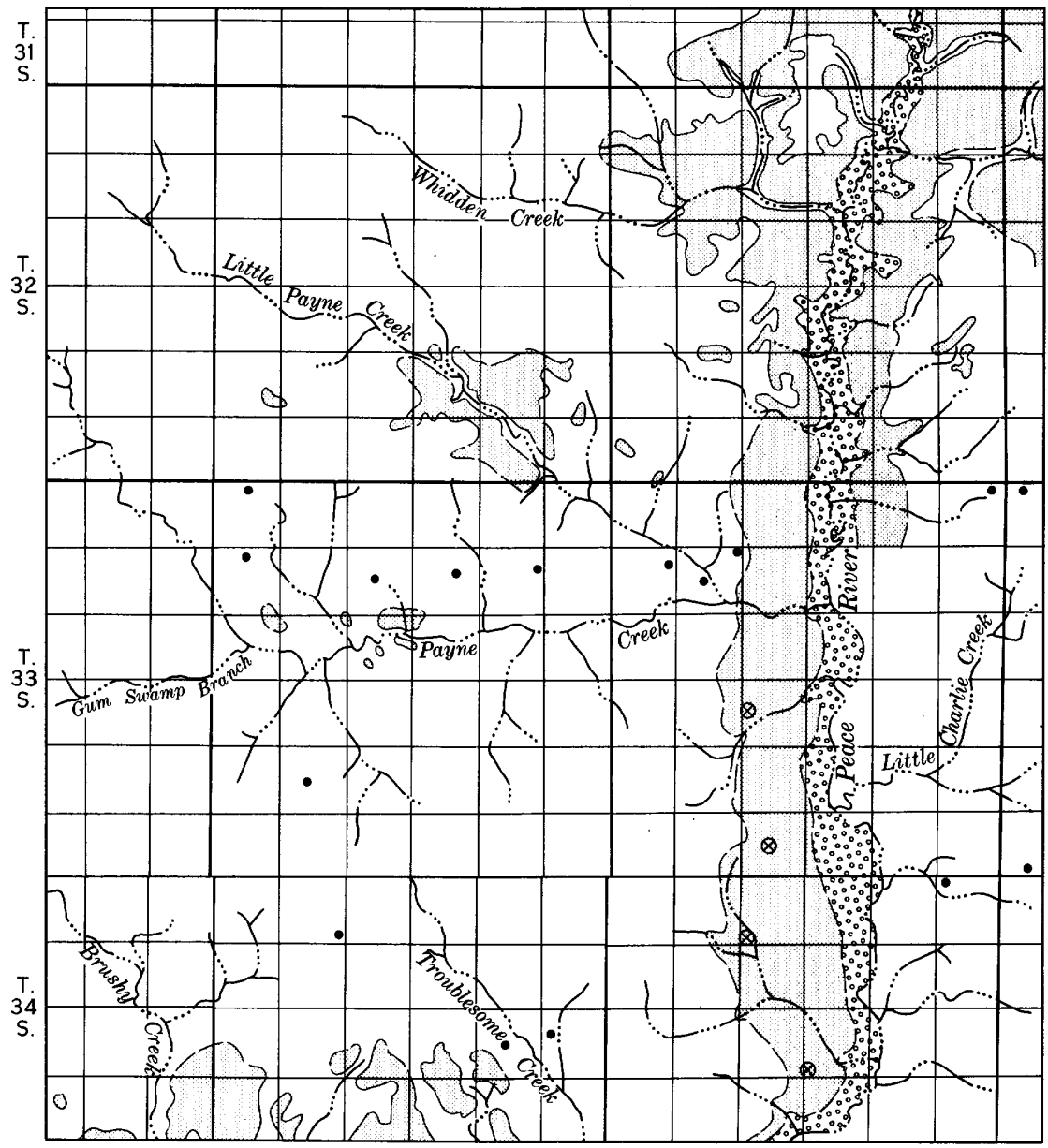

\begin{tabular}{lllllll}
1 & 2 & 3 & 4 & 5 & 6 MILES \\
\hline & 1 & 1 & 1 & 1 & 1
\end{tabular}

Figure 6.-Distribution of the phosphate products (pebble, +14 mesh; concentrate, $-14+150$ mesh) of the calcium phosphate zone, Fort Meade quadrangle, Florida. Pebble/concentrate ratios in stippled areas: <1.0. Pebble/concentrate ratios in unstippled and gravel-patterned areas: $>1.0$. Gravel pattern is river pebble. Data for Tps. 31-32 S., secs. 14-23, T. 34 S., R. 24 E., and secs. 13, 22-24, T. 34 S., R. 23 E., from abundant company exploratory drilling; data for T. $33 \mathrm{~S}$. and the rest of T. $34 \mathrm{~S}$. from drill holes indicated by the following symbols : $\bullet$, pebble dominant; $\bigotimes$, concentrate dominant.

moved by flotation, but flotation was not used to separate quartz and phosphate in the $-14+16$ mesh fraction.

The $\mathrm{U}_{3} \mathrm{O}_{8} / \mathrm{P}_{2} \mathrm{O}_{5}$ ratios (table 4) are highest in the slime fraction, and they progressively decrease as grain size decreases. The relation of uranium to grain size indicates simply a greater uptake of uranium 
TABLE 4.-Analytical data, calcium phosphate zone

[Analyses by company chemists under contract to the U.S. Atomic Energy Comm. Mesh fraction: +5, +14 , coarse pebble; $-5+14,-14+16$, fine pebble; $-14+35,-16+150$, concentrate; -160 , slime]

\begin{tabular}{|c|c|c|c|c|c|c|c|}
\hline \multirow{2}{*}{ Location } & \multirow{2}{*}{$\begin{array}{l}\text { Number } \\
\text { of } \\
\text { samples }\end{array}$} & \multirow{2}{*}{$\begin{array}{l}\text { Mesh } \\
\text { fraction }\end{array}$} & \multicolumn{4}{|c|}{ Chemical analyses, 1 in percent } & \multirow{2}{*}{$\begin{array}{c}\text { Ratio } \\
\mathrm{U}_{3} \mathrm{O}_{3} / \mathrm{P}_{3} \mathrm{O}_{5}\end{array}$} \\
\hline & & & $\mathrm{P}_{9} \mathrm{O}_{6}$ & $\begin{array}{c}\mathrm{Fe}_{2} \mathrm{O}_{3}+\mathrm{Al}_{2} \mathrm{O}_{3} \\
(\mathrm{I} \text { and } \mathrm{A})\end{array}$ & $\begin{array}{c}\text { Insol- } \\
\text { uble }\end{array}$ & $\mathrm{U}_{8} \mathrm{O}_{8}$ & \\
\hline $\begin{array}{l}\text { T. } 31 \text { S., R. } 24 \text { E. } \\
\text { T. } 32 \text { S., R. } 24 \text { E... }\end{array}$ & 16 &  & $\begin{array}{l}30.76 \\
31.28 \\
31.51 \\
11.71 \\
30.31 \\
30.95 \\
31.22 \\
12.82 \\
31.89 \\
31.02 \\
34.76 \\
13.13\end{array}$ & $\begin{array}{rr}2.29 \\
2.33 \\
2.94 \\
2.91 \\
2.18 \\
\end{array}$ & $\begin{array}{r}8.65 \\
8.05 \\
6.98 \\
50.07 \\
8.59 \\
7.85 \\
7.65 \\
45.92 \\
9.87 \\
12.95 \\
3.20\end{array}$ & $\begin{array}{r}0.0203 \\
.0172 \\
.0136 \\
.0141 \\
.0207 \\
.0172 \\
.0134 \\
.0129 \\
.0142 \\
.0127 \\
.0093 \\
.0079\end{array}$ & $\begin{array}{l}1 / 1,520 \\
1 / 1,820 \\
1 / 2,140 \\
1 / 830 \\
1 / 1,460 \\
1 / 1,800 \\
1 / 2,330 \\
1 / 990 \\
1 / 2,250 \\
1 / 2,440 \\
1 / 3,740 \\
1 / 1,660\end{array}$ \\
\hline
\end{tabular}

1 Analyses are arithmetic averages of the samples.

from sea water by the coarser nodules than by the finer ones-a consequence of the coarser nodule's longer or more frequent exposures to sea water-but the high ratio in the slime fraction indicates concentration or enrichment of uranium in this fraction.

Whereas the analyses in table 4 are averages representing samples of the entire calcium phosphate zone, the analyses in table 5 are of single lithologic units of the calcium phosphate zone, and they illustrate some of the possible variations in phosphate and uranium content, in pebble/concentrate ratios, and in the variation of quartz and phosphate sand and slime.

The pebble/concentrate ratios of rocks from the Bone Valley Formation are less than 1.0 in samples from the low flatwoods in T. 32 S., R. 25 E., but are much larger than 1.0 in samples from the high flatwoods and ridge in T. 32 S., R. 24 E. Samples from the Hawthorn Formation all have low pebble/concentrate ratios-ranging from 0.1 to 1.8. The similarity of pebble/concentrate ratios of samples from the Hawthorn and Bone Valley Formations in the low flatwoods indicates that here much of the phosphate in the Bone Valley was derived from the Hawthorn Formation, and the marked difference of ratios in the two formations in the high flatwoods and ridge indicates that only a small part of the phosphate in the Bone Valley Formation was derived directly from the Hawthorn Formation.

The $\mathrm{P}_{2} \mathrm{O}_{5}$ content of the phosphate nodules is lowest in the pebble fraction of samples of residual calcareous clay of the Hawthorn Formation and highest in the concentrate samples from the Bone Valley Formation in a dominantly fine-grained deposit, in T. 32 S., R. 25 E. (fig. 6). The uranium content, on the other hand, is highest in the pebble fraction of the samples from the Bone Valley Formation in 
TABLE 5.-Analytical data, in percent, for samples of single lithologic units of the calcium phosphate zone

[Analyses of samples 1, 5, 9, 10, 12, and 13 by F. S. Grimaldi, U.S. Geol. Survey; the rest by company chemists under contract to the U.S. Atomic Energy Comm. P/C ratio: weight percent of pebble fraction $\frac{\text { weight percent of pebble fraction }}{\text { weight percent of concentrate fraction }}$

\begin{tabular}{|c|c|c|c|c|c|c|c|c|c|c|c|}
\hline \multirow{2}{*}{$\begin{array}{c}\text { Sample } \\
\text { No. }\end{array}$} & \multicolumn{3}{|c|}{ Pebble (+14 mesh) } & \multicolumn{3}{|c|}{ Concentrate $(-14+150$ mesh $)$} & \multirow{2}{*}{$\underset{\text { ratio }}{\mathbf{P} / \mathrm{C}}$} & \multicolumn{3}{|c|}{ Slime (-150 mesh) } & \multirow{2}{*}{ Remarks } \\
\hline & Weight & $\mathrm{P}_{2} \mathrm{O}_{5}$ & $\mathrm{U}$ & Weight & $\mathrm{P}_{2} \mathrm{O}_{5}$ & $\mathbf{U}$ & & Weight & $\mathrm{P}_{2} \mathrm{O}_{5}$ & $\mathbf{U}$ & \\
\hline $1 \ldots$ & 3.7 & 31.0 & 0.008 & 22.3 & 31.8 & 0.004 & 0.2 & 14.1 & 13.2 & 0.001 & Lower unit, Bone Valley Formation (lower flatwoods \\
\hline 40 & $\begin{array}{r}9.0 \\
9.4 \\
26.8\end{array}$ & $\begin{array}{l}32.9 \\
31.4 \\
29.8\end{array}$ & $\begin{array}{l}.012 \\
.015 \\
.017\end{array}$ & $\begin{array}{r}23.0 \\
10.4 \\
4.3\end{array}$ & $\begin{array}{l}35.7 \\
34.8 \\
31.2\end{array}$ & $\begin{array}{l}.009 \\
.009 \\
.014\end{array}$ & $\begin{array}{r}.4 \\
6.9 \\
6.2\end{array}$ & $\begin{array}{l}40.0 \\
48.9 \\
13.3\end{array}$ & $\begin{array}{r}14.7 \\
6.9 \\
7.5\end{array}$ & $\begin{array}{l}.007 \\
.004 \\
.005\end{array}$ & $\begin{array}{l}\text { Do. } \\
\text { Lower unit, Bone Valley Formation (higher flatwoods }\end{array}$ \\
\hline $\begin{array}{l}5 \\
6 \\
6 \\
8 \\
10 \\
11 \\
12 \\
13\end{array}$ & $\begin{array}{r}5.1 \\
18.3 \\
26.9 \\
48.4 \\
1.7 \\
9.7 \\
8.9 \\
13.9 \\
13.1 \\
5.4\end{array}$ & $\begin{array}{r}30.7 \\
31.2 \\
31.7 \\
29.7 \\
28.6 \\
29.3 \\
30.7 \\
9.3 \\
29.1\end{array}$ & $\begin{array}{l}.018 \\
.014 \\
.019 \\
.015 \\
.007 \\
.009 \\
.016 \\
.004 \\
.014\end{array}$ & $\begin{array}{r}0.8 \\
2.8 \\
2.8 \\
1.7 \\
28.4 \\
12.0 \\
4.9 \\
8.3 \\
\mathbf{N}\end{array}$ & \begin{tabular}{r|}
32.4 \\
30.8 \\
33.3 \\
19.4 \\
28.9 \\
30.3 \\
31.3 \\
29.4 \\
letermin
\end{tabular} & $\begin{array}{l}.012 \\
.009 \\
.014 \\
.005 \\
.003 \\
.004 \\
.011 \\
.008\end{array}$ & $\begin{array}{r}6.4 \\
6.6 \\
9.6 \\
28.4 \\
.1 \\
.8 \\
1.8 \\
1.6\end{array}$ & $\begin{array}{r}13.4 \\
2.3 \\
11.7 \\
0.7 \\
11.1 \\
20.7 \\
15.9 \\
63.2 \\
6.3\end{array}$ & $\begin{array}{r}17.6 \\
19.3 \\
17.1 \\
8.8 \\
4.0 \\
7.2 \\
12.2 \\
2.2 \\
2.2 \\
4.7\end{array}$ & $\begin{array}{l}.037 \\
.007 \\
.015 \\
.003 \\
.000 \\
.001 \\
.012 \\
.001 \\
.001\end{array}$ & $\begin{array}{l}\text { Do. } \\
\text { Do. } \\
\text { Do. } \\
\text { Do. } \\
\text { Calcareous clay, lower part of the Hawthorn Formation. } \\
\text { Do. } \\
\text { Do. } \\
\text { Limestone of the Hawthorn Formation. } \\
\text { Clastic rock, upper part of the Hawthorn Formation. }\end{array}$ \\
\hline
\end{tabular}


T. 32 S., R. 24 E., a coarse-grained deposit, and lowest in the concentrate fraction of samples from the Hawthorn Formation.

The slime ( -150 mesh) fraction is larger in samples from T. 32 S., R. 25 E., than in samples from T. 32 S., R. 24 E., but is largest in the sample of soft limestone (No. 12). Samples of the bedclay contain more slime than do samples from T. 32 S., R. 24 E., where the lower unit of the Bone Valley Formation is a sand. The $\mathrm{P}_{2} \mathrm{O}_{5}$ content of the slime fraction ranges from 2.2 to 19.3 percent and is generally somewhat lower in the samples from the Hawthorn than in samples from the Bone Valley. The uranium content generally varies directly with the phosphate content, but there are exceptions: in sample 1, the phosphate content is 13.2 percent, but the uranium content is only 0.001 percent; in sample 6 , which has the highest phosphate content19.3 percent-the uranium content is only 0.007 percent.

\section{$\mathbf{P}_{2} \mathrm{O}_{5}$ DISTRIBUTION}

The distribution of $\mathrm{P}_{2} \mathrm{O}_{5}$ in the size products of the calcium phosphate zone has been discussed in a previous report (Cathcart, 1963a). For the entire district, about two-thirds of the total $\mathrm{P}_{2} \mathrm{O}_{5}$ is in the pebble and concentrate fractions and the remainder is in the slime, although the quartz sand (tailings fraction) usually has a small percentage of $\mathrm{P}_{2} \mathrm{O}_{5}$. Individual samples differ greatly from the average (table 5). For example, if it is assumed that the quartz-sand fraction of sample 8 contains 2.0 percent $\mathrm{P}_{2} \mathrm{O}_{5}$, more than 91 percent of the $\mathrm{P}_{2} \mathrm{O}_{5}$ in the sample is in the pebble fraction and less than 1 percent is in the slime fraction. Sample 2 (table 5) is very close to the district average: 63 percent of the toal $\mathrm{P}_{2} \mathrm{O}_{5}$ is in the pebble and concentrate fractions, 33 percent is in the slime, and the rest is in the quartz sand.

Details of the areal distribution of $\mathrm{P}_{2} \mathrm{O}_{5}$ are considered confidential by the companies, and only the more general aspects can be considered here. The $\mathrm{P}_{2} \mathrm{O}_{5}$ content of the phosphate nodules is lower near stream courses than in the interstream divides (Cathcart, 1963a), probably because of leaching of $\mathrm{P}_{2} \mathrm{O}_{5}$ from the nodules by acid ground water. The $\mathrm{P}_{2} \mathrm{O}_{5}$ content of the phosphate nodules tends to be somewhat lower in the southern and western parts of the quadrangle than in the areas close to the Peace River, and there seems to be a tendency for the $\mathrm{P}_{2} \mathrm{O}_{5}$ content of the nodules to decrease southward.

URANIUM DISTRIBUTION

The distribution of the uranium in the pebble and concentrate fractions (pls. 5, 6) is controlled, at least in part, by the present drainage. Areas at or close to the present streams are underlain by phosphate nodules containing less than 0.010 percent uranium and sometimes less than 0.005 percent uranium; under the interstream divides 
the uranium content of the phosphate nodules is much higher. The isopleths are similar to topographic contours in that they are deeply indented headward along the streams and are closed on the interstream divides.

The pebble fraction contains more uranium than does the concentrate fraction. For example, large areas in the north half of the quadrangle are underlain by pebble-size phosphate nodules containing 0.015 percent uranium (pl. 5) ; the highest uranium content of the pebble fraction is slightly more than 0.045 percent in the $\mathrm{SW} 1 / 4$ sec. 34, T. 31 S., R. 24 E. Areas underlain by concentrate-size phosphate nodules containing 0.015 percent uranium are small (pl. 6) ; concentrate-size nodules richest in uranium $(>0.020$ percent) are found in the SE $1 / 4$ sec. 8 , T. 32 S., R. 25 E. The uranium content of the pebble fraction is lower in the south half of the quadrangle than in the north half (pl. 5). For example, only one small area in the south half of the quadrangle is underlain by pebble which contains 0.020 percent uranium and throughout most of the south half of the quadrangle the uranium content of the pebble is between 0.010 and 0.015 percent.

The reasons for the difference in uranium content is not known. In the south half of the quadrangle, however, the phosphate is lower in $\mathrm{P}_{2} \mathrm{O}_{5}$ content and the coarse nodules are more uniform in size and are simple in texture, whereas in the north half the phosphate is higher in $\mathrm{P}_{2} \mathrm{O}_{5}$ content, the nodules show a much greater variation in size, and the coarse phosphate nodules are texturally complex. Texturally simple nodules are dominantly apatite. Texturally complex nodules contain smaller phosphate pellets, fragments of other nodules, clastic quartz, and fragments of phosphatized limestone. The more complex nodules have probably been reworked several times, and the simpler perhaps only once. Altschuler, Clarke, and Young (1958, p. 67) pointed out that "re-exposure to sea water sustained by the reworked Bone Valley material allowed additional uptake of uranium." The phosphate nodules at the south end of the quadrangle were farther from the Bone Valley shoreline and were probably reworked only once; those further north, closer to the shoreline, were probably reworked several times and therefore contain more uranium.

The concentrate fraction does not decrease in uranium content toward the south (pl. 6). In the south half of the quadrangle there are no significant differences in the uranium contents of the pebble and concentrate fractions. In general, much of the coarser pebble is in the lower part of the lower unit of the Bone Valley Formation where as the concentrate tends to be in the upper part of the lower unit, deposited farther from the shoreline, in quieter water. The 
concentrate was probably reworked only once, and thus is lower and more uniform in uranium content.

The uranium content of the phosphate particles and of the waste products varies considerably in a vertical section (fig. 7). The pebble fraction (+14 mesh) contains little or no uranium in the clayey sand of the upper unit of the Bone Valley Formation. In the base of the upper unit, where phosphate nodules are more abundant, the uranium content of the pebble fraction increases very sharply and is at its maximum in the bottom sample of the upper unit. The uranium content of the pebble fraction of the lower unit is highest in the top of the unit and then decreases slowly but steadily to the base of the section-the top of the Hawthorn Formation.

Distribution of the uranium content of the coarse-feed fraction $(-14+35$ mesh) closely resembles that of the pebble fraction, except that the uranium content of the first is only about one-third as much as that of the second.

The slime fraction ( -150 mesh) in the top two beds of the upper unit of the Bone Valley Formation contains some uranium; the uranium content increases very sharply below these beds and reaches a maximum just below the middle of the upper unit, in the sample where visible phosphate first becomes abundant. The uranium content of the slime fraction of the bottom two samples of the upper unit is very low. This sharp decrease probably represents the lower limit of leaching in this section. The uranium content of the slime fraction increases somewhat in the lower unit of the Bone Valley Formation and then decreases again in the sample from the Hawthorn Formation.

The quartz-sand fraction $(-35+150$ mesh) contains almost no uranium.

\section{$\mathrm{P}_{2} \mathrm{O}_{5}, \mathrm{U}_{3} \mathrm{O}_{8}$, FLUUORINE RELATIONS}

Uranium, fluorine, and $\mathrm{P}_{2} \mathrm{O}_{5}$ are closely allied in distribution in unscreened samples (pl. 7A). All three constituents are much more abundant in the top bed of the upper unit of the Bone Valley Formation than in the sand of Pleistocene age. The clayey sand of the upper unit of the Bone Valley Formation contains much less fluorine than do samples from the rest of the section, and the ratio of percent fluorine to percent $\mathrm{P}_{2} \mathrm{O}_{5}$ is about 0.06 , but in the rest of the section it is greater than 0.1 . The difference in the ratio is a reflection of the difference in mineralogy: in the upper part of the section the phosphate minerals are wavellite and crandallite, and in the lower part the phosphate mineral is fluorapatite.

The distributions of uranium, fluorine, and $\mathrm{P}_{2} \mathrm{O}_{5}$ in the pebble and concentrate fractions are very similar (pl. $7 B$ ). The similarity of 
38 ECONOMIC GEOLOGY, FORT MEADE QUADRANGLE, FLORIDA

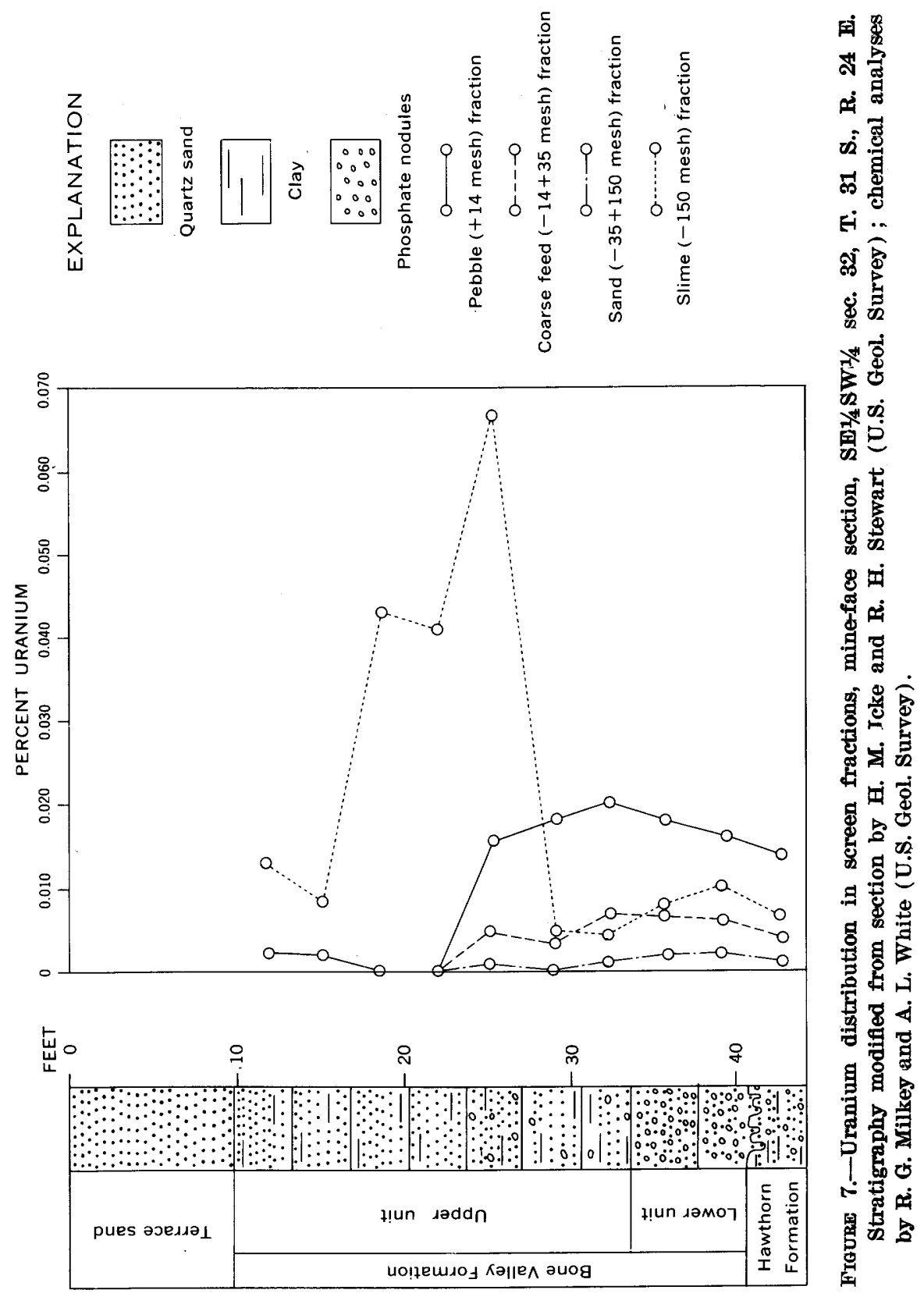


lines for uranium and $\mathrm{P}_{2} \mathrm{O}_{5}$ content indicates the close relationship between these components. The ratio of fluorine to $\mathrm{P}_{2} \mathrm{O}_{5}$ in samples from the upper unit of the Bone Valley Formation and in the sand of Pleistocene age is very low; this indicates that the phosphate mineral in these beds is crandallite or wavellite. In the beds of the lower unit of the Bone Valley Formation the ratio of fluorine to $\mathrm{P}_{2} \mathrm{O}_{5}$ indicates that the phosphate mineral is a fluorapatite.

The slime fraction is present in more than trace amounts only in clayey sand of the upper unit of the Bone Valley Formation and reaches a maximum in a clay bed in about the middle of the upper unit $(\mathrm{pl} .7 C)$. The uranium, fluorine, and $\mathrm{P}_{2} \mathrm{O}_{5}$ contents of the slime fraction are comparable in distribution throughout the section and are uniformly low, except in the sample directly above the clay bed, where the high contents probably resulted from concentration by downwardmoving acid ground water in the bed immediately above the more impermeable clay bed.

The shape of the curves of uranium and $\mathrm{P}_{2} \mathrm{O}_{5}(\mathrm{pl} .7 \mathrm{~B}, C)$ show that these constituents are directly related. To determine the relation more precisely, scatter diagrams were drawn (fig. 8). The phosphorus content is expressed as percent BPL $\left(\mathrm{P}_{2} \mathrm{O}_{5}\right.$ percent $\left.\times 2.185\right)$ and the uranium content as percent $\mathrm{U}_{3} \mathrm{O}_{8}$. The coarser fractions contain more $\mathrm{U}_{3} \mathrm{O}_{8}$ and less BPL than do the finer fractions, as shown in the plots on the diagrams of the averages of each of the fractions. The finer fractions plot at successively higher BPL and lower $\mathrm{U}_{3} \mathrm{O}_{8}$ contents.

The diagrams show plots of the screened fractions for samples of the Bone Valley (fig. 8, middle) and for the entire calcium phosphate zone (fig. 8, lower) in deposits characterized by coarse phosphate, and for the entire calcium phosphate zone in a deposit characterized by fine phosphate (fig. 8, upper). The plots of individual fractions of coarse or fine phosphate on all the diagrams show only very slight positive correlation, and the plots of all samples on each diagram show a slight negative correlation. The plots of the average values for each size group show a negative correlation.

The reason for the virtual lack of correlation in the scatter diagrams and the positive correlation indicated by plate 7 is probably difference in sampling. Plots on the scatter diagrams are for a single sample of all beds of the, calcium phosphate zone; the plots on the vertical sections (pl. 7) are for individual beds.

Percent BPL and percent $\mathrm{U}_{3} \mathrm{O}_{8}$ in the slime fraction of the calcium phosphate zone show a fairly distinct positive correlation (fig. 9A) for both coarse and fine deposits. The plots of the samples from the coarse deposit are generally separated from those from the fine de- 

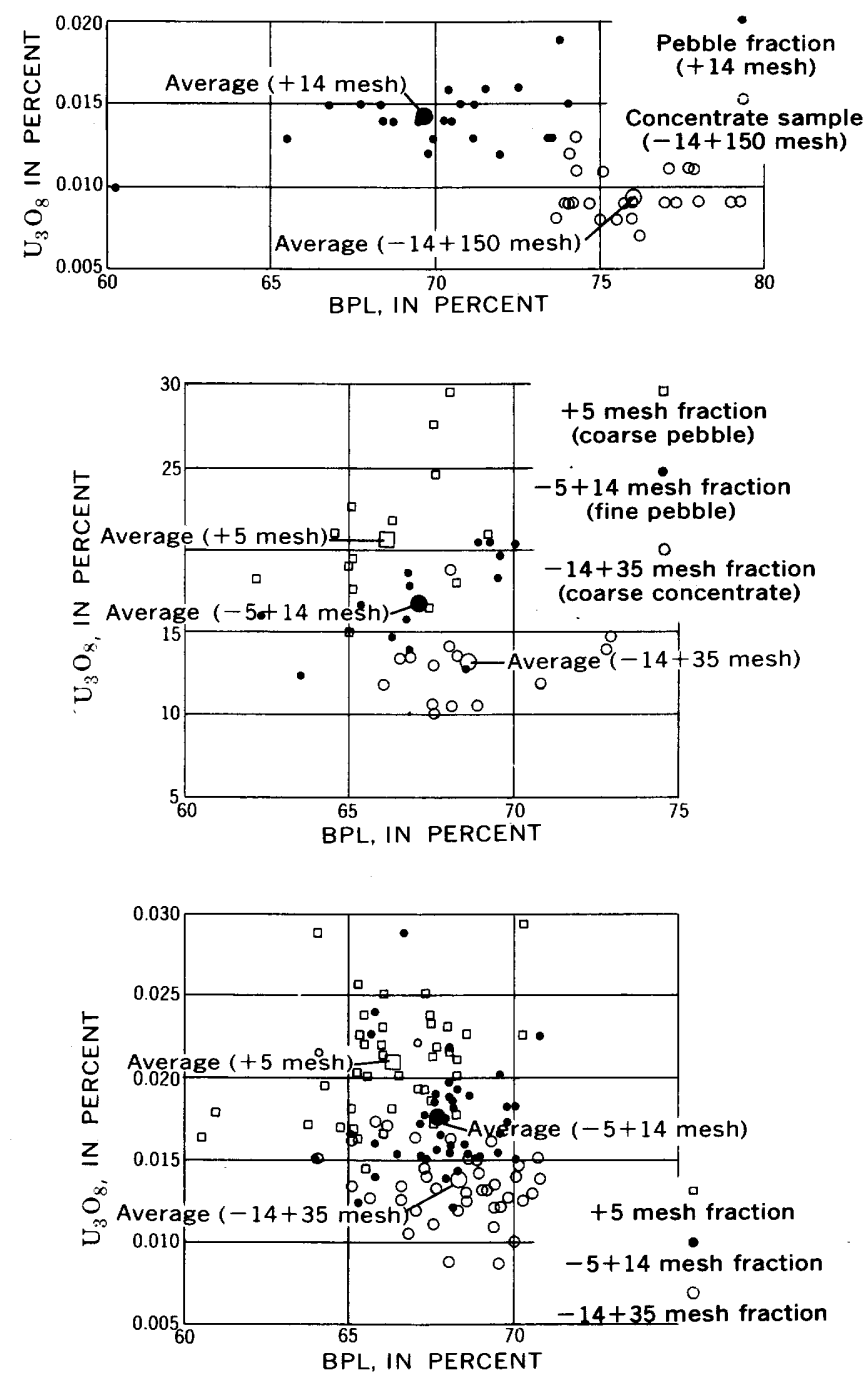

Figure 8.- $\mathrm{U}_{3} \mathrm{O}_{8}, \mathrm{BPL}\left(\mathrm{P}_{2} \mathrm{O}_{5} \times 2.185\right)$ relations in screened fractions of samples from the calcium phosphate zone. Upper: Concentrate deposit. Middle: Coarse-pebble deposit, lower unit of the Bone Valley Formation. Lower: Coarse-pebble deposit, Bone Valley and Hawthorn Formations.

posits, because the samples from the coarse deposit contain more uranium than do the samples from the fine deposit.

\section{BPL, ACID-INSOLUBLE CONTENT RELATIONS}

The relation between BPL and acid insoluble is inverse, and the correlation is fairly distinct (fig. 9). The pebble and concentrate frac- 


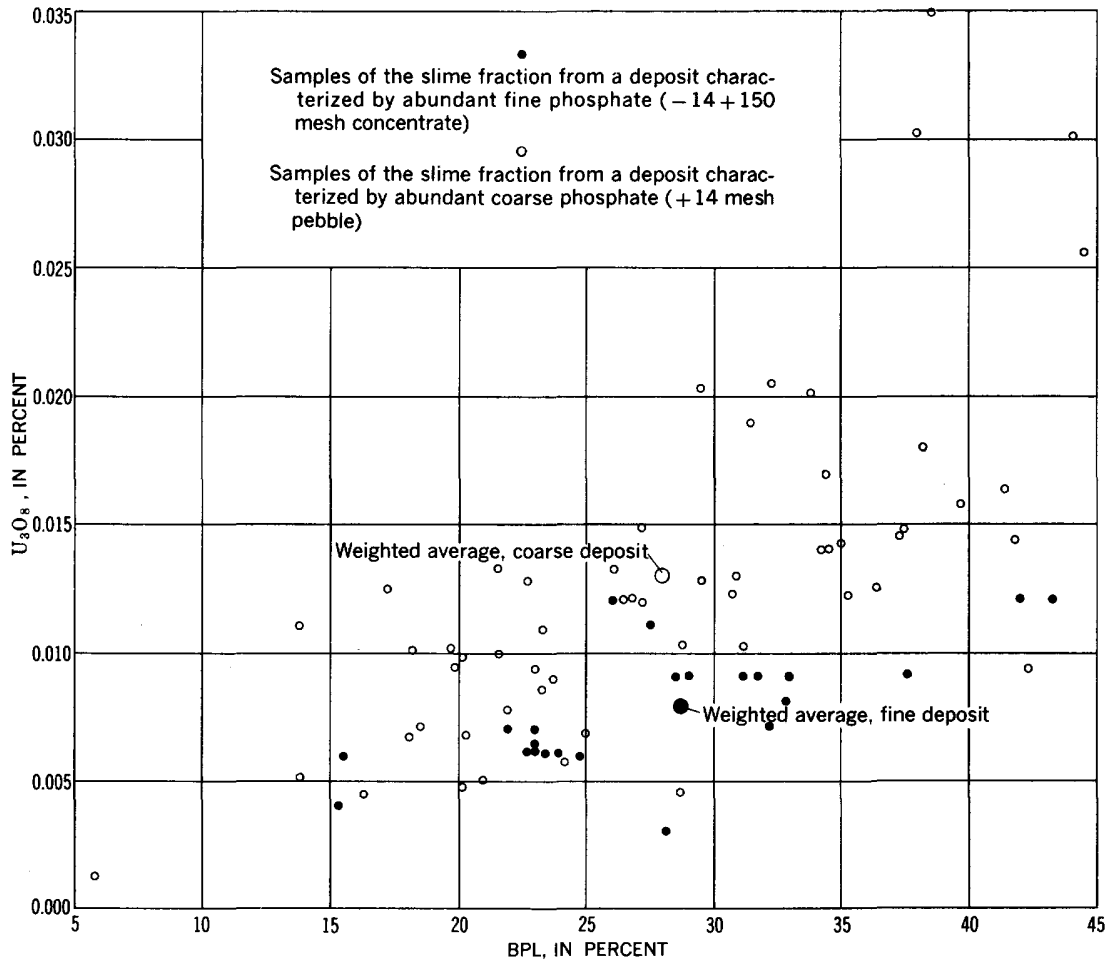

A. $\mathrm{U}_{3} \mathrm{O}_{8}$ AND BPL, SLIME FRACTION



B. ACID INSOLUBLE AND BPL, PHOSPHATE NODULES

FIGURE 9.- $\mathrm{U}_{8} \mathrm{O}_{8}, \mathrm{BPL}\left(\mathrm{P}_{2} \mathrm{O}_{5} \times 2.185\right)$ and acid insoluble, $\mathrm{BPL}$ relations, calcium phosphate zone. Analyses by company chemists under contract to the U.S. Atomic Energy Commission. 
tions from which the analyses were made are from samples of the economic part of the calcium phosphate zone from T. 32 S., R. 25 E. The concentrate samples are high in BPL and low in acid insoluble and all plot in about the same position, whereas the plot of the pebble samples is scattered over the diagram. The diagram (fig. 9) shows that acidinsoluble content, principally silica, is the main diluent in the phosphate nodules.

\section{ALUMINUM PHOSPHATE ZONE}

The aluminum phosphate zone is a zone of alteration formed by downward-percolating acid ground waters. Characteristically, the zone consists of a clayey sand, which is white or very light colored, contains no visible phosphate particles except at the base, and contains aluminum phosphate or calcium-aluminum phosphate minerals rather than calcium phosphate minerals. The uranium content of the zone is usually high, and typically both the uranium and the phosphate are concentrated in the -150 mesh (slime) fraction.

Prospecting for the aluminum phosphate zone was done in two areas in the Fort Meade quadrangle: the Watson tract, close to the Peace River, and the Consolidated tract, in the western part of the quadrangle close to the ridge area.

At the Watson tract the zone is a white to light-gray, slightly clayey to clayey sand that locally is stained yellow or brown by iron oxide. At the base of the zone the rock is more clayey and is commonly a sandy clay. Sandrock (lumps or fragments of sand cemented by aluminum phosphate) is common throughout the section, and nodules of soft, white phosphate are ordinarily present at the base of the aluminum phosphate zone, just above the matrix. A vesicular material is present at the base of the zone at a few drill holes. The aluminum phosphate zone at the Watson tract represents a thoroughly leached section. The leaching has affected the entire upper unit of the Bone Valley Formation and has extended down into the top of the lower unit (at those localities having material of vesicular texture). A typical section of the leached material at the Watson tract is shown in $\log \mathrm{L}$ (p. 76).

At the Consolidated tract the aluminum phosphate zone consists of gray, gray-green, or white clayey sand or sandy clay. The white clayey sand is characteristically at the top of the unit. Soft, white phosphate nodules are present at a few of the drill-hole locations, and at many locations trace amounts of fresh black or brown phosphate nodules occur at the base of the section, just above the matrix. Small amounts of sandrock were cut by some drill holes; but vesicular material was not present. Evidently the leaching at the Consolidated tract was not as intense as the leaching at the Watson tract. Leaching 
did not extend down into the lower unit, and in places it affected only the top of the upper unit of the Bone Valley Formation (at those localities where fresh black or brown phosphate occurs in the upper unit, above the matrix).

The log of drill hole I (p. 63) is typical of the section at the Consolidated tract. At this drill hole the bottom part of the material analyzed as leached zone by the company (the basal part of the upper unit of the Bone Valley Formation) contains fresh calcium phosphate nodules and is, by definition, a part of the calcium phosphate zone but not part of the matrix.

\section{DISTRIBUTION AND THICKNESS}

The aluminum phosphate zone underlies the entire quadrangle except along the present-day streams, where it has been removed by erosion (pl. 8). The zone ranges in thickness from 0 to about 25 feet and probably averages 5-10 feet. Only in small areas is the aluminum phosphate zone more than 15 feet thick.

\section{ANALYTICAL DATA}

Analytical data for the aluminum phosphate zone are not abundant. All data are from company drilling done under contract to the U.S. Atomic Energy Commision. The analytical data summarized in table 6 comprise arithmetic averages of analyses of samples from different holes; each sample represents the entire aluminum phosphate zone in the drill hole from which it came. The samples from each of the three tracts were averaged. The data from the South Pierce tract and from the Consolidated tract are very similar, except that the analyses for all the elements are slightly higher in the Consolidated tract than in the South Pierce tract. The difference is probably due to acid insoluble (not reported), which would be lower in the Consolidated tract.

The assay data from samples taken in the Watson tract differ considerably from the data from samples taken in the Consolidated and South Pierce tracts, and the differences indicate that leaching was more thorough at the Watson tract.

\section{$P_{2} 0_{5}$ CONTENT}

$\mathrm{P}_{2} \mathrm{O}_{5}$ is concentrated in the slime fraction at all three tracts (table 6). The pebble fraction, although high in $\mathrm{P}_{2} \mathrm{O}_{5}$, contains only a small percent of the total $\mathrm{P}_{2} \mathrm{O}_{5}$ in the aluminum phosphate zone because of the small amount of this fraction; and the sand fraction, although it is the most abundant, is so low in $\mathrm{P}_{2} \mathrm{O}_{5}$ that it contains only a small percent of the total $\mathrm{P}_{2} \mathrm{O}_{5}$. An average of about two-thirds of the total $\mathrm{P}_{2} \mathrm{O}_{5}$ is concentrated in about one-third of the total weight of the zone. The Watson tract, where the aluminum phosphate zone has been most thoroughly leached, contains the highest concentration of $\mathrm{P}_{2} \mathrm{O}_{5}$ in the 
TABLE 6.-Analytical data, and distribution of $\mathrm{P}_{2} \mathrm{O}_{5}, \mathrm{U}_{3} \mathrm{O}_{8}, \mathrm{CaO}, \mathrm{Al}_{2} \mathrm{O}_{3}$, and $\mathrm{FO}_{2} \mathrm{O}_{3}$ in the screen fractions of the aluminum phosphate zone, Fort Meade quadrangle

[Analyses by company chemists under contract to the U.S. Atomic Energy Comm.]

\begin{tabular}{|c|c|c|c|c|c|c|c|c|c|c|c|c|c|c|c|}
\hline \multirow{2}{*}{ Location } & \multirow{2}{*}{$\begin{array}{c}\text { Number } \\
\text { of } \\
\text { samples }\end{array}$} & \multirow{2}{*}{$\underset{\text { Mraction }}{\text { Mesh }}$} & \multirow{2}{*}{$\begin{array}{l}\text { Weight } \\
\text { percent }\end{array}$} & \multicolumn{5}{|c|}{ Analyses, in percent } & \multicolumn{2}{|c|}{ Ratios } & \multicolumn{5}{|c|}{ Distribution, in percent, in screen fractions } \\
\hline & & & & $\mathrm{P}_{2} \mathrm{O}_{5}$ & $\mathrm{U}_{3} \mathrm{O}_{8}$ & $\mathrm{CaO}$ & $\mathrm{Al}_{2} \mathrm{O}_{3}$ & $\mathrm{Fe}_{2} \mathrm{O}_{3}$ & $\mathrm{U}_{3} \mathrm{O}_{8} / \mathrm{P}_{2} \mathrm{O}_{5}$ & $\mathrm{CaO} / \mathrm{P}_{2} \mathrm{O}_{5}$ & $\mathrm{P}_{2} \mathrm{O}_{5}$ & $\mathrm{U}_{3} \mathrm{O}_{8}$ & $\mathrm{CaO}$ & $\mathrm{Al}_{2} \mathrm{O}_{3}$ & $\mathrm{Fe}_{2} \mathrm{O}_{3}$ \\
\hline $\begin{array}{l}\text { South Pierce tract (T. } 31 \text { S., } \\
\text { R. } 24 \text { E.) }\end{array}$ & 15 & $\left\{\begin{array}{r}+14 \\
-14+150 \\
-150\end{array}\right.$ & $\begin{array}{r}2.0 \\
76.3 \\
21.7\end{array}$ & $\begin{array}{r}18.30 \\
.98 \\
8.12\end{array}$ & $\begin{array}{r}0.0152 \\
.0008 \\
.0196\end{array}$ & $\begin{array}{r}17.74 \\
1.01 \\
3.81\end{array}$ & $\begin{array}{r}5.78 \\
11.95 \\
11.32\end{array}$ & $\begin{array}{r}0.85 \\
.57 \\
.90\end{array}$ & $\begin{array}{l}1 / 1,200 \\
1 / 1,230 \\
1 / 400\end{array}$ & $\begin{array}{r}0.969 \\
1.030 \\
.469\end{array}$ & $\begin{array}{l}12.7 \\
26.0 \\
61.3\end{array}$ & $\begin{array}{r}5.9 \\
11.8 \\
82.3\end{array}$ & $\begin{array}{l}18.2 \\
39.5 \\
42.3\end{array}$ & $\begin{array}{r}3.5 \\
22.0 \\
74.5\end{array}$ & $\begin{array}{r}2.9 \\
73.1 \\
24.0\end{array}$ \\
\hline $\begin{array}{l}\text { Consolidated tract (T. } 32 \text { S., } \\
\text { R. } 24 \text { E.) }\end{array}$ & 49. & $\left\{\begin{array}{r}\text { Head } \\
+14 \\
-14+150 \\
-150 \\
\text { Head }\end{array}\right.$ & $\begin{array}{r}100.0 \\
1.4 \\
72.3 \\
26.3 \\
100.0\end{array}$ & $\begin{array}{r}2.87 \\
22.63 \\
1.04 \\
9.31 \\
3.34\end{array}$ & $\begin{array}{l}.0048 \\
.0185 \\
.0007 \\
.0203 \\
.0050\end{array}$ & $\begin{array}{r}1.98 \\
27.29 \\
1.29 \\
5.94 \\
2.86\end{array}$ & $\begin{array}{r}3.28 \\
3.70 \\
.47 \\
12.38 \\
3.44\end{array}$ & $\begin{array}{r}.66 \\
.89 \\
.51 \\
1.03 \\
.69\end{array}$ & $\begin{array}{l}1 / 600 \\
1 / 1,220 \\
1 / 1,490 \\
1 / 460 \\
1 / 670\end{array}$ & $\begin{array}{r}.690 \\
1.206 \\
1.240 \\
.638 \\
.856\end{array}$ & $\begin{array}{r}9.0 \\
21.4 \\
69.6\end{array}$ & $\begin{array}{r}4.2 \\
8.3 \\
87.5\end{array}$ & $\begin{array}{l}13.3 \\
32.4 \\
84.3\end{array}$ & $\begin{array}{r}1.4 \\
9.3 \\
89.3\end{array}$ & $\begin{array}{r}1.9 \\
56.6 \\
41.5\end{array}$ \\
\hline$\underset{\text { E.) }}{\text { Watson tract (T. } 32 \text { S., R. } 25}$ & 23 & $\begin{array}{r}+16 \\
-16+150 \\
-150 \\
\text { Head }\end{array}$ & $\begin{array}{r}100.0 \\
4.9 \\
55.4 \\
39.7 \\
100.0\end{array}$ & $\begin{array}{r}12.04 \\
12.42 \\
12.96 \\
6.92\end{array}$ & $\begin{array}{l}.0000 \\
.0090 \\
.0017 \\
.0206 \\
.0096\end{array}$ & $\begin{array}{l}2.80 \\
2.37 \\
.29 \\
3.51 \\
1.67\end{array}$ & $\begin{array}{r}3.44 \\
10.86 \\
2.44 \\
19.52 \\
9.63\end{array}$ & $\begin{array}{l}.09 \\
1.69 \\
.74 \\
3.48 \\
1.87\end{array}$ & $\begin{array}{l}1 / 11,380 \\
1 / 1,240 \\
1 / 1,240 \\
1 / 630 \\
1 / 720\end{array}$ & $\begin{array}{l}.850 \\
.191 \\
.137 \\
.271 \\
.241\end{array}$ & $\begin{array}{r}8.8 \\
16.9 \\
74.3\end{array}$ & $\begin{array}{r}.5 \\
10.3 \\
89.2\end{array}$ & $\begin{array}{r}7.0 \\
9.6 \\
83.4\end{array}$ & $\begin{array}{r}5.5 \\
14.0 \\
80.5\end{array}$ & $\begin{array}{r}4.4 \\
21.9 \\
73.7\end{array}$ \\
\hline
\end{tabular}

1 This tract is in both the Fort Meade and Bartow quadrangles, but only the drill holes in the Fort Meade quadrangle are considered here. 
slime fraction. Thorough leaching has dissolved the phosphate particles, the $\mathrm{P}_{2} \mathrm{O}_{5}$ has combined with the clay minerals, and the resulting fine-grained aluminum phosphate minerals are concentrated in the slime fraction.

In the low flatwoods adjoining the Peace River, in R. 25 E. (fig. 10), the aluminum phosphate zone is high in $\mathrm{P}_{2} \mathrm{O}_{5}$; in large areas the zone contains more than 5 percent $\mathrm{P}_{2} \mathrm{O}_{5}$, and the average $\mathrm{P}_{2} \mathrm{O}_{5}$ content is 6.92 percent (table 6 ). In the high flatwoods or ridge, in R. 24 E., the $\mathrm{P}_{2} \mathrm{O}_{5}$ content of the aluminum phosphate zone is low; only in very small areas underlain by the zone is the $\mathrm{P}_{2} \mathrm{O}_{5}$ content as much as 5 percent, and the average is only about 3 percent (table 6 ).

\section{URANIUM CONTENT}

Distribution of uranium in the aluminum phosphate zone (pl. 9) closely follows the distribution of $\mathrm{P}_{2} \mathrm{O}_{5}$ in the zone (fig. 10). The uranium content of the zone is low along present-day streams, is high under the interstream divides, and is highest in the flatwoods area adjacent to the valley of the Peace River.

The high uranium content at the west edge of the map, at the boundary between Tps. 32-33 S., was determined from gamma-ray logs. No chemical analyses are available for the zone in this area, but the $\mathrm{P}_{2} \mathrm{O}_{5}$ content may be greater than 5 percent.

\section{$\mathbf{P}_{2} \mathrm{O}_{5}, \mathrm{U}_{3} \mathrm{O}_{8}$ RELATIONS}

In the aluminum phosphate zone the uranium content increases as the phosphate content increases; the diagrams (fig. 11) show the concentration of both uranium and $\mathrm{P}_{2} \mathrm{O}_{5}$ in the -150 mesh fraction. Uranium is present in the phosphate minerals, and the phosphate minerals are concentrated in the slime fraction.

Head samples from the Watson tract are distinctly higher in both $\mathrm{P}_{2} \mathrm{O}_{5}$ and $\mathrm{U}_{3} \mathrm{O}_{8}$ than are the samples from the Consolidated tract (fig. 11). The relation in the slime samples (fig. 11) is not so clear. Most of the samples from the Watson tract are richer in $\mathrm{P}_{2} \mathrm{O}_{5}$ than are the samples from the Consolidated tract, but many of the samples from the Consolidated tract are richer in $\mathrm{U}_{3} \mathrm{O}_{8}$ than are the samples from the Watson tract. The samples rich in $\mathrm{U}_{3} \mathrm{O}_{8}$ are those in which the uranium is concentrated in a very small volume of -150 mesh material, probably calcium-aluminum phosphate (fig. 11, lower).

The $\mathrm{U}_{3} \mathrm{O}_{8} / \mathrm{P}_{2} \mathrm{O}_{5}$ ratio is much higher in the slime fraction than in the pebble or sand fraction of the aluminum phosphate zone (table 6). 'The ratios are higher in samples from R. 24 E. than in samples from R. 25 E. The higher ratios in the slime fraction are a reflection of the enrichment of $\mathrm{U}_{3} \mathrm{O}_{8}$ relative to $\mathrm{P}_{2} \mathrm{O}_{5}$ in this fraction. 


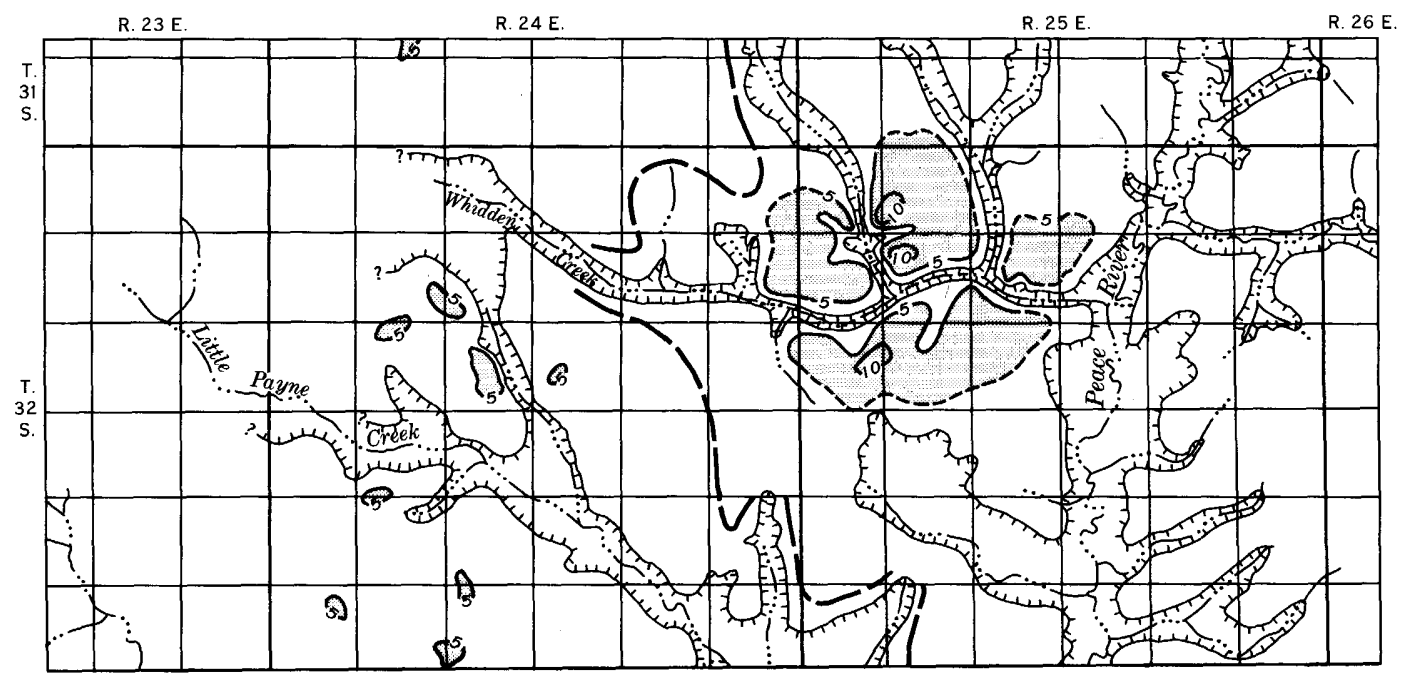

EXPLANATION

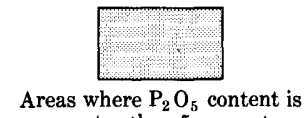
Areas where $\mathrm{P}_{2} \mathrm{O}_{5}$ content is
greater than 5 percent

$$
50
$$

Showing $\mathrm{P}_{2} \mathrm{O}_{5}$ grade of the aluminum phosphate zone in percent. Dashed where inferred. Contour interval 5 percent $\mathrm{P}_{2} \mathrm{O}_{5}$

$$
\pi \rightarrow 3
$$

Areas where the aluminum phosphate zone is less than 3 feet thick or is absent

ndary between the ridge and high flat woods on the west and the valley and low flatwoods on the east

$$
\begin{array}{lllllll}
0 & 1 & 2 & 3 & 4 & 5 & 6 \\
1 & 1 & 1 & 1 & 1 & 1 & \text { MILES }
\end{array}
$$

FIGURE 10.-Distribution of $\mathrm{P}_{2} \mathrm{O}_{5}$ in the aluminum phosphate zone, northern part of the Fort Meade quadrangle, Florida. 

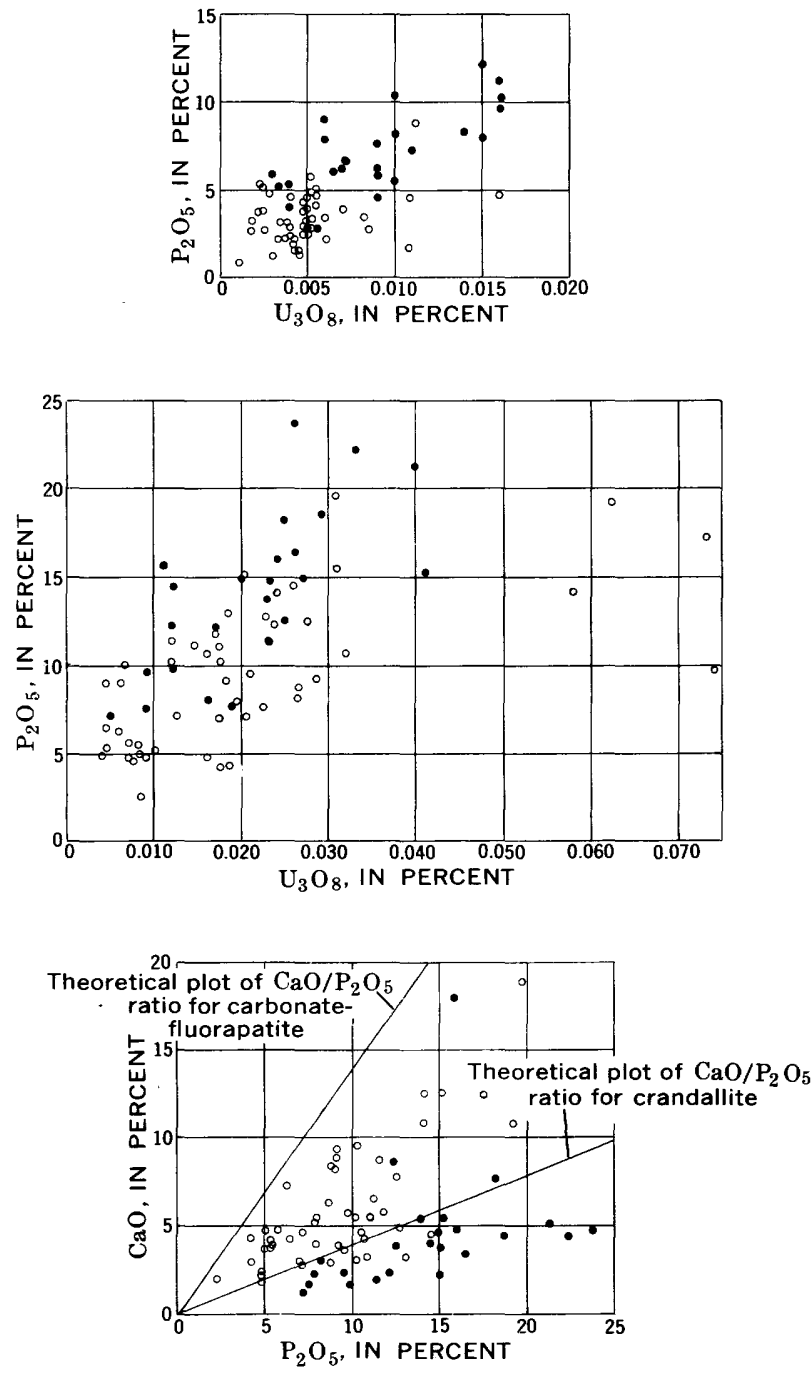

Figure 11. $-\mathrm{P}_{2} \mathrm{O}_{5}, \mathrm{U}_{3} \mathrm{O}_{3}$ and $\mathrm{P}_{2} \mathrm{O}_{5}, \mathrm{CaO}$ relations in the aluminum phosphate zone. Upper: Untreated (head) samples. Middle and lower: $\mathbf{- 1 5 0}$ mesh (slime) fraction.

The $\mathrm{U}_{3} \mathrm{O}_{8} / \mathrm{P}_{2} \mathrm{O}_{5}$ ratios of the phosphate in the aluminum phosphate zone are considerably higher than the ratios in the calcium phosphate zone (tables 4,6). This is an indication of the secondary enrichment of uranium in the aluminum phosphate zone.

\section{$\mathrm{CaO}, \mathrm{P}_{2} \mathrm{O}_{5}$ RELATIONS}

The ratio of percent $\mathrm{CaO}$ to percent $\mathrm{P}_{2} \mathrm{O}_{5}$ is roughly indicative of the degree of intensity of the leaching. The $\mathrm{CaO} / \mathrm{P}_{2} \mathrm{O}_{5}$ ratio for 
carbonate-fluorapatite, the mineral of the unaltered calcium phosphate zone, is 1.42 ; the ratio for crandallite, a calcium-aluminum phosphate mineral characteristic of partially leached material, is 0.39 ; and wavellite, the aluminum phosphate mineral characteristic of the most intensely leached sections, contains no $\mathrm{CaO}$. The $\mathrm{CaO} / \mathrm{P}_{2} \mathrm{O}_{5}$ ratios in R. 24 E. are much higher than the ratios in R. 25 E. (table 6); this indicates that the samples from R. 25 E. were much more thoroughly leached than the samples from R. 24 E.

The correlation between $\mathrm{P}_{2} \mathrm{O}_{5}$ and $\mathrm{CaO}$ in the slime fraction of the aluminum phosphate zone is direct and moderately distinct (fig. 11). Almost 88 percent of the plots of the samples from the Consolidated tract fall between the lines representing the $\mathrm{CaO} / \mathrm{P}_{2} \mathrm{O}_{5}$ ratios of crandallite and apatite, and about 87 percent of the plots of the samples from the Watson tract fall below the line representing the $\mathrm{CaO} / \mathrm{P}_{2} \mathrm{O}_{5}$ ratio for crandallite. Much more of the calcium has been leached from the Watson tract than from the Consolidated tract.

\section{TONNAGE CALCULATIONS}

\section{CALCIUM PHOSPHATE ZONE}

The total area of the Fort Meade quadrangle is about 166,000 acres. Prospecting for the calcium phosphate zone has covered about 71,000 acres-about 43 percent of the total area, mostly in the north half of the quadrangle. Total reserves in this area are 208.8 million long tons of the pebble fraction and 108.9 million long tons of the concentrate fraction.

The calcium phosphate zone is probably present throughout the southern part of the quadrangle. Scattered data indicate that the concentrate fraction is more abundant than the pebble fraction in the area close to the Peace River, but that in the rest of the southern part of the quadrangle the pebble fraction is more abundant than the concentrate. The ratio of tonnage of pebble to tonnage of concentrate in the south half of the quadrangle is about the same as it is in the north half, that is, about $2: 1$. Additional large amounts of phosphate are present in the southern part of the quadrangle, but in some areas the material is probably too low in grade to be economic, and in others the tonnage is probably insufficient to be economic.

The average uranium content is slightly more than 0.014 percent in the pebble fraction and is 0.010 percent in the concentrate fraction. These figures are based on from one to five analyses from each of 770 drill holes sampled for the pebble fraction and from one to five analyses from each of 580 drill holes sampled for the concentrate frac- 
tion. Reserves calculated from these data are 29,400 long tons of uranium in the pebble fraction and 12,200 long tons in the concentrate fraction; this yields a total of 41,600 long tons of uranium in the phosphate of the Fort Meade quadrangle.

\section{ALUMINUM PHOSPHATE zONE}

Chemical analyses used for computing reserves of the aluminum phosphate zone are of samples from 87 drill holes in an area of 3,480 acres; these are supplemented by gamma-ray logs of about 300 drill holes over an area of 10,880 acres. Indicated reserves in these areas are about 241 million long tons of aluminum phosphate zone that contains about 18,500 long tons of $\mathrm{U}_{3} \mathrm{O}_{8}$ (table 7).

The prospected area is only about 8.5 percent of the total area of the quadrangle. The isopach map of the aluminum phosphate zone (pl. 8 ) shows that an additional 60,000 acres is underlain by an aluminum phosphate zone that is about 5 feet thick. The isopleth map of uranium content (pl. 9) indicates that the aluminum phosphate zone in this area contains between 0.005 and 0.010 percent $\mathrm{U}_{3} \mathrm{O}_{8}$. If these estimates represent the average thickness and uranium content then there is an inferred reserve of about 500 million long tons of aluminum phosphate zone containing about 35,000 long tons of $\mathrm{U}_{3} \mathrm{O}_{8}$ in the unprospected area.

The average $\mathrm{P}_{2} \mathrm{O}_{5}$ content of the zone is difficult to estimate. Figure 10 shows that it is much higher in the low flatwoods area adjacent to the Peace River than in the higher flatwoods area to the west. Only in the low flatwoods are there large tonnages of aluminum phosphate zone having more than 5 perecent $\mathrm{P}_{2} \mathrm{O}_{5}$.

The best aluminum phosphate zone material in the Fort Meade quadrangle is in the low flatwoods area, where there is about $250-300$

\section{TABLE 7.-Indicated reserves, aluminum phosphate zone}

[Figures from company drilling. For $\mathrm{U}_{3} \mathrm{O}_{8}$ and $\mathrm{P}_{2} \mathrm{O}_{5}$ figures, see table 6]

\begin{tabular}{|c|c|c|c|c|}
\hline \begin{tabular}{l}
\multicolumn{2}{c}{ Location } \\
T. 31 S., R. 24 E \\
T. 32 S., R. 24 E \\
T. 32 S., R. 25 E.
\end{tabular} & $\begin{array}{c}\text { Total acres } \\
600 \\
1,960 \\
920\end{array}$ & $\begin{array}{l}\text { Total long tons } \\
12,200,000 \\
37,700,000 \\
14,000,000\end{array}$ & $\begin{array}{r}\text { Long tons } \\
\mathrm{U}_{3} \mathrm{O}_{8} \\
580 \\
1,880 \\
1,340\end{array}$ & $\begin{array}{r}\text { Long tons } \\
\mathrm{P}_{2} \mathrm{O}_{3} \\
350,000 \\
1,250,000 \\
970,000\end{array}$ \\
\hline Total & 3,480 & $63,900,000$ & 3,800 & $2,570,000$ \\
\hline \multicolumn{5}{|c|}{ [Figures calculated from gamma-ray logs] } \\
\hline Location & $\begin{array}{c}\text { Total acres } \\
9,760 \\
440 \\
680\end{array}$ & $\begin{array}{r}\text { Total long tons } \\
155,000,000 \\
13,800,000 \\
8,200,000\end{array}$ & $\begin{array}{r}\mathrm{eU}_{3} \mathrm{O}_{8} \\
0.008 \\
.008 \\
.009\end{array}$ & $\begin{array}{r}\mathrm{U}_{3} \mathrm{O}_{8} \\
12,400 \\
1,100 \\
750\end{array}$ \\
\hline$---\ldots-\ldots-n--$ & 10,880 & $177,000,000$ & $0.008+$ & 14,240 \\
\hline
\end{tabular}


million long tons of material that contains $5-10$ percent $\mathrm{P}_{2} \mathrm{O}_{5}$ and about 0.009 percent $\mathrm{U}_{3} \mathrm{O}_{8}$.

\section{PHOSPHATE RESOURCES IN THE HAWTHORN FORMATION}

Data on the phosphate content of only the top few feet of the Hawthorn Formation are available- either the upper part or the calcareous clay of the lower part (table 8). The two deep drill holes (table 2) indicate only that phosphate nodules in the Hawthorn Formation are mostly fine grained.

The tonnage figures in table 8 are for residual material and are higher than the tonnage of phosphate in the unweathered Hawthorn. A figure of about 180 tons per acre-foot (about half the tonnage shown in table 8) was used to compute reserves. The Hawthorn Formation probably averages about 100 feet in thickness and contains about 18,000 tons of phosphate nodules per acre.

The Hawthorn Formation underlies the entire Fort Meade quadrangle, and if half of the total area is underlain by 18,000 tons per acre of phosphate, then the Hawthorn Formation in the quadrangle contains about $1.5 \times 10^{9}$ tons of phosphate.

The average grade of the pebble is about 40 percent BPL; that of the concentrate is about 60 percent $\mathrm{BPL}$, so the average grade of the phosphate particles in the Hawthorn Formation is about 55 percent BPL.

\section{MINE AND TRACT DESCRIPTIONS}

\section{SOUTH PIERCE MINE}

The South Pierce mine of the American Agricultural Chemical Co. is in secs. 29-33, T. 31 S., R. 24 E.; sec. 36, T. 31 S., R. 23 E.; secs. 1 and 2, T. 32 S., R. 23 E.; and secs. 3-6, T. 32 S., R. 24 E., Polk County.

Mining probably started in the late 1920's or early 1930's and continued until 1962. All the mining at this tract was by the American Agricultural Chemical Co. Draglines were used to move

TABLE 8.-Data on tonnage and grade of phosphate in the Hawthorn Formation [Duta from 77 samples, from company drill holes. Samples ranged in thickness from 3 to $13 \mathrm{ft}$ and averaged $51 / 2 \mathrm{ft}]$

\begin{tabular}{|c|c|c|c|c|c|c|}
\hline & \multicolumn{2}{|c|}{ Tons per acre-foot } & \multicolumn{2}{|c|}{ Percent $\mathrm{P}_{2} \mathrm{O}_{5}$} & \multicolumn{2}{|l|}{ Percent U1 } \\
\hline & Range & $\begin{array}{c}\text { A ver- } \\
\text { age }\end{array}$ & Range & $\underset{\text { age }}{\text { A ver- }}$ & Range & $\underset{\text { age }}{\text { A ver- }}$ \\
\hline $\begin{array}{l}\text { Pebble } \\
\text { Concentrate }\end{array}$ & $\begin{array}{r}10-338 \\
173-497\end{array}$ & $\begin{array}{r}94 \\
268\end{array}$ & $\begin{array}{r}\text { 5. } 1-31.0 \\
28.3-32.0\end{array}$ & $\begin{array}{l}20.2 \\
30.6\end{array}$ & $\begin{array}{r}0.005-0.012 \mid \\
\text { No data }\end{array}$ & 0.009 \\
\hline
\end{tabular}

1 Only 14 samples were analyzed for $U$. 
overburden at the No. 11 washer (South Pierce mine), but the phosphate rock was mined by hydraulic giants in the bottom of the pit. Large suction pumps and pipelines were used to transport the phosphate matrix to the washer.

Only the pebble and the coarse concentrate $(-14+35$ mesh) were recovered at the No. 11 washer. No fine phosphate was obtained and no flotation cells were used, because the cell concentrate fraction $(-35+150 \mathrm{mesh})$ is only 1 or 2 percent of the total-too little to justify the cost of a flotation recovery plant.

\section{STRATIGRAPHY}

The No. 11 washer of the South Pierce mine was open during the time of the field investigation. Data on stratigraphy are from the examination of the mine and, for areas that have not been mined, are supplemented by drill-hole data. The area has a surficial cover of Pleistocene sand; the only outcrops are in the mine pits.

\section{HAWTHORN FORMATION}

The oldest rock exposed in the mine pits was the top few feet of the upper part of the Hawthorn Formation. Drilling indicates that limestone or calcareous clay of the lower part of the Hawthorn underlies the upper part, and that the upper part ranges in thickness from 0 to about 20 feet and thins toward the south. The upper part is a massive greenish-gray to gray, fine clayey sand or sandy clay, containing tan, brown, and black, fine phosphate nodules. Screen analyses for one sample of the upper part show that it is a well-sorted fine sand, containing only a small amount of clay (table 9 ).

The upper part of the Hawthorn Formation is included in the matrix where the phosphate is abundant and of high enough grade. The tonnage of phosphate nodules and the phosphate content of the

TABLE 9.-Screen tests and chemical and radiometric analyses, upper part of the Hawthorn Formation, $S E 1 / 4 S W 1 / 4$ sec. 32, T. 31 S., R. 24 E., No. 11 washer

[Sereen tests by Thornton and Co., Tampa, Fla., under contract to U.S. Geol. Survey. Analysts (U.S. Geol. Survey): F. S. Grimaldi $\left(\mathrm{P}_{2} \mathrm{O}_{5}, \mathrm{~F}, \mathrm{U}-\right.$ chemical); J. J. Warr, Jr., and F. J. Flanagan (eU-radiometric)]

\begin{tabular}{|c|c|c|c|c|c|c|}
\hline \multirow{2}{*}{$\begin{array}{l}\text { Sample and } \\
\text { lab No. }\end{array}$} & \multirow{2}{*}{ Mesh fraction } & \multirow{2}{*}{$\begin{array}{l}\text { Weight } \\
\text { percent }\end{array}$} & \multicolumn{4}{|c|}{ Analyses, in percent } \\
\hline & & & $\mathrm{P}_{2} \mathrm{O}_{5}$ & $\mathbf{F}$ & $\mathbf{U}$ & $\mathrm{eU}$ \\
\hline $\begin{array}{r}747-1 \mathrm{a}_{\ldots} \ldots \\
-1 \mathrm{~b}_{\ldots} \\
-1 \mathrm{c} \ldots \\
-1 \mathrm{~d} \\
-1\end{array}$ & $\begin{array}{l}+14 \\
-14+35 \\
-35+150 \\
-150 \\
\text { Head }\end{array}$ & $\begin{array}{r}5.4 \\
11.8 \\
76.5 \\
6.3 \\
100.0\end{array}$ & $\begin{array}{r}29.1 \\
9.5 \\
2.7 \\
4.7 \\
5.1\end{array}$ & $\begin{array}{r}2.57 \\
1.06 \\
.31 \\
.13 \\
.48\end{array}$ & $\begin{array}{r}0.014 \\
.003 \\
.001 \\
.001 \\
.001\end{array}$ & $\begin{array}{r}0.015 \\
.003 \\
.001 \\
.002\end{array}$ \\
\hline
\end{tabular}

\footnotetext{
1 Flotation tests made of this fraction. No concentrate was recovered.
} 
nodules in the sample of table 9 show that this particular sample was not a part of the matrix. It was not included in the material mined.

Cream-colored, white, or yellow, sandy, clayey limestone, or calcareous clay residual from limestone, underlies the upper part of the Hawthorn. The limestone contains minor amounts of fine black and brown phosphate nodules. The calcareous clay may be a part of the matrix, but at the No. 11 washer only the lower unit of the Bone Valley Formation was considered to be matrix.

The contact of the upper part of the Hawthorn Formation with the overlying lower unit of the Bone Valley Formation is disconformable. At every locality examined in the pits of the No. 11 washer the top fow inches of the clayey sand of the Hawthorn Formation was crowded with vertical animal borings which were filled with the phosphorite of the lower unit of the Bone Valley Formation $(\log B)$. The change in lithology between the two formations also indicates a change in the history of deposition and sedimentation.

\section{Loo B.-Mine-face section, No. 11 washer, South Pierce mine, SW1/4SW1/4 sec. 32, T. 31 S., R. $24 \mathrm{E}$.}

[Modified from lithologic section by H. M. Icke and R. H. Stewart; uranium analyses by H. B. Kessler ]

Recent or Pleistocene :

Windblown sand:

Thickness

Sand, loose, white, fine

(feet)

Pleistocene :

Terrace sand :

Sand, loose, fine to medium, black at top, grades to brown at base -- 7

Pliocene :

Bone Valley Formation (upper unit) :

Sand, clayey, gray-brown $(0.002$ percent $U)$

Sand, very clayey, blue-green; contains trace amounts of leached soft, white phosphate nodules at the top $(0.002$ percent $U)$-.-..-

Sand, slightly clayey, green; contains unleached brown and black phosphate in small amounts $(0.002$ percent $U)$

Sand, gray ; mottled with green; contains trace amounts of finegranule-size phosphate $(0.003$ percent $U)$

\section{1}

Valley Formation (lower unit) :

Sand, loose, gray-brown; abundant black coarse phosphate $(0.002$

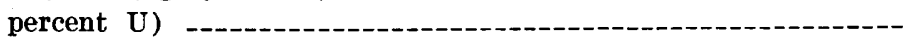

Sand, loose, gray, distinctly crossbedded; black and brown phosphate $(0.002$ percent $U)$-...----

Sand, brown, distinctly crossbedded; trace of clay; very abundant black and brown coarse phosphate (fossils listed on p. 16). Abundant bones and teeth at base $(0.008$ percent $U)$-.-.---_- 6

Total Bone Valley Formation 
Lot B.-Mine-face section, No. 11 washer, South Pierce mine, SW1/4SW1/4 sec. Miocene: 32, T. 31 S., R. $24 E .-$ Continued

Hawthorn Formation (upper part) :

Sand, clayey, fine to very fine, greenish-gray. Trace of mediumgrained phosphate nodules. Surface of the clayey sand is filled with small circular animal borings. The borings extend a few inches down into the clayey sand and are filled with brown phosphorite of the overlying unit $(0.002$ percent $U)$ -

Part of Hawthorn Formation

The Bone Valley-Hawthorn contact at the South Pierce tract can be distinguished in drill cores. At the locality of drill hole $\mathrm{C}$ the contact is at the break between gray-green clayey sand and loose white and gray sand. The matrix at this drill hole is composed of rocks of both the Bone Valley and the Hawthorn Formations. Because this is a log of a hand-auger drill, no bedding could be determined from the cuttings.

At the locality of drill hole D (p. 54) a coarse sand or fine conglomerate of the Bone Valley rests directly on limestone of the Hawthorn Formation, and the contact is a very sharp lithologic break.

Log C.-Drill hole in $S E 1 / 4 S E 1 / 4$ sec. $29, T .31$ S., $R .24 E$.

Pleistocene :

Terrace sand :

Thickness (feet)

Sand, loose, white, fine 7

Pliocene :

Bone Valley Formation (upper unit) :

Sand, clayey, gray, medium-grained

Sand, gray to white, medium to fine; slightly clayey at top to clayey at base. Clay is white and kaolinitic.

Bone Valley Formation (lower unit) :

Sand, clayey, white; soft, white phosphate. Phosphate is black at lower contact (leached lower unit)

Sand, white and gray, medium-grained; very slightly clayey at top to loose at base; abundant black and brown and some white coarse-sand- to granule-size phosphate nodules (part of matrix) --

Total Bone Valley Formation.- 21

Miocene :

Hawthorn Formation (upper part) :

Sand, clayey, gray-green; fine-granule- to coarse-sand-size brown and black phosphate (part of matrix)

Sand, clayey, gray-green ; trace amounts of fine-grained brown phosphate (not a part of the matrix)

Part of Hawthorn Formation

Bottomed in material like the above. 
LoG D.-Drill hole in $S E 1 / 4 S E 1 / 4$ sec. $31, T .31$ S., $R .24 E$.

Pleistocene :

Terrace sand :

Sand, loose, light-gray, fine

Pliocene :

Bone Valley Formation (upper unit) :

Sand, very slightly clayey, gray-tan, fine to medium. Clay is white

Sand, slightly clayey, tan ; fragments of aluminum phosphate-cemented sand

Sand, very slightly clayey, tan-gray, medium to coarse

Sand, very slightly clayey, tan; trace amounts of soft, white phosphate

Bone Valley Formation (lower unit) :

Sand, very slightly clayey, gray, coarse white phosphate at top and brown and black phosphate at base. Phosphate is coarse-sand to granule size

Sand, loose, gray ; very abundant coarse-sand- to granule-size brown and white phosphate

Total Bone Valley Formation

Miocene :

Hawthorn Formation (lower part) :

Limestone (or dolomite), white, soft, sandy and clayey; trace amounts of fine-sand-size brown phosphate

Hole bottomed in rock too hard to penetrate-hard limestone of the Hawthorn Formation.

\section{BONE VALLEY FORMATION}

Both the lower and upper units of the Bone Valley extend throughout the South Pierce tract. The lower unit, as seen in the mine pits, is a gray sand containing a small amount of clay and black and brown coarse-sand to granule size phosphate. In many places a conglomerate of coarse phosphate and phosphatized bones and teeth rests on the fine clayey sand of the Hawthorn. The lower part of the lower unit of the Bone Valley is crossbedded, and it contains fossil bones and teeth identified as Pliocene in age $(\log B$ and p. 16).

The upper part of the lower unit is a light-gray sand of quartz and black and brown phosphate; it is more massive and contains less phosphate than the lower part. Graded bedding (pl. 7) was seen at some of the mine-face sections. In places the upper part of the lower unit contains so little phosphate that it is not minable. The thickness of the lower unit of the Bone Valley Formation is 0 to about 40 feet and averages about 15 feet.

The upper unit of the Bone Valley Formation is a gray, gray-green, or green clayey sand containing small amounts of black and brown phosphate and a few thin, discontinuous beds of green sandy clay. 
The contact between the upper and lower units is gradational and is identified as the point where the phosphate content is too low to be economic. The upper unit ranges in thickness from 8 to about 30 feet and averages about 20 feet. The unit is massive, compared with the crossbedded lower unit, and bedding is indicated by the lenticular clay beds.

\section{TERRACE DEPOSITS}

Well-sorted, medium-grained white or gray quartz sand of Pleistocene age blankets the surface. Organic material stains the sand black at the top, and iron oxide stains it brown at a few places. The thickness ranges from 3 to about 25 feet and averages about 9 feet. The contact of the sand of Pleistocene age and the upper unit of the Bone Valley Formation is picked as the highest occurrence of clayey sand in the section. This is arbitrary, as no fossils have been found in either unit, but it is the only lithologic break in this part of the section.

Windblown sand and swamp deposits at the surface are probably Recent, but these deposits are very thin and are erratic in distribution; no attempt has been made to distinguish them individually.

\section{ECONOMIC GEOLOGY \\ CALCIUM PHOSPHATE ZONE}

The calcium phosphate zone is present at most drill holes in the tract, and it consists of the lower unit of the Bone Valley Formation and the upper part of the Hawthorn Formation. Thin calcareous clay, residual from limestone of the lower part of the Hawthorn Formation, is present at some of the drill holes. Only the lower unit of the Bone Valley Formation was mined; mining stopped on the clayey sand of the upper part of the Hawthorn Formation. The difference in total $\mathrm{P}_{2} \mathrm{O}_{5}$ content between the lower unit of the Bone Valley Formation and the upper part of the Hawthorn Formation is shown on plate $7 A$ (note the difference in analysis between samples 1 and 2). The difference in the weight percent of +14 mesh phosphate nodules between the two formations at this locality is indicated on plate $7 B$, which shows a very noticeable rise in the amount of the pebble fraction between samples 1 and 2 .

The concentrate fraction of the calcium phosphate zone in the South Pierce tract is negligible (pl. $7 D)$.

\section{ALUMINUM PHOSPHATE ZONE}

The aluminum phosphate zone is less than 3 feet thick in the southern part of the tract (pl. 8), and it is so low in $\mathrm{P}_{2} \mathrm{O}_{5}$ content (fig. 10) over most of the tract that it is unlikely to ever be mined.

Over most of the tract only the upper unit of the Bone Valley Formation has been leached to form the aluminum phosphate zone (pl. $7 A$ ), and at many drill holes only the top part of the upper unit 
is leached (pl. $7 B$ ). In some areas, however, leaching extended into the lower unit of the Bone Valley Formation $(\log \mathrm{E})$. The mineralogy of the aluminum phosphate zone is shown on $\log \mathrm{E}$.

Uranium and phosphate are both concentrated in the slime fraction of the aluminum phosphate zone in the South Pierce tract. The head samples are not economic at most places, but if the slime fraction of the zone could be recovered, the aluminum phosphate zone might be economic.

LoG E.-Mine-face section in NW1/4NE1/4 sec. $31, T .31$ S., R. 24 E., South Pierce mine

[Lithology by J. B. Cathcart, L. V. Blade, and D. C. Alverson. Mineralogy of the -200 mesh fraction by X-ray diffractometer by $\mathrm{L}$. V. Blade]

Pleistocene:

Terrace sand :

Thickness $(f t$.

Sand, loose, white; gray at top (not sampled)

Pliocene :

Bone Valley Formation:

Upper unit (leached) :

Clay, sandy, gray. Kaolinite is the most abundant mineral, wavellite and crandallite are the phosphate minerals 2. 0

Sand, slightly clayey, gray. Wavellite and crandallite are the most abundant minerals, the clay mineral is kaolinite-

Sand, clayey, gray. Kaolinite is very abundant, crandallite and wavellite are the phosphate minerals, and a trace of montmorillonite is present

Lower unit (leached) :

Sand, clayey, white; nodules of soft, white phosphate. Crandallite, wavellite, and kaolinite are abundant, but apatite and montmorillonite are present

Base of sampled section. Unweathered phosphorite below this sample.

\section{CONSOLIDATED TRACT}

The Consolidated tract is in secs. 7-11, 15-25, and 26-34, T. 32 S., R. 24 E., in southern Polk County. Late in 1953, 56 holes were drilled in this tract by the American Agricultural Chemical Co., under contract to the U.S. Atomic Energy Commission. A single sample, representing all the economic phosphate, was taken at each drill hole, and a single sample of the aluminum phosphate zone was taken at each of 49 of the drill holes. All samples were analyzed by the company; the average results are shown in tables 4 and 6 . Operation of the Palmetto mine, on the Consolidated tract, was begun in mid-1961.

\section{STRATTGRAPHY}

Small chip samples, representing each foot of drilling, were collected at each drill hole. Stratigraphic interpretation is based on lithologic logs made by the writer from these chip samples, using a binocular microscope. 
Stratigraphic relations in the Consolidated tract are shown by logs F and $\mathrm{G}$, section $C-C^{\prime}$ (pl. 1), and holes 5-14 in section $A-A^{\prime}$ (pl. 1). The surface is covered by a blanket of quartz sand assigned to the Pleistocene. Mining at the tract had not yet begun when the geologic work was done.

\section{HAWTHORN FORMATION}

All drill holes in the tract bottomed on limestone or calcareous clay of the lower part of the Hawthorn Formation. In the southern part of the tract, only the lower part of the Hawthorn is present, but in the northern part of the tract, the upper part of the Hawthorn overlies hard limestone of the lower part at many of the drill holes (sections $A-A^{\prime}, C-C^{\prime}$, pl. 1). The lower part consists of cream, yellow, or white sandy and clayey limestone or dolomite or calcareous clay residual from the carbonate rock. The sand fraction of the lower part consists of fine to very fine quartz grains, and black or brown phosphate grains. Calcareous clay is present at most drill holes in the southern part of the tract and ranges in thickness from 0 to about 10 feet.

The upper part of the Hawthorn is a green or green-gray clayey sand or sandy clay containing black, coarse-sand- to fine-granule-size phosphate nodules. Phosphate is abundant enough that the upper part is included in the matrix at some drill holes. The upper part of the Hawthorn is $0-12$ feet thick.

Drill holes are so widely spaced that no attempt was made to map the upper part of the Hawthorn Formation. It is present at most drill holes in the northwest quarter of T. 32 S., R. 24 E., and is absent to the south.

\section{BONE VALLEY FORMATION}

LoG F.-Drill hole in $N W 1 / 4 N W 1 / 4$ sec. $17, T$. 32 S., R. $24 E$.

[Drilled by the American Agricultural Chemical Co., under contract to the U.S. Atomic Energy Comm. Drill hole 13, section $A-A^{\prime}$, pl. 1]

Pleistocene :

Terrace sand :

Sand, loose, white to light-gray, fine $(f t)$

Pliocene :

Bone Valley Formation (upper unit) :

Clay sandy, white; sand fraction consists of medium grains.

Sand, very clayey, gray-green ; sand fraction consists of fine grains_._ 5



Sand, slightly clayey, medium-grained; brown at top to yellow gray at base

Sand, slightly clayey, tan-gray; trace amounts of black phosphate_- 6 
LOG F.-Drill hole in NW1/4 NW1/4 sec. 17, T. 32 S., R. 24 E.-Continued

\section{Pliocene-Continued}

Bone Valley Formation (lower unit) :

Sand, clayey, light- to yellow-gray; black, gray, tan, and minor white coarse-sand- to granule-size phosphate nodules

Conglomerate, sandy, of coarse-granule-size gray and tan phosphate. Sand fraction is mostly quartz, but includes minor black, tan, and gray phosphate. Driftrock

Total Bone Valley Formation

Miocene :

Hawthorn Formation (upper part) :

Clay, very sandy, yellowish-gray; abundant gray coarse-sand-size, and minor granule-size, phosphate

Hawthorn Formation (lower part) :

Limestone (or dolomite), sandy, cream-colored; fine-sand-size brown phosphate grains and trace amounts of gray granule-size phosphate

Part of Hawthorn Formation

Base of drill hole.

LoG G.-Drill hole in $S W 1 / 4 S W 1 / 4$ sec. $17, T$. 32 S., $R .24 E$.

[Drilled by American Agricultural Chemical Co., under contract to the U.S. Atomic Energy Comm. Drill hole 10, section $A-A^{\prime}$, pl. 1]

Pleistocene :

Terrace sand :

Sand, loose, gray, medium to fine

Pliocene :

Bone Valley Formation (upper unit) :

Sand, slightly clayey, gray, medium to fine

Sand, slightly clayey, gray, medium to coarse; small amounts of soft, white and tan phosphate grains

Bone Valley Formation (lower unit) :

Sand, slightly clayey to clayey, dark-gray-green; coarse-sand- to granule-size phosphate nodules, black and gray nodules abundant, brown nodules sparse

Total Bone Valley Formation._.

Miocene :

Hawthorn Formation (lower part) :

Clay, slightly sandy, cream-colored; slightly calcareous at top, increasingly calcareous with depth; brown, and some black, gray, and white fine-grained phosphate. Grades into unit below

Limestone, sandy, buff; minor fine to very fine brown phosphate grains

Part of Hawthorn Formation

Bottom in rock too hard to penetrate (limestone of the Hawthorn Formation). 
Both the upper and lower units of the Bone Valley extend throughout the Consolidated tract. They are absent only along Little Payne Creek, where quartz sand of Pleistocene age rests on limestone of the Hawthorn Formation (pl. 1).

The lower unit is a dark-gray or gray-green sand or clayey sand containing very abundant coarse-sand- to granule-size black and brown phosphate nodules. Very little fine-grained phosphate is present; the pebble fraction is much more abundant than the concentrate fraction in all but one of the samples from the drilling. The lower unit ranges in thickness from zero to slightly more than 20 feet and averages about 12 feet.

The contact of the lower unit of the Bone Valley Formation with the underlying Hawthorn Formation is disconformable. The Bone Valley rests on the upper part of the Hawthorn Formation in the northern part of the tract and on limestone in the southern part. Phosphate conglomerate at the base of the lower unit rests on hard limestone of the Hawthorn Formation at several localities (drill hole 6 , section $A-A^{\prime}$, pl. 1).

The contrast in lithologies at the Bone Valley-Hawthorn contact is very marked through the tract. The lower unit of the Bone Valley is coarse grained; the Hawthorn is fine grained. The phosphate in the Hawthorn consists of fine to very fine particles; in the Bone Valley it is coarse-sand to granule size. The contact between the two units can be identified easily from drill-hole cuttings. For example, at drill hole F, the driftrock, or basal conglomerate of the Bone Valley Formation, rests on yellow-gray sandy clay of the upper part of the Hawthorn Formation. At drill hole H, driftrock rests on calcareous clay residual from the underlying limestone of the lower part of the Hawthorn Formation, and at drill hole G, a slightly clayey sand of course phosphate and quartz (almost driftrock) rests on calcareous clay that grades downward into the underlying limestone.

The upper unit of the Bone Valley Formation is a gray, light-gray, white, or light-greenish-gray clayey sand that contains small amounts of phosphate nodules. Phosphate nodules are present only near the bottom of the unit. At many drill holes they are fresh appearing, black or brown, and apparently unleached. The upper unit ranges in thickness from 0 to about 20 feet, and averages about 12 feet.

Log H.-Drill hole in the $S W 1 / 4 N W 1 / 4$ sec. $16, T$. 32 S., R. $24 E$.

[Drilled by the American Agricultural Chemical Co., under contract to the U.S. Atomic Pleistocene :

Terrace sand :

Sand, loose, gray, fine to medium 
Log H.-Drill hole in the $S W 1 / 4 N W 1 / 4$ sec. 16, T. 32 S., R. 24 E.-Continued Pliocene :

Bone Valley Formation (upper unit) :

Clay, gray; very sandy at top, grades downward to clayey sand. Quartz-sand fraction is fine to medium at top, coarse at base. Traces of aluminum phosphate-cemented sand (sandrock) _.-_ 5.0

Clay, yellow-gray; sandy at top, grades downward to clayey sand

Sand, very slightly clayey, gray; trace of soft, white dull phosphate. Phosphate grains more abundant at base

Bone Valley Formation (lower unit) :

Sand, very slightly clayey, gray-white; white, gray, brown, and black phosphate. Contact with unit above is gradational. Phosphate particles are much more abundant at the base of the unit

Sand, very slightly clayey, gray-brown; brown and minor white phosphate. Phosphate is granule and coarse-sand size and increases in amount downward, whereas the clay decreases

Sand, gray-brown, medium-grained ; coarse-sand- to granule-size brown phosphate. Driftrock

Total Bone Valley Formation

Miocene :

Hawthorn Formation (lower part) :

Clay, sandy, calcareous, cream-gray ; coarse-sand-size, some finesand-size, and minor granule-size brown and black phosphate nodules

Limestone or (or dolomite), buff, sandy; some coarse-sand-size brown phosphate nodules, and fine-sand-size brown and black phosphate grains. Contact with the unit above is gradational _- . 2士

Part of Hawthorn Formation 1.2

\section{TERRACE DEPOSITS}

Quartz sand of Pleistocene age covers the surface throughout the Consolidated tract. The contact between the Pleistocene and the underlying upper unit of the Bone Valley Formation is arbitrarily placed at the contact between loose sand and clayey sand.

Hardpan-sand cemented or stained by iron-and "hard iron rock"-sand that is strongly cemented by iron-may be present in the Pleistocene sand or in the clayey sand of the upper unit of the Bone Valley Formation. The distribution of hardpan cannot be accurately mapped in the Consolidated tract, but the available information indicates that the material is restricted to a narrow belt trending south from secs. 3 through 15, and trending somewhat to the southwest through sec. 16, and into secs. 21 and 28 . The reasons for the restricted distribution are not known, but the movement of acid ground 
waters probably controls the distribution of the iron cement, and the surface elevation probably is an additional influence.

Swamp deposits of Recent age are present at the surface in many parts of the area.

\section{ECONOMIC GEOLOGY}

\section{CALCIUM PHOSPHATE ZONE}

The calcium phosphate zone at the Consolidated tract may include rocks of the lower unit of the Bone Valley Formation, rocks of the two parts of the Hawthorn Formation, or a combination of rocks from all these units. At most drill holes the zone consists of rocks of both the Hawthorn and Bone Valley. In the northern part of the tract, however, the zone consists of the lower unit of the Bone Valley Formation and the upper part of the Hawthorn Formation; at some drill holes it also includes the lower part of the Hawthorn. In the southern part of the tract the calcium phosphate zone consists of the Bone Valley Formation and the lower part of the Hawthorn (sections $A-A^{\prime}$, $C-C^{\prime}$, pl. 1).

The matrix, the economic part of the calcium phosphate zone, also commonly includes rocks of both the Bone Valley and Hawthorn Formations, but may be entirely within the Hawthorn Formation or the Bone Valley Formation, or may include only a part of the Bone Valley Formation (section $C-C^{\prime}$, pl. 1).

The distribution of $\mathrm{P}_{2} \mathrm{O}_{5}$ in the size fractions of the calcium phosphate zone at the Consolidated tract is almost exactly the same as the average for the land-pebble phosphate district (Cathcart, 1956). The phosphate products-the pebble and the concentrate-contain about two-thirds of the total $\mathrm{P}_{2} \mathrm{O}_{5}$; the slime fraction contains about onethird; and the quartz sand contains almost no $\mathrm{P}_{2} \mathrm{O}_{5}$ (fig. 12).

The distribution of uranium in the size fractions of the calcium phosphate zone at the Consolidated tract is different from the $\mathrm{P}_{2} \mathrm{O}_{5}$ distribution. Slightly less than half of the total uranium is in the phosphate products, and the rest is in the slime fraction (fig. 12). The quartz sand contains almost no uranium. The slime fraction of the calcium phosphate zone has been enriched in uranium relative эo $\mathrm{P}_{2} \mathrm{O}_{5}$. This is confirmed, at least in part, by the total radioactivity, which reaches a maximum at the top of the matrix and decreases soward the base of the section.

\section{ALUMINUM PHOSPHATE ZONE}

Although the aluminum phosphate zone has been intersected by most drill holes in the tract, the zone is unlikely to become of economic interest except at a few scattered localities. For example, the drill 
LITHOLOGY

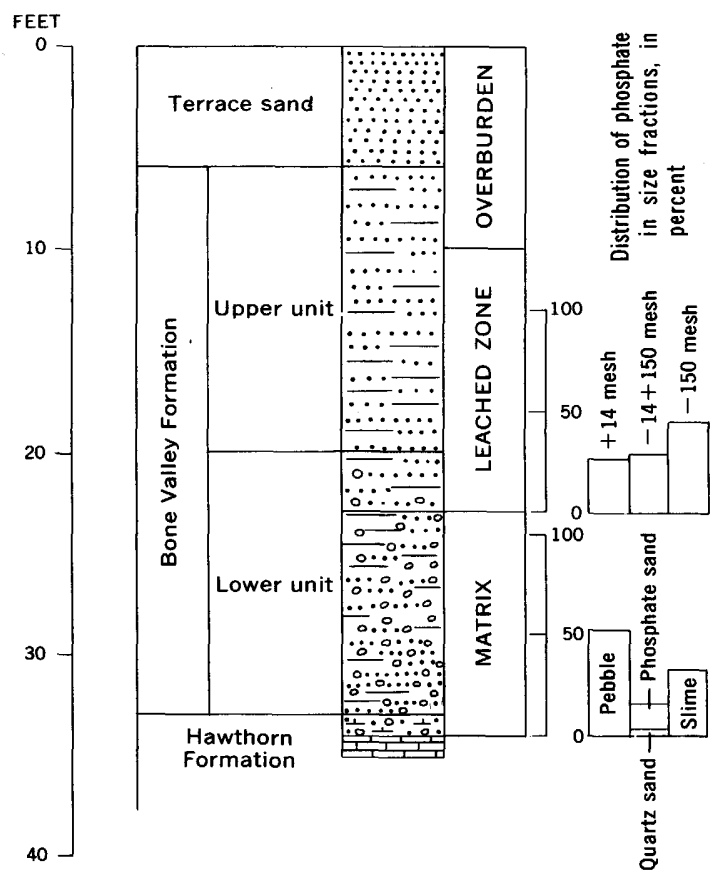

ECONOMIC GEOLOGY

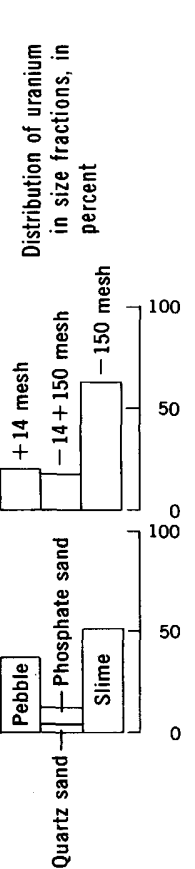

GAMMA-RAY LOG

COUNTS PER MINUTE

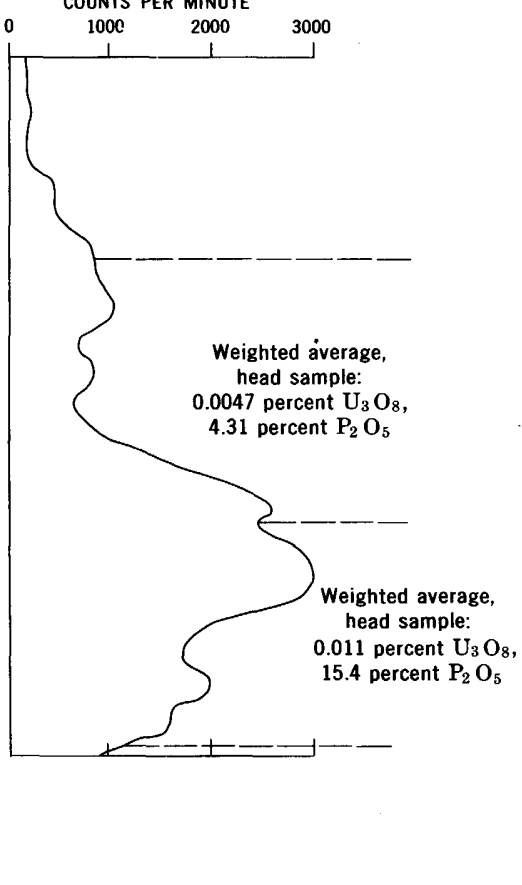

EXPLANATION



Quartz sand

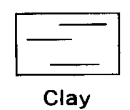

Clay

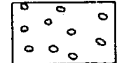

Phosphate nodules

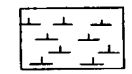

Calcareous clay

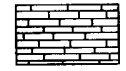

Limestone

Fiaure 12.-Log of drill hole in the $\mathbf{S W} 1 / 4 \mathrm{SE} 1 / 4$ sec. 15, T. 32 S., R. 24 E., Consolidated tract, showing lithology and economic geology. 
holes shown in section $C-C^{\prime}$ (pl. 1) that were sampled for aluminum phosphate zone contained an average of 0.006 percent $\mathrm{U}_{3} \mathrm{O}_{8}$ and 4.01 percent $\mathrm{P}_{2} \mathrm{O}_{5}$. The effect of leaching on the $\mathrm{P}_{2} \mathrm{O}_{5}$ content of the +14 mesh fraction is clearly shown by analyses of samples from the drill holes in section $C-C^{\prime}$ (pl. 1). At hole 3, in the section of aluminum phosphate-cemented sand, the +14 mesh fraction contained 18 percent $\mathrm{P}_{2} \mathrm{O}_{5}$; at hole 4 the soft, white phosphate contained 24 percent $\mathrm{P}_{2} \mathrm{O}_{5}$, and at holes 5 and 6 unleached coarse phosphate contained 28 and 31 percent $\mathrm{P}_{2} \mathrm{O}_{5}$.

Similarly, the aluminum phosphate zone is shown at all holes in section $A-A^{\prime}$ (pl. 1), but the zone is so low in $\mathrm{P}_{2} \mathrm{O}_{5}$ and uranium content that it is of little economic interest-the highest values are from hole 7 , where the uranium content is 0.0056 percent and the $\mathrm{P}_{2} \mathrm{O}_{5}$ content is 4.74 percent.

At some drill holes the aluminum phosphate zone included only the upper part of the upper unit of the Bone Valley Formation. Leaching did not extend to the base of the upper unit (holes 5 , 6 , section $C-C^{\prime}$, pl. $1 ; \log$ I).

LoG I.-Drill hole in SW1/4SW1/4 sec. 8, T., 32 S., R. 24 E.

[Drilling and chemical analysis by American Agricultural Chemical Co., under contract to the U.S. Atomic Energy Comm.]

Pleistocene :

Terrace sand:

Sand, loose, gray, fine to medium

Thickness $(f t)$ Pliocene:

Bone Valley Formation (upper unit) :

Sand, slightly clayey, light-gray-tan; grades downward to clayey sand, and to sandy clay at base-

Clay, sandy, white; mottled with iron stains. Trace of soft, white phosphate

Clay, sandy, gray-and-rust-mottled; grades downward to clayey sand

Sand, loose at top to slightly clayey at base; gray. Contains minor fresh brown and black phosphate grains

(Analyses, in percent, of the upper unit (18 ft) : $\mathbf{P}_{2} \mathrm{O}_{5}=3.2, \mathrm{CaO}=$ $2.8 \mathrm{Al}_{2} \mathrm{O}_{3}=3.4$, and uranium $\left(\mathrm{U}_{3} \mathrm{O}_{3}\right)=0.002$.)

Bone Valley Formation (lower unit):

Sand, very slightly clayey, gray; black and brown granule- and medium-sand-size phosphate

Sand; loose to trace clay; black granule-size phosphate and trace amounts of medium-sand-size phosphate

Total Bone Valley Formation.-_- 25

Miocene :

Hawthorn Formation (upper part):

Sand, clayey, gray-green ; black and white phosphate, mostly medium-sand size, trace of granules 
LoG I.-Drill hole in $S W 1 / 4 S W 1 / 4$ sec. 8, T., s2 S., R. 24 E.-Continued

Miocene-Continued

Hawthorn Formation (lower part) :

Thiokness $(f t)$

Limestone, sandy, clayey, soft, white; trace amounts of black, brown, and gray, fine to very fine phosphate grains

Part of Hawthorn Formation

Bottom in material too hard to penetrate.

All samples of the aluminum phosphate zone at the Consolidated tract were divided by screening into three fractions: +14 mesh, -14 +150 mesh and -150 mesh. Each fraction was analyzed for $\mathrm{P}_{2} \mathrm{O}_{5}$, $\mathrm{CaO}, \mathrm{Al}_{2} \mathrm{O}_{3}, \mathrm{Fe}_{2} \mathrm{O}_{3}$, and $\mathrm{U}_{3} \mathrm{O}_{8}$. These oxides are concentrated in the slime fraction at all drill holes in the tract, but at one drill hole 89-98 percent of the total amount of these oxides is present in the slime fraction (table 10). At this drill hole, the pebble fraction contains higher amounts of the oxides than do the other fractions, but the fraction is so small that only about 1 percent of the analyzed elements are present in the fraction. The $-14+150$ mesh fraction is mostly quartz sand and contains only small amounts of the analyzed oxides. This sample is an extreme example of the concentration of $\mathrm{P}_{2} \mathrm{O}_{5}, \mathrm{CaO}, \mathrm{Al}_{2} \mathrm{O}_{3}, \mathrm{Fe}_{2} \mathrm{O}_{3}$, and $\mathrm{U}_{3} \mathrm{O}_{8}$ in the slime fraction, but it is illustrative of the general tendency toward this type of concentration that prevails throughout the district.

TABLE 10.-Distribution of $\mathrm{P}_{2} \mathrm{O}_{5}, \mathrm{U}_{3} \mathrm{O}_{8}$, and other elements in the screen fractions of the aluminum phosphate zone at a drill hole, Consolidated tract

[Analyses by company chemists, under contract to the U.S. Atomic Energy Comm.]

\begin{tabular}{|c|c|c|c|c|c|c|c|c|c|c|c|}
\hline \multirow{2}{*}{ Mesh fraction } & \multicolumn{5}{|c|}{ Analyses, in percent } & \multirow{2}{*}{$\begin{array}{l}\text { Weight } \\
\text { percent }\end{array}$} & \multicolumn{5}{|c|}{ Distribution, in percent } \\
\hline & $\mathrm{P}_{2} \mathrm{O}_{5}$ & $\mathrm{U}_{3} \mathrm{O}_{8}$ & $\mathrm{Al}_{2} \mathrm{O}_{3}$ & $\mathrm{CaO}$ & $\mathrm{Fe}_{2} \mathrm{O}_{3}$ & & $\mathrm{P}_{2} \mathrm{O}_{5}$ & $\mathrm{U}_{3} \mathrm{O}_{8}$ & $\mathrm{Al}_{2} \mathrm{O}_{3}$ & $\mathrm{CaO}$ & $\mathrm{Fe}_{2} \mathrm{O}_{3}$ \\
\hline $\begin{array}{l}+14 \text { (pebble) } \\
-14+150 \text { (sand) } \\
-150 \text { (slime) }\end{array}$ & $\begin{array}{r}13.79 \\
8.47\end{array}$ & $\begin{array}{r}0.0062 \\
.0000 \\
.0046\end{array}$ & $\begin{array}{r}11.62 \\
.93 \\
10.56\end{array}$ & $\begin{aligned} 8.03 \\
.65 \\
6.23\end{aligned}$ & $\begin{array}{l}2.13 \\
.46 \\
3.28\end{array}$ & $\begin{array}{r}0.5 \\
45.1 \\
54.4\end{array}$ & \begin{tabular}{r|}
1.4 \\
7.8 \\
90.8
\end{tabular} & $\begin{array}{r}1.2 \\
98.0\end{array}$ & $\begin{array}{r}1.2 \\
6.7 \\
92.3\end{array}$ & $\begin{array}{r}1.1 \\
7.9 \\
91.0\end{array}$ & $\begin{array}{r}0.6 \\
10.3 \\
89.1\end{array}$ \\
\hline
\end{tabular}

The part of the aluminum phosphate zone sampled in the drilling at the Consolidated tract included only material that was thought to be potentially economic-the leached zone. The basal contact of the leached zone was always at the top of the economic matrix and the upper contact of the leached zone was determined on the basis of high radioactivity on the gamma-ray log. Typical relations of the aluminum phosphate zone to stratigraphy and economic geology at the Consolidated tract are shown by the log of a drill hole in sec. 15, T. 32 S., R. 24 E. (fig. 12). The top 4 feet of the upper unit of the Bone Valley Formation is included in the overburden. This part of the 
clayey sand is about twice background in radioactivity but is only about half of the average radioactivity of the part of the section that was included in the leached zone. The sampled part of the aluminum phosphate zone (the leached zone) includes the bottom part of the upper unit and the top 3 feet of the lower unit of the Bone Valley Formation.

\section{TILGHMAN TRACT}

The Tilghman tract is in secs. $24-27$ and $34-36$, T. 32 S., R. 24 E., and sec. 30, T. 32 S., R. 25 E., at the south boundary of Polk County. About 400 acres of the 2,150 acres in the tract has been mined. The mining was done by several companies, and over a long time span, in view of the total acreage mined.

The first mining probably was by the Tilghman Phosphate Co., whose offices were at Bowling Green, Fla. Prospect maps of the area indicate that the regional prospecting was done in 1907 and 1908. Sellards (1909, map, pl. XII) showed a mine just to the south of Little Payne Creek, about at the Polk-Hardee County line, which is probably the mine at the head of Olive Branch, a tributary to Little Payne Creek in sec. 34, T. 32 S., R. 24 E. The mining was done by hydraulic methods, or perhaps was done with a dredge, and was for the pebble fraction only. Mining probably continued from 1907 or 1908 through 1911. The Tilghman Phosphate Co. is not listed as a producer in 1912 (Sellards, 1913) ; however, the Interstate Chemical Corp. is listed as a producer of phosphate rock from 1912 through 1916, and as its Florida office was in Bowling Green, it is likely that this company was the successor to the Tilghman Phosphate Co. The Interstate Chemical Corp. probably mined in the area of sec. 27, T. 32 S., R. 24 E., from 1912 through 1916; it is not listed as a producer after 1916.

The Independent Chemical Co., which also had offices at Bowling Green, was probably the successor to the Tilghman Phosphate Co. and the Interstate Chemical Corp. Company prospect maps show that areas in secs. 25 and 34, T. 32 S., R. 24 E., were explored in 1921 and 1923. Independent Chemical Co., which was first listed as a producer in 1919, mined phosphate at the Tilghman tract, probably in secs. 27 and 34, T. 32 S., R. 24 E., until about 1925. Mining in these areas was by hydraulic methods, and only the pebble fraction was recovered. A steam shovel was used to remove the overburden from an area in sec. 25, T. 32 S., R. 24 E., but no phosphate was mined.

The Tilghman tract was prospected by the American Cyanamid Co. in 1951 and 1952. Drill holes were logged by W. J. Carr of the U.S. Geological Survey; $\mathrm{P}_{2} \mathrm{O}_{5}$ data were furnished by the company, and splits of the pebble fraction were analyzed for uranium by the Survey. 


\section{STRATIGRAPHY}

All geologic information regarding the Tilghman tract is from drill holes, because the mined-out areas are completely water filled and inaccessible. Matron (1915, p. 44) gave a stratigraphic section in the Tilghman Phosphate Co. mine at Bowling Green, probably in the SE1/4 sec. 34, T. 32 S., R. 24 E., which is quoted as follows:

Overburden :

Loose gray sand.

Indurated gray sand

Thin, laminated blue clay

Phosphate :

Gray sand with coarse pebbles of phosphate

Gray phosphate conglomerate containing some sand

Blue clay and fine sand with many granules and small pebbles of phosphate

"Bedrock" :

Yellow limestone, locally phosphatic, and with some layers silicified

A typical section, from a lithologic log of a hole drilled in 1952, showing an interpretation of the stratigraphy follows:

Log J.-Drill hole in SE1/4NE1/4 sec. 34, T. 32 S., R. $24 E$.

[Modifled from lithologic log by W. J. Carr, U.S. Geol. Survey]

Pleistocene :

Terrace sand :

Sand, loose, white, fine

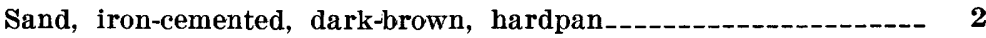

Total terrace sand

Pliocene :

Bone Valley Formation (upper unit) :

Sandstone, gray, indurated; wavellite cement

Sand, clayey, light-gray; a few fragments of aluminum phosphatecemented sand.

Bone Valley Formation (lower unit) :

Sandstone, gray, indurated ; wavellite cement

Sand, gray, clayey; abundant soft, white phosphate. Clay is wavellitic

Clay, light-green, sandy ; fine-sand-size white phosphate grains----

Sand, clayey, cream-colored; brown and white, fine-sand-size phosphate grains.

Sand, light-gray, clayey; abundant coarse-sand- to granule-size brown phosphate and phosphatized limestone granules_--------

Clay, sandy, brown; abundant brown phosphate and phosphatized

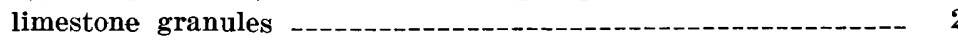

Total Bone Valley Formation_. 
LoG J.-Drill hole in $S E 1 / 4 N E 1 / 4$ sec. 34, T. 32 S., R. 24 E.-Continued

Miocene:

Hawthorn Formation (lower part) :

Thickness

(ft)

Clay, yellow and brown, calcareous; amber and some white, finesand-size phosphate

Part of Hawthorn Formation

3

Hole bottomed in material too hard to penetrate with the hand auger (probably limestone of the Hawthorn Formation).

\section{HAWTHORN FORMATION}

All drill holes in the tract bottomed in calcareous clay or limestone or dolomite of the lower part of the Hawthorn Formation. The limestone is sandy and clayey, white, cream, or yellow, and contains small amounts of phosphate nodules. The calcareous clay is white, cream, or yellow, and at a few localities is green or blue. The phosphate nodules are $\tan$ or brown, and are fine-sand size. They range in abundance from a trace to about 15 percent and average about 5 percent.

At a hole in the NW1/4SE1/4 sec. 34, T. 32 S., R. 24 E., a 1/2-foot-thick bed of olive-green sandy clay containing black phosphate grains is overlain by gray clayey sand containing abundant black phosphate nodules and is underlain by white calcareous bedclay. The olive-green clay bed may be an erosional remnant of the upper part of the Hawthorn Formation. It does not resemble, lithologically, any beds assigned to the Bone Valley in this area, but it does resemble the upper clastic unit of the Hawthorn Formation from the Consolidated tract.

\section{HAWTHORN-BONE VALLEY CONTACT}

The Hawthorn-Bone Valley contact in the Tilghman tract is marked by the abrupt change from white, cream, or yellow-brown calcareous clay or limestone of the Hawthorn to the gray, gray-green, or blue-gray clayey sand of the lower unit of the Bone Valley. The contact is also marked by a consistent change in the phosphate content. The phosphate nodules range from a trace to about 15 percent, by volume, in the Hawthorn Formation and from 20 to 55 percent in the Bone Valley. At about half of the drill holes the basal part of the Bone Valley contains abundant rounded fragments of phosphatized limestone $(\log J)$. In general, the phosphate nodules of the Hawthorn Formation tend to be smaller than $1 \mathrm{~mm}$ in diameter, but those in the Bone Valley are larger than $1 \mathrm{~mm}$ and are as much as several centimeters in diameter. 
BONE VALIEY FORMATION

The lower unit of the Bone Valley Formation, which ranges in thickness from 0 to about 20 feet and averages 10 feet, is a gray or greenishgray clayey sand at almost all drill holes in the tract. Bluish-gray, brownish-gray, and tan clayey sand and sandy clay beds and driftrock and quartz sand are present at a few drill holes. The quartz sand is coarse to very coarse, and the phosphate nodules are mostly coarsesand to granule size. The phosphate nodules are varicolored; they consist of about equal amounts of white, black, brown, and tan nodules, smaller amounts of gray, and a trace of amber. Phosphatized limestone granules are common in the base of the unit.

The upper unit of the Bone Valley, which ranges in thickness from 0 to 35 feet and averages 10 feet, consists mostly of gray or light-gray clayey sand but contains a few beds of greenish-gray or bluish-gray sandy clay and tan, cream, and light-brown clayey sand. Lumps, fragments, or thin beds of sandrock are widespread, and soft dull white phosphate nodules are present at the base of the unit. At one drill hole 12 feet of very hard silica-cemented sand was present at the base of the unit.

At most drill holes all the upper unit and the uppermost part of the lower unit are thoroughly leached $(\log J)$, but fresh black or brown phosphate is present in the base of the upper unit at a few drill holes; therefore, leaching at these holes did not extend to the base of the unit.

\section{TERRACE DEPOSITS}

Massive quartz sand that covers the surface is Pleistocene in age. The sand is medium grained, well sorted, and stained black by organic material or stained brown by iron at many localities. Hardpan is present close to the surface throughout much of the Tilghman tract. At most places the hardpan is within sand of Pleistocene age, but it may be at the contact of the Pleistocene sand and the clayey sand of the upper unit of the Bone Valley Formation and may in part be within the clayey sand.

Swamp deposits and windblown sand at the surface are Recent but have not been separated from the Pleistocene sand.

\section{ECONOMIC GEOLOGY}

\section{CALCIUM PHOSPHATE ZONE}

The calcium phosphate zone at the Tilghman tract includes rocks of the lower unit of the Bone Valley Formation and the lower part of the Hawthorn Formation. Calcareous clay, residual from limestone, is present at most drill holes, but at few places is it more than 1-2 feet thick. The contact between the two units is easily rec- 
ognized, even from drill-hole data, and at most places the residual calcareous clay (bedclay) was not even sampled by the prospecting foreman. Where the unit was sampled the phosphate content of the nodules was low, ranging from 8.43 to 29.45 percent $\mathrm{P}_{2} \mathrm{O}_{5}$, and averaging 24.25 percent. Nodules from the Bone Valley contained 29.42-34.86 percent $\mathrm{P}_{2} \mathrm{O}_{5}$ and averaged 31.73 percent. Thus, although the calcium phosphate zone includes both the Bone Valley and the Hawthorn Formations, the matrix is confined almost entirely to the lower unit of the Bone Valley Formation.

Approximately 500 samples of coarse and fine pebble from 126 drill holes in the Tilghman tract, mostly from the Bone Valley, were analyzed for uranium by the U.S. Geological Survey. Pebble samples from the Hawthorn contained from 0.005 to 0.012 percent uranium, and averaged 0.009 percent; pebble samples from the Bone Valley contained from 0.010 to 0.024 percent uranium, and averaged 0.017 percent. The uranium content of the pebble fraction is low at or close to the streams and is relatively high in the interstream divides (fig. 13).

The isopleths in figure 13 represent tons per acre of uranium in the pebble fraction. The uranium content of the pebble fraction is less than 0.25 tons per acre at Little Payne Creek and its tributaries; it increases away from the stream to a maximum of more than 1 ton per acre in four small areas. The highest tonnages are at or close to the mined area, which contained the largest tonnages of the pebble fraction which in turn is highest in uranium.

\section{ALUMINUM PHOSPHATE ZONE}

The aluminum phosphate zone is present throughout the Tilghman tract except along the course of Little Payne Creek and its tributaries. The zone cuts across formation contacts (fig. 14). At most drill holes the aluminum phosphate zone and this upper unit of the Bone Valley Formation are nearly the same, at least for practical mining purposes. However, in detail, the aluminum phosphate zone may extend into the lower unit (hole 4, fig. 14), or the base of the zone may not reach the base of the upper unit.

The potentially economic part of the aluminum phosphate zone is present only at drill sites adjacent to Little Payne Creek (holes 3, $4,6$, fig. 7,14$)$. At hole 3 the bottom half of the zone may be economic; the uranium content increases toward the base of the zone, particularly in the slime fraction. At hole 4 the entire upper unit of the Bone Valley Formation is potentially economic. The dull white phosphate nodules of the top part of the lower unit are so low in phosphate content that the company classified this part of the lower unit as overburden. This top part of the lower unit is probably a 


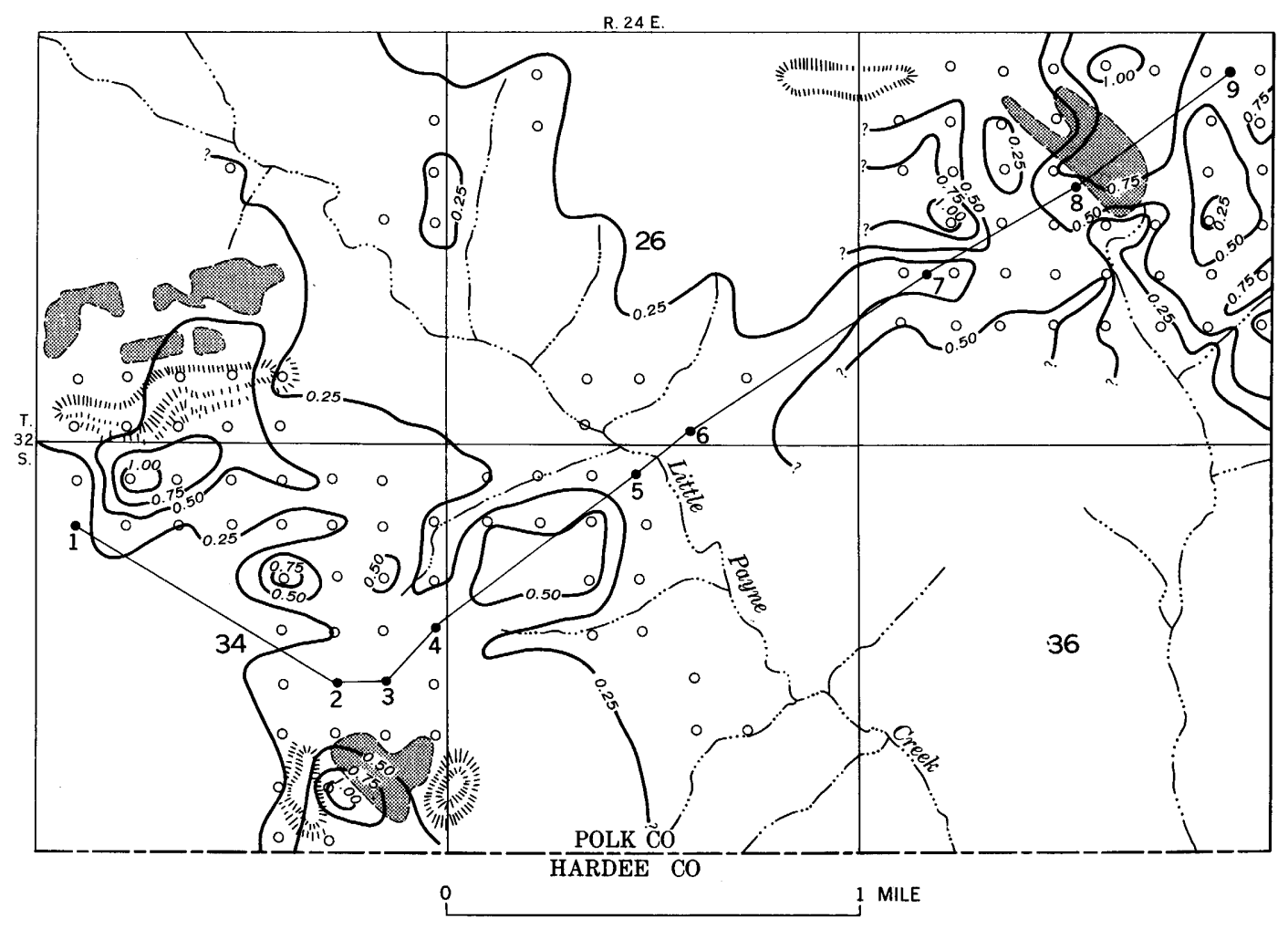

Showing tons per acre of uranium in the pebble fraction. Contour interval 0.25 tons per acre

$$
\circ
$$

Drill-hole location for which tonnage data were available

3 - 4

Line of section, fig:ure 14

Mined- out areas

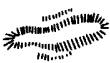

Overburden dumps

FrguRe 13.-Uranium distribution in the pebble fraction of the calcium phosphate zone, Tilghman tract, secs. 25-27, 34-36, T. 32 S., R. 24 E. 


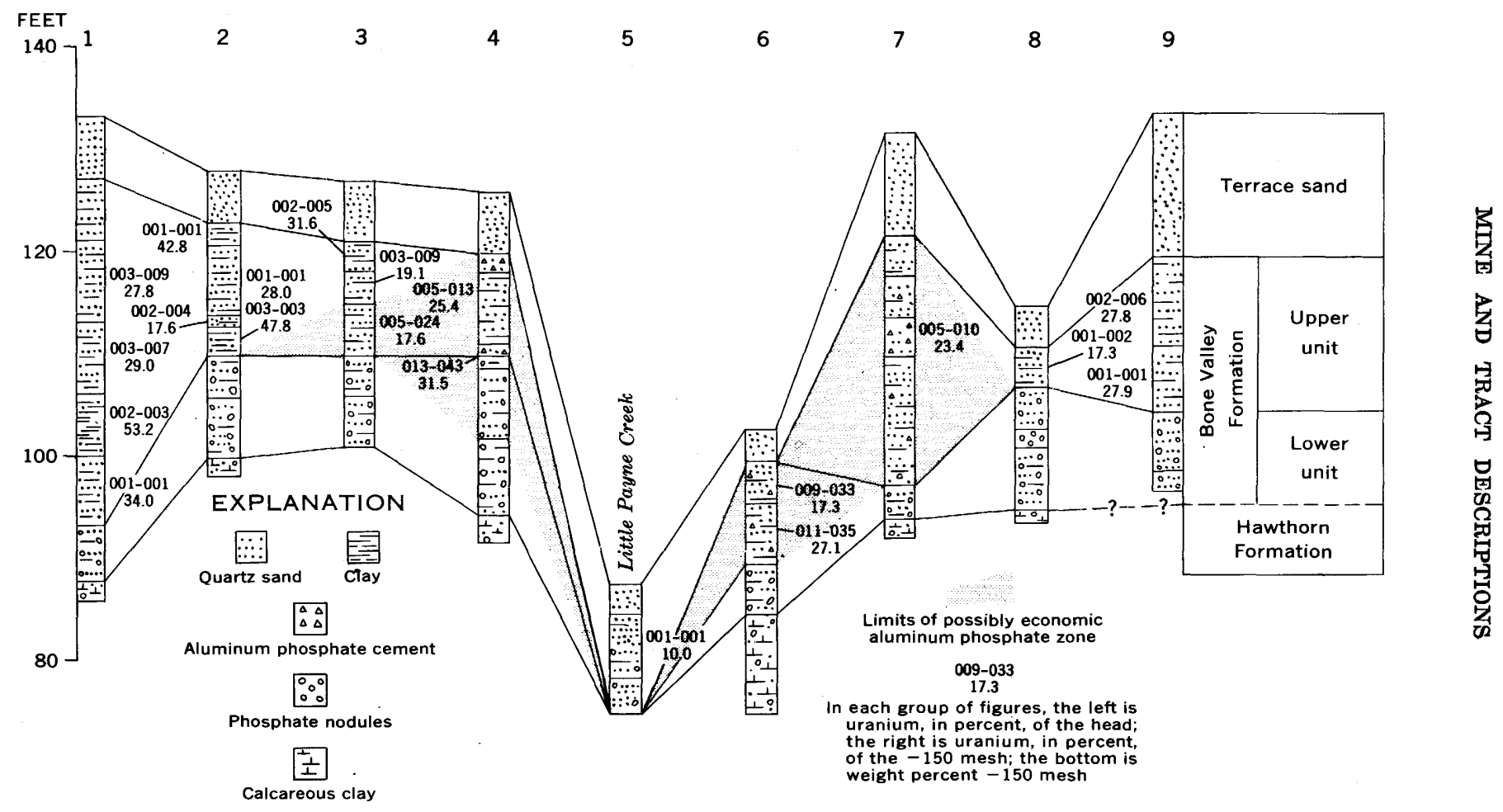

FIGURE 14.-Logs of drill holes (locations in fig. 13) in the Tilghman tract, showing stratigraphy and economic geology. 
part of the aluminum phosphate zone. At holes 6 and 7 all the upper unit of the Bone Valley Formation is potentially economic aluminum phosphate zone. At hole 7 the lower part of the upper unit contains fresh black phosphate grains; leaching stopped above the base of the upper unit. This unleached material is actually in the calcium phosphate zone, but the company considers it overburden or the base of the leached zone.

During drilling at the Tilghman tract 36 samples of the aluminum phosphate zone were taken. These samples were washed over 14-, 35-, and 150-mesh screens, and samples of the material retained on each screen plus a sample of the -150 -mesh material were analyzed for uranium by the Survey.

The +14 mesh fraction consists principally of fragments of sand cemented by wavellite; some coarse quartz grains may also be present, and small amounts of soft, white leached phosphate are almost always present. At a few drill holes fragments of iron-cemented sand were noted in this fraction, and at two localities fresh black phosphate was noted. The pebble fraction averages about 4 percent by weight of the sample and contains an average of 0.008 percent uranium; 8 percent of the total uranium in the sample is in the +14 mesh fraction.

The $-14+35$ mesh fraction, 11 percent of the total, contains only 0.002 percent uranium and consists largely of quartz sand, small amounts of white phosphate, and fragments of aluminum phosphatecemented sand. About 6 percent of the total uranium is in this fraction.

The $-35+150$ mesh fraction, 59 percent of the total, contains less than 0.001 percent uranium, about 16 percent of the total uranium in the sample. The fraction is almost entirely quartz sand and contains only traces of phosphate and phosphate-cemented sand.

The -150 mesh fraction, 26 percent of the total, contains 0.010 percent uranium, or about 70 percent of the total uranium in the aluminum phosphate zone. The fraction consists of clay and small amounts of silt and fine sand. The silt- and sand-size particles are mostly quartz, but some phosphate is present.

The uranium content of the zone is low near the streams and high in the divides; in the Tilghman tract the zone is so low in uranium content that it is probably not economic.

\section{WALDO-WATSON MINES}

The Waldo and Watson mines of Swift \& Co. are in secs. 31 and 32 , T. 31 S., R. 25 E., and secs. 3-10 and 16-18, T. 32 S., R. 25 E., Polk County. The mines are adjacent to and west of the Peace River and just south of the city of Fort Meade. 
The Waldo mine, in the northern part of the area, in T. 31 S., R. 25 E., and in sec. 6. T. 32 S., R. 25 E., was mined by draglines from 1925 to 1937 . Pebble was recovered in a washer plant, but flotation concentrate was recovered only from 1935 to 1937 . Mining was finished before the Survey began the investigation of the land-pebble phosphate district, but the drill records are similar to those from the Watson mine, and the discussion of the geology of the Watson mine probably is also applicable to the Waldo mine.

The Watson mine, which was opened in 1937, was in operation in 1964. Both pebble and concentrate fractions are produced there. The plant recovers the coarse flotation material $(-16+48$ mesh) in underwater agglomerating screens (Siems, 1951, p. 399).

\section{STRATIGRAPHY}

The discussion of the stratigraphy is based on sections taken at the mines and on information from drilling in 1953 under contract to the Atomic Energy Commission. Samples from this drilling were examined by the author by means of a binocular microscope.

Most of the drill holes bottomed in hard limestone of the Hawthorn Formation, and a thin bed of calcareous clay, residual from the limestone, is present throughout the area (pl. 10). The lower phosphorite unit of the Bone Valley Formation is present throughout the area; individual beds are lenticular and are irregular in distribution. The upper unit of the Bone V.alley is present at all holes except C-3, sec. 8 , at a tributary stream. The surface of the area is covered by quartz sand of Pleistocene age.

\section{HAWTHORN FORMATION}

Limestone or dolomite that is too hard to penetrate by hand auger underlies the entire area of the Waldo-Watson mines. The limestone, as seen in the mining pits, is white, cream, or yellow to buff, sandy and clayey, and contains abundant fine-grained to very fine grained brown, gray, and amber phosphate. An analysis of the limestone from the Watson mine is given in table 11. White, cream, gray, or brown, residual sandy calcareous clay overlies the limestone throughout the area. The clay contains fine quartz sand and fine white, brown, amber, gray, and some black phosphate particles.

The calcareous clay is a part of the calcium phosphate zone, and at most areas in the Watson mine it contains enough phosphate of high enough $\mathrm{P}_{2} \mathrm{O}_{5}$ content to be economic. This is the so-called bedclay matrix. The bedclay is fairly uniform in thickness, ranging from about 1 foot at hole $\mathrm{N}-11$ in sec. 17 to slightly more than 5 feet at hole $\mathrm{G}-3$ in sec. 5 (pl. 10). 
TABLE 11.-Screen and analytical data, lower part of the Hawthorn Formation, SW $1 / 4$ SW $1 / 4$ sec. 9, T. 32 S., R. 25 E., Watson mine

[Screen tests by Thornton \& Co., Tampa, Fla., under contract to the U.S. Geol. Survey. Analysts (U.S. Geol. Survey): F. S. Grimaldi (chemical); J.J. Warr, Jr., and Emma Humphrey (eU-radiometric)]

\begin{tabular}{|c|c|c|c|c|c|c|}
\hline \multirow{2}{*}{ Sample and lab. No. } & \multirow{2}{*}{ Mesh fraction } & \multirow{2}{*}{$\begin{array}{l}\text { Weight } \\
\text { percent }\end{array}$} & \multicolumn{4}{|c|}{ Analyses, in percent } \\
\hline & & & $\mathrm{P}_{2} \mathrm{O}_{5}$ & $\mathbf{F}$ & U & $\mathrm{eU}$ \\
\hline 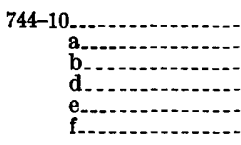 & $\begin{array}{l}\text { Total sample. } \\
+14 \text { (pebble) } \\
-14+35 \text { (feed) } \\
-150 \text { (slime) } \\
-35+150 \text { (concentrate) } \\
-35+150 \text { (tailings) }\end{array}$ & $\begin{array}{r}100.0 \\
13.1 \\
5.5 \\
63.2 \\
8.3 \\
9.9\end{array}$ & $\begin{array}{r}6.5 \\
9.3 \\
20.8 \\
2.2 \\
29.4 \\
3.0\end{array}$ & $\begin{array}{r}0.78 \\
1.06 \\
2.14 \\
.39 \\
2.47 \\
.24\end{array}$ & $\begin{array}{r}0.003 \\
.004 \\
.006 \\
.001 \\
.008 \\
.001\end{array}$ & $\begin{array}{r}0.003 \\
.004 \\
.007 \\
.001 \\
.008 \\
.001\end{array}$ \\
\hline
\end{tabular}

BONE VALLEY FORMATION

The lower unit of the Bone Valley Formation is a gray-green, gray, rust, brown, and tan clayey sand to sandy clay. Three interbedded lenticular lithologic units are shown on plate 10: clayey sand, sandy clay characterized by fine-grained phosphate, and clayey sand characterized by abundant coarse-grained to very coarse grained phosphate. Beds of clay without phosphate are scarce but have been found (hole O-11, sec. 6).

The phosphate nodules in the lower unit of the Bone Valley are white, brown, and gray. Amber phosphate grains are common near the base of the calcium phosphate zone and are more characteristic of the phosphate in the Hawthorn than in the Bone Valley. Black grains are sparse. Although most of the phosphate is fine grained, granulesize phosphate is abundant. The lower unit ranges in thickness from 8 to $291 / 2$ feet and averages about 17 feet.

The upper unit of the Bone Valley Formation, which ranges in thickness from 0 to about 20 feet and averages about $81 / 2$ feet, is a gray, light-gray, or white clayey sand, interbedded with clayey sand containing fragments or thin beds of vesicular-textured, aluminum phosphate-cemented sand. Thin beds of sand (hole $\mathrm{O}-11$, sec. 18) or clay (hole K-10, sec. 17) are sparse. The lithologic units in the upper unit of the Bone Valley are lenticular but traceable for longer distances than are the beds in the lower unit of the formation. Soft, white phosphate is common in the basal part of the upper unit.

\section{TERRACE DEPOSITS}

Loose sand at the surface is of Pleistocene age. Erosion took place after the deposition of the upper unit of the Bone Valley Formation, as indicated in $\log \mathbf{K}$, which shows that boulders of aluminum phosphatecemented sand of the upper unit are incorporated in the sand of Pleistocene age. Figure 4 shows a sand-filled channel that cuts through the Bone Valley at the Watson mine. 
The loose sand ranges in thickness from about 2 feet to more than 16 feet (pl. 10) and probably averages about 6 feet.

Log K.-Mine-face section at the Watson mine, sec. 9, T. 32 S., R. $25 \mathrm{E}$.

Pleistocene:

[Adapted from $\log$ by J. B. Catheart and Louis Pavlides]

Terrace sand :

Thickness (feet)

Sand, loose, fine, carbonaceous

Sand, loose, fine, white. 1/2-ft bed of rubble $1 \mathrm{ft}$ above base.

Boulders consist of aluminum phosphate-cemented sand, and some contain abundant soft, white phosphate grains _-.. 13.0

Total terrace sand

Pliocene :

Bone Valley Formation (upper unit) :

Clay, sandy, white; irregularly mottled with rust-colored limonite stains. Sand fraction is fine

Sand, clayey, light-gray and tan

Sand, clayey, white; soft, white phosphate of granule and coarsesand size

Bone Valley Formation (lower unit) :

Clay, sandy, or very clayey sand; mottled white and rust; contains about 10 percent fine- to medium-sand-size phosphate. Most of the phosphate is tan, but some is white. Small amounts of soft, white phosphate in top $2 \mathrm{ft}$

Sand, clayey, light-gray and tan; abundant ( \pm 35 percent) tan and white phosphate nodules. Bed contains manatee bones

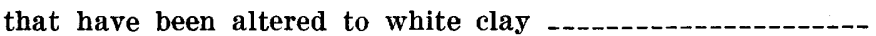

Clay, sandy, greenish-gray ; abundant very fine sand-size tan phosphate and small amounts of white phosphate. This bed is persistent laterally through the pit

Sand, clayey, light-brown and gray; contains about 30 percent fine-sand-size white and amber phosphate. White grains are more abundant than amber

Sand, very slightly clayey, gray; mottled with rust. Contains only enough clay to bind the sand. Quartz-sand fraction is medium to fine. Phosphate grains are amber and white, the amber being dominant, and the phosphate is the same size as the quartz. The grain size increases with depth

Total exposed Bone Valley Formation

Base of the exposure. Limestone or dolomite of the Hawthorn Formation is exposed in the center of the pit, a few feet below the base of the lowest exposure.

\section{ECONOMIC GEOLOGY}

\section{CALCIUM PHOSPHATE ZONE}

The calcium phosphate zone at the Watson mine consists of both the lower unit of the Bone Valley Formation and calcareous clay of the Hawthorn Formation. The zone ranges in thickness from less than 
10 feet along the streams to about 33 feet elsewhere and averages about 20 feet. Most of the zone is in the lower unit of the Bone Valley Formation-the residual Hawthorn clay ranges in thickness from 1 to about 5 feet and averages 3 feet. Although most of the samples were of the total thickness of the zone, a few samples of just the Hawthorn part of the zone indicate that both the $\mathrm{P}_{2} \mathrm{O}_{5}$ and uranium contents of the phosphate nodules in the Hawthorn Formation are lower than in the Bone Valley.

LoG L.-Drill hole in $\$ E 1 / 4 S E 1 / 4$ sec. 6, T. $\$ 2 S .$, R. 25 E.

[Analyses by Swift \& Co. chemists, under contract. See fig. 15 for graphic log and

Pleistocene: gamma-ray log]

Terrace sand:

Thickness (feet)

Sand, loose, gray, medium to fine 9.5

Pliocene :

Bone Valley Formation (upper unit) :

Sand, Clayey, tan-white. Clay is white, kaolinitic.

Some iron stain on quartz grains

Clay, very sandy, white -...-.....-.--

Clay, sandy, white; grains and some granules of soft, white phosphate

(Analyses, in percent, of all the upper unit: $\mathrm{P}_{2} \mathrm{O}_{5}=10.4 ; \mathrm{CaO}=2.0 ; \mathrm{Al}_{2} \mathrm{O}_{3}=$ $12.6 ; \mathrm{U}_{3} \mathrm{O}_{8}=0.016$.)

Bone Valley Formation (lower unit) :

Clay, sandy, gray; abundant white phosphate

Clay, slightly sandy, brown; abundant sand-size grains of hard white phosphate

Clay, very sandy, dark- to light-brown; some brown and white sand-size phosphate

Sand, clayey ; very abundant brown sand-size, and some granulesize, phosphate

Total Bone Valley Formation

Miocene :

Hawthorn Formation (lower part) :

Clay, sandy, calcareous, white and buff ; minor amounts of phosphate

Clay, slightly sandy, calcareous, gray-blue; brown sand-size phosphate

At base of hole a few cuttings of soft, white sandy, clayey limestone were recovered. Material beneath this was too hard to penetrate by hand auger.

The calcium phosphate zone at drill hole $\mathrm{L}$ is mostly in the lower unit of the Bone Valley Formation, but a thin bed of calcareous clay of the Hawthorn Formation is also included in the zone. Somewhat 
more than half of the total uranium is in the pebble and concentrate fractions of the zone, and somewhat less than half is in the slime fraction (fig. 15). About one-third of the total phosphate is in the slime fraction, and all but a very small amount of the rest of the phosphate is in the pebble and concentrate fractions. The slime fraction has been enriched somewhat in uranium.

The gamma-ray log (fig. 15) shows two peaks and two troughs of radioactivity within the calcium phosphate zone; these are due to differences in the clay and phosphate-nodule content of the different beds of the zone. The bedclay matrix is slightly less radioactive than the overlying phosphate, and the radioactivity drops very sharply in the limestone of the Hawthorn Formation.

\section{ALUMINUM PHOSPHATE ZONE}

The aluminum phosphate zone is present in the area of the Watson mine except along Whidden Creek and its tributaries. In a very general way, the zone corresponds to the upper unit of the Bone Valley Formation, except that the zone of soft, white phosphate at holes G-3, sec. 5, and B-10, sec. 4 (pl. 10), is probably the leached upper part of the lower unit of the Bone Valley.

More than 95 percent of the uranium and about 85 percent of the $\mathrm{P}_{2} \mathrm{O}_{5}$ in the aluminum phosphate zone are in the slime fraction (fig. 15). The gamma-ray log shows two peaks of radiation: one is at the base of the aluminum phosphate zone, in the soft, white phosphate, and the other is higher in the section. The radiation decreases sharply at the contact of clayey sand with the overlying loose sand-the upper contact of the aluminum phosphate zone.

Twenty-three drill holes in a 920 -acre area owned by Swift \& Co. were sampled for the aluminum phosphate zone. The samples represent more than 14 million long tons of material having an average content of about 0.010 percent uranium and almost 7 percent $\mathrm{P}_{2} \mathrm{O}_{5}$.

\section{JANE JAY MINE}

The Jane Jay mine is in secs. 21 and 28, T. 32 S., R. 25 E., close to the Peace River, and south of the city of Fort Meade. The area was mined many years ago, the pits are small and open, and the overburden is in piles at the sides of the pits. Mining was by hydraulic methods and only the pebble was recovered.

The Jane Jay mine was operated by the International Phosphate Co. from 1908 (Sellards, 1909, pl. XII) to 1918. In 1920 L. N. Pipkin (Gunter, 1922) operated or leased the Jane Jay mine for the Peninsular Phosphate Co. (Wayne Thomas, written commun., 1959). The Peninsular Phosphate Co. was taken over by the Polk Phosphate Co. 

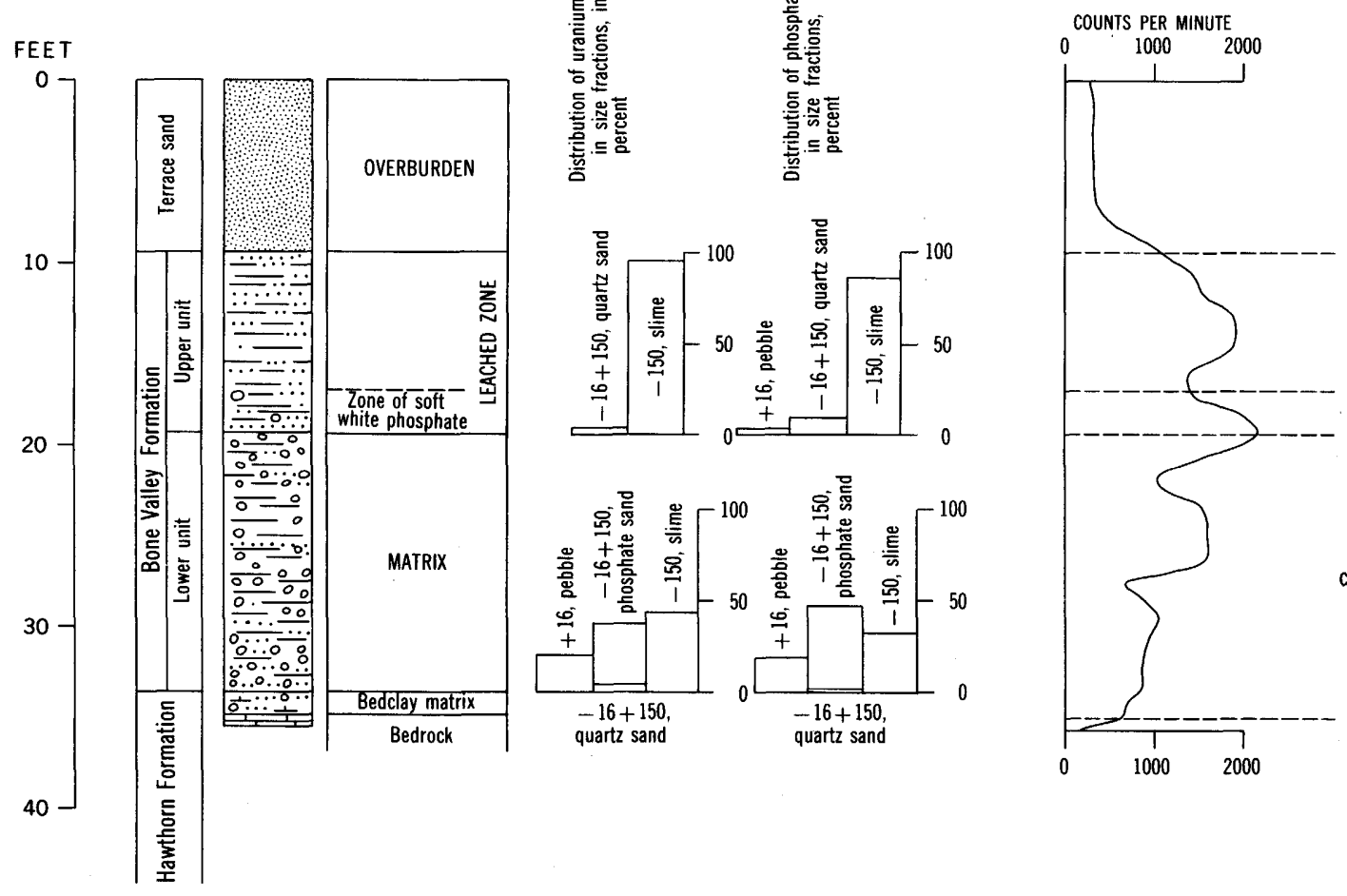

EXPLAṄATION
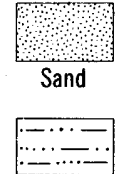

Clayey sand

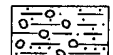

Sandy clay containing phosphate nodules

$$
\begin{array}{rrr}
0 & 0 \\
\hdashline & 0 & 0 \\
\hdashline & 0 & 0 \\
\hdashline & 0 & 0 \\
0
\end{array}
$$

Calcareous sandy clay containing phosphate nodules

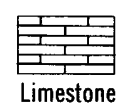


about 1924, and in the 1950's the land of the Polk Phosphate Co. in the area of the Jane Jay mine was acquired by the Tennessee Corp.

\section{STRATIGRAPHY}

Very little data on the stratigraphy of the area are available. All drilling was done many years ago, and the only data available from this drilling are economic. A few hand-auger holes were bored by the Survey in the washer-debris piles at the Jane Jay mine; data from these holes are presented in table 12. In his report, Matson (1915, p. 44) presented a stratigraphic section, the location of which he gave as "in the International Phosphate Co.'s mine, Jane Jay." The section probably was recorded in either the $\mathrm{NE}^{1} / 4 \mathrm{NW}^{1} / 4$ sec. 28 , or the $\mathrm{SE} 1 / 4 \mathrm{SW} 1 / 4$ sec. 21 , both in T. $32 \mathrm{~S}$, R. $25 \mathrm{E}$. The section, as given by Matson, is as follows:

Section in the International Phosphate Co.'s mine, Jane Jay

Overburden :

Loose gray sand containing many pebbles and fragments of phosphatic marl

Sandy, gray phosphatic marl resting upon an uneven surface of phosphate gravel

Phosphate:

Gray sand alternating with layers of coarse and fine phosphate pebbles

Thin, laminated, olive-green clay containing fine phosphate pebbles-"Bedrock" :

Light-yellow limestone and marl with phosphate pebbles

Matson (1915, p. 45) pointed out: "The limestone has an irregular upper surface and was apparently extensively weathered before the deposition of the phosphate. Eroded casts of shells showing considerable abrasion, which were doubtless reworked from the 'bedrock', are numerous in the upper portion of the phosphate deposit."

The limestone bedrock is in the lower part of the Hawthorn Formation, which is known to form the bedrock at the Watson mine just to the north and to crop out along the Peace River. The phosphate deposit is probably the lower unit of the Bone Valley Formation, although the laminated clay may be the upper part of the Hawthorn Formation.

The phosphatic marl, the bottom bed of the overburden according to Matson, is probably the same phosphatic marl described by Sellards $(1910$, p. 34$)$, who pointed out that it has a vesicularlike texture, contains a high percentage of alumina, and that the phosphate is probably combined with alumina or iron. This material is the aluminum phosphate zone and is probably the vesicular-textured type of material that is formed from the highly phosphatic lower unit of the Bone 
Valley Formation. The upper unit of the Bone Valley Formation is probably absent at this locality, which is close to the Peace River where the upper unit has probably been removed by erosion.

The loose gray sand at the surface is probably Pleistocene or Recent and disconformably overlies the phosphatic marl, as indicated by the reworked fragments of phosphatic marl in the loose sand. This is further evidence that there was some erosion in this area prior to the deposition of the Pleistocene materials.

\section{ECONOMYC GEOLOGY}

\section{CaLCIUM phosphate zONE}

The calcium phosphate zone is present throughout the mining area (fig. 16). Only the coarse-pebble fraction was mined; the undersize material from the recovery plant, called washer debris, was piled in three small areas. The debris piles, containing about 800,000 long tons of material, were augered by the Survey in 1949 (table 12). The samples were screened by Thornton \& Co. of Tampa, under contract to the Survey.

TABLE 12.-Soreen and analytical data and distribution of $\mathrm{P}_{2} \mathrm{O}_{5}$ and uranium, washer debris areas, Jane Jay mine, secs. 21 and 28, T. 32 S., R. $25 E$.

[A verages of 10 samples. Analysts (U.S. Geol. Survey): J. J. Rowe and I. H. Barlow $\left(\mathrm{P}_{2} \mathrm{O}_{5}\right)$; Norma Guttag and Isabel Robinson (U)]

\begin{tabular}{|c|c|c|c|c|c|c|c|c|}
\hline Mesh fraction & $\begin{array}{l}\text { Weight } \\
\text { percent }\end{array}$ & $\begin{array}{l}\mathrm{P}_{2} \mathrm{O}_{3} \\
\text { (per- } \\
\text { cent) }\end{array}$ & $\begin{array}{c}\mathrm{U} \\
\text { (per- } \\
\text { cent) }\end{array}$ & $\begin{array}{l}\text { Long } \\
\text { tons }\end{array}$ & $\begin{array}{c}\mathrm{P}_{2} \mathrm{O}_{5} \\
\text { (tons) }\end{array}$ & $\left|\begin{array}{ll}\mathrm{P}_{2} \mathrm{O}_{5} & \text { dis- } \\
\text { tribution } \\
\text { (percent) }\end{array}\right|$ & $\begin{array}{c}\mathrm{U} \\
\text { (tons) }\end{array}$ & $\begin{array}{c}\text { U dis- } \\
\text { tribution } \\
\text { (percent) }\end{array}$ \\
\hline $\begin{array}{l} \pm 14 \text { (pebble) } \\
\begin{array}{l}14+35 \text { (feed) } \\
-35+150 \text { (concentrate) }\end{array} \\
-35+150 \text { (tailings) } \\
-150 \text { (slime) }\end{array}$ & \begin{tabular}{r|}
5.2 \\
29.8 \\
17.2 \\
41.5 \\
6.3
\end{tabular} & $\begin{array}{r}29.9 \\
15.6 \\
32.8 \\
1.7 \\
123.0\end{array}$ & $\begin{array}{r}0.011 \\
.003 \\
.006 \\
.001 \\
1.005\end{array}$ & $\begin{array}{r}42,000 \\
238,000 \\
138,000 \\
332,000 \\
50,000\end{array}$ & $\begin{array}{r}12,600 \\
37,100 \\
45,200 \\
5,600 \\
11,500\end{array}$ & $\begin{array}{r}11.3 \\
33.1 \\
40.3 \\
5.0 \\
10.3\end{array}$ & $\begin{array}{l}4.6 \\
7.1 \\
8.3 \\
3.3 \\
2.5\end{array}$ & $\begin{array}{r}17.8 \\
27.5 \\
32.2 \\
12.8 \\
9.7\end{array}$ \\
\hline Head.- & 100.0 & 14.0 & $.003+$ & 800,000 & 112,000 & & & - \\
\hline
\end{tabular}

1 Calculated, no assay data.

The washer debris is a sand of quartz and phosphate, containing only a small amount of pebble and a trace of slime $(-150$ mesh $)$. The slime fraction probably was removed by natural hydraulic separation.

$\mathrm{P}_{2} \mathrm{O}_{5}$ and uranium are concentrated in the phosphate products-the pebble and concentrate -and only minor amounts are in the slime and in the sand tailings. The debris piles could probably be remined for flotation feed.

The calcium phosphate zone was present at all holes drilled in the mine area (fig. 16), but at the drill holes closest to the Peace River the zone consisted entirely of river pebble. The delineation of river pebble is based on the sharp changes in the pebble/concentrate ratio (from much less than 1 to, usually, $\infty$ ) and on a distinct lowering of 


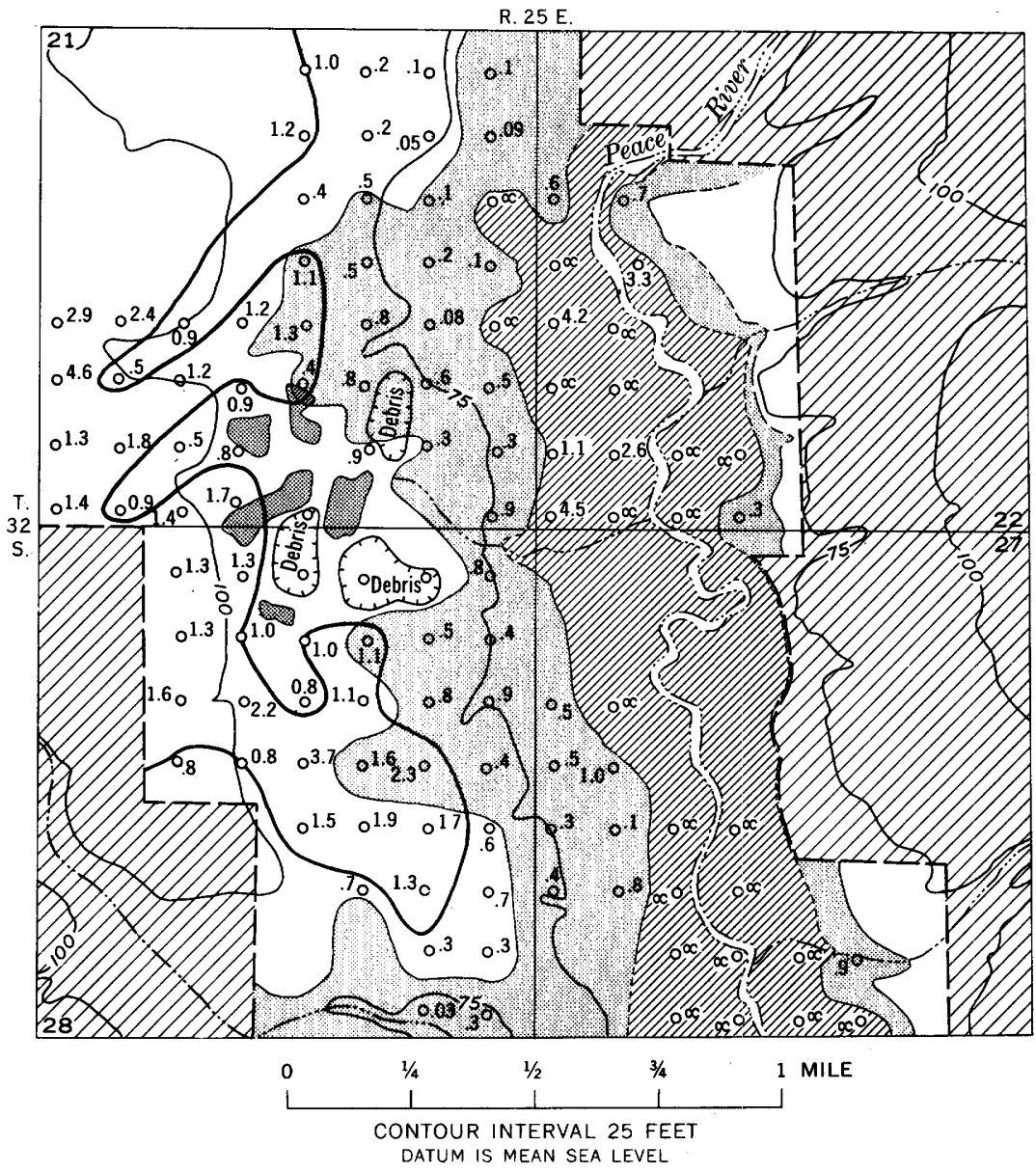

\section{EXPLANATION}

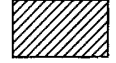

River-pebble phosphate; aluminum phosphate zone absent

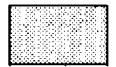

Land-pebble phosphate; aluminum phosphate zone absent

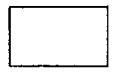

Land-pebble phosphate; aluminum phosphate zone present

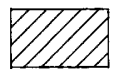

Area of no information

\section{Contact}

Dashed where uncertain

$$
0.3
$$

Drill-hole location Number is ratio of pebble to concentrate. $\propto$ indicates no concentrate

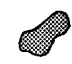

Mined-out area

\section{$E$}

Area underlain by washer debris

Line representing pebble/conglomerate ratio of $1: 1$

West of line, pebble fraction is more abundant; east of line, concentrate is more abundant

FIGURE 16.-Pebble/concentrate ratio and distribution of land- and riverpebble phosphate, Jane Jay mine and surrounding area. 
the amount of $\mathrm{P}_{2} \mathrm{O}_{5}$ in the phosphate products. These changes invariably occur between the same two drill holes.

The land-pebble phosphate in the flatwoods area (between the river pebble and a line about halfway between the 75- and 100-foot contours) is composed mostly of the concentrate fraction, whereas in the areas to the west, above this level, the pebble fraction becomes dominant. The phosphate content of the nodules in the land-pebble rock is above 32 percent $\mathrm{P}_{2} \mathrm{O}_{5}$. In the river-pebble rock the average pebble/concentrate ratio is more than $10: 1$, and at most drill holes the concentrate fraction is not present. The average $\mathrm{P}_{2} \mathrm{O}_{5}$ content of the phosphate nodules is about 29 percent, too low to be economic.

The overburden (Pleistocene sand plus the upper unit of the Bone Valley and the leached lower unit) thins markedly toward the river. Less than 5 feet of sand overlies the river-pebble phosphate. The thickness of overburden in the flatwoods below about 90 -foot elevation is approximately 12 feet, and above 90 feet it is more than 20 feet.

\section{ALUMINUM PHOSPHATE ZONE}

Little is known of the aluminum phosphate zone in this area. It is not present at or close to the river (fig. 16), but it is probably present at the old mine area, as indicated in the lithologic log by Matson (1915). The gamma-ray logs indicate that the zone has a maximum thickness of about 15 feet. One sample of the zone taken from the old mine dumps contained about 0.010 percent uranium; this indicates that some fairly high grade aluminum phosphate-zone material is present. No data are available on the phosphate content of the zone, but on the basis of the $\mathrm{P}_{2} \mathrm{O}_{5}$ distribution at the Watson mine to the north (fig. 10), there probably are areas that are underlain by aluminum phosphate zone material containing more than 5 percent $\mathrm{P}_{2} \mathrm{O}_{5}$.

\section{IITTLE CHARLIE TRACT}

The Little Charlie tract is in sec. 23, T. 33 S., R. 25 E., Hardee County, on the divide between the Peace River and Little Charlie Creek. Drill holes by the Tennessee Valley Authority were logged by Survey geologists: Louis Pavlides, R. G. Petersen, and the author. Head samples were analyzed for $\mathrm{P}_{2} \mathrm{O}_{5}$ by the Tennessee Valley Authority and for uranium by the Survey. The tract has not been mined.

\section{STRATIGRAPHY}

All geologic information is from drill holes; the surface is covered by quartz sand of Pleistocene age. All drill holes penetrated the Bone Valley Formation and bottomed on hard material, probably limestone or dolomite of the Hawthorn Formation. 
The composite $\log$ which follows shows the typical lithologic sequence and the stratigraphic interpretation based on the lithology.

Composite log, Little Charlie tract, sec. 23, T. 33 S., R. 25 E.

Pleistocene :

Terrace sand :

Thickness (feet)

Sand, loose, gray to black, carbonaceous_______._. 0.5

Sand, loose, white, fine

Sand, loose ; light brown at top to dark brown at base; medium to fine

Sand, dark-brown, iron-cemented, hardpan. Present only under the surface ridge (fig. 17)

Sand, loose, light-brown, medium-grained. At some drill holes a white sand at base

Total terrace sand

15. 0

Pliocene :

Bone Valley Formation (upper unit) :

Sand, clayey, gray or brownish-gray, medium to fine; trace amounts of black phosphate at base at a few drill holes

Bone Valley Formation (lower unit) :

Sand, clayey, gray (some brownish-gray); contains abundant (avg 15 percent) coarse to very coarse, black, some brown, and a few tan phosphate nodules

Total Bone Valley Formation.

Miocene :

Hawthorn Formation (lower part) :

Clay, slightly sandy, calcareous, yellow-brown, cream, and very light gray. Contains traces to about 5 percent fine to very fine phosphate grains

Part of Hawthorn Formation.

Bottomed on hard material (limestone of the Hawthorn).

\section{HAWTHORN FORMATION}

The Hawthorn Formation consists of yellow-brown, cream, lightgray, or white, calcareous, sandy clay overlying hard limestone or dolomite. As much as one-half foot of soft, white sandy limestone was cored at a few drill holes. The soft limestone and the calcareous clay contain rounded and polished fine to very fine phosphate nodules. Phosphate nodules range in volume from a trace to about 5 percent and at most drill holes are between 3 and 5 percent. The nodules are mostly brown, but some are black, a few are tan, and there are traces of white. The residual clay ranges in thickness from 0 to 5.5 feet and averages 2.5 feet. 
The contrast between the present surface and the surface of the Hawthorn Formation is indicated by the ridge crests and the valley bottoms (fig. 17). The stream patterns are broadly similar but differ in detail. The ridge crests are also broadly similar-the principal difference is due to the Hawthorn streams, which have cut farther east than present streams, broken through the ridge, and created a small westward-trending interstream divide in the northeastern part of the section. This divide on the Hawthorn surface is normal to the surface ridge.

\section{BONE VALIEY FORMATION}

The lower unit of the Bone Valley Formation is a gray, blue-gray, or brown-gray sand or clayey sand containing a few beds of clay or sandy clay. All the lithologic types contain medium to very coarse black, brown, and some tan phosphate nodules. Soft, white nodules are present at the top of the unit at one drill hole. Phosphate nodules make up from 5 to 35 percent, by volume, of the unit and average about 15 percent. The unit ranges in thickness from one-half to 10 feet and averages 4 feet.

The upper unit of the Bone Valley Formation is gray or brown clayey sand containing phosphate nodules at a few of the drill holes near the base of the unit. The unit ranges in thickness from 3.5 to 25 feet and averages 14 feet.

The Bone Valley Formation is thickest over the paleostream courses and thinnest over the basement ridges (fig. 17). The relation, although imperfect, is very striking.

The Bone Valley-Hawthorn contact is at the lithologic break between the dark-colored sand or clayey sand containing abundant coarse phosphate, assigned to the Bone Valley, and the underlying lightcolored clay or sandy clay, usually calcareous and containing minor amounts of fine to very fine phosphate grains, assigned to the Hawthorn.

\section{TERRACE DEPOSITS}

Quartz sand of Pleistocene age blankets the surface at the Little Charlie tract (fig. 17). The sand is thickest under the ridge area, in the eastern half of the section, and thins to the west, toward the Peace River. The loose sand ranges in thickness from 7 to 20 feet and throughout the tract consists of a thin surficial layer of gray or black carbonaceous sand underlain by 2-3 feet of fine white leached sand. Brown, iron-stained sand underlies the white sand and grades downward in the ridge area to iron-cemented sand or hardpan. 


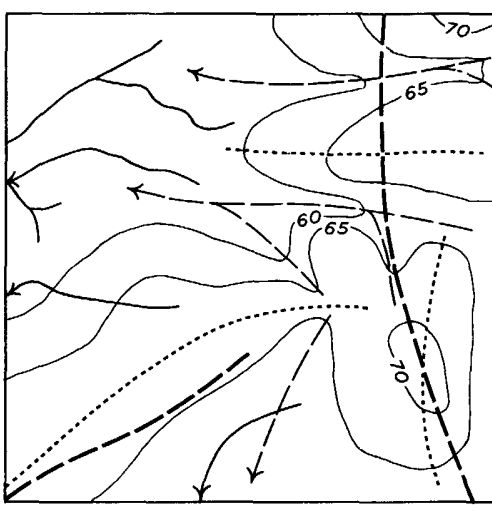

A. HAWTHORN FORMATION

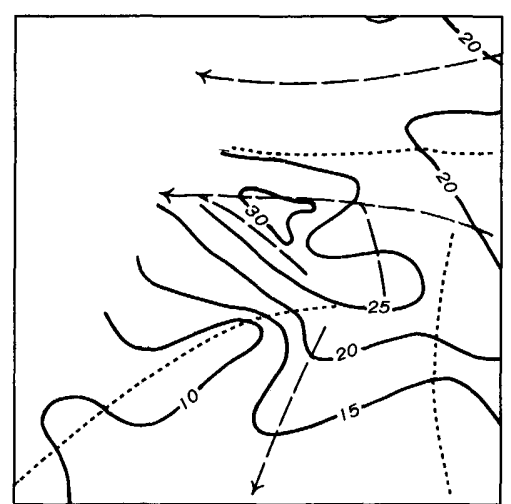

B. BONE VALLEY FORMATION

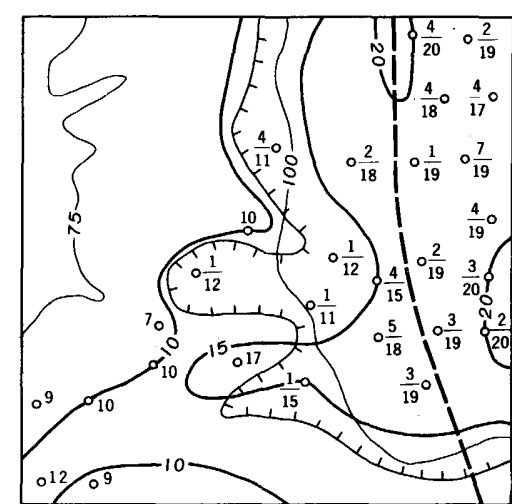

C. LOOSE SAND AND HARDPAN $\frac{1+1+1+1+1+1+1 / 2}{\text { Limits of hardpan }}$ Hachures point to area by hardpan

$$
\text { L }
$$$$
1 / 4
$$

\section{EXPLANATION}

$$
\begin{aligned}
& \text { rest of ridge on the surface Course of modern stream } \\
& \text { rest of ridge } \\
& \circ \frac{4}{20} \\
& \text { Drill-hole location } \\
& \text { Top figure indicates thickness of Contour interval } 5 \text { feet } \\
& \text { hardpan, bottom figure is thickness } \\
& \text { of loose sand, in feet. Single } \\
& \text { in feet, hardpan absent }
\end{aligned}
$$

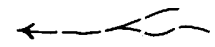

Course of stream on the surface of Hawthorn Formation

$$
\begin{aligned}
& \text { Topographic contour } \\
& \text { Interval } 5 \text { and } 25 \text { feet; }
\end{aligned}
$$$$
\text { datum is mean sea level }
$$

Figure 17.-Hawthorn and Bone Valley Formations, loose sand and hardpan, Little Charlie tract, sec. 23, T. $33 \mathrm{~S}$., R. 25 E. $\quad A$, Subsurface contour map of top of formation, $B, C$, Isopach maps. 


\section{ECONOMIC GEOLOGY}

\section{CALCIUM PHOSPHATE ZONE}

At most of the drill holes in the tract the calcium phosphate zone consists of rocks of both the Hawthorn and the Bone Valley Formations, but most of the zone is in the Bone Valley. Analytical and screen data on the pebble and concentrate fractions are not available; only the raw samples were analyzed.

The uranium content of the samples of the Bone Valley is directly related to the $\mathrm{P}_{2} \mathrm{O}_{5}$ content; samples high in one are also high in the other. The samples of the Hawthorn Formation, however, show no correlation between uranium and $\mathrm{P}_{2} \mathrm{O}_{5}$ content (fig 18).

The economic part of the calcium phosphate zone, the matrix, cannot be determined with certainty. The available data indicate that the part of the calcium phosphate zone assigned to the Bone Valley is more likely to be matrix than the part assigned to the Hawthorn. The recoverable phosphate in the Hawthorn (3-5 percent at most drill holes) is well below the economic limit (about 15 percent).

\section{ALUMINUM PHOSPHATE ZONE}

The aluminum phosphate zone is probably present at most drill holes, although analytical data and gamma-ray logs are completely lacking. Soft, white phosphate was present at the top of the lower unit at one drill hole; hence, the entire upper unit of the Bone Valley Formation was leached at this drill hole. The base of the upper unit was sampled and analyzed at five drill holes. Samples were taken of the unit in those cores where fresh black phosphate was visible. The samples contained 1.0-2.5 percent $\mathrm{P}_{2} \mathrm{O}_{5}$ and 0.001-0.005 percent uranium. They probably represent the unleached part of the upper unit.

The leaching which formed the aluminum phosphate zone extended, in most places, only part way down into the upper unit of the Bone Valley Formation, but it did extend into the upper part of the lower unit at one drill hole. The upper leached part of the upper unit was not sampled, but the very low phosphate and uranium contents of the unleached part of the unit suggest that the aluminum phosphate zone is uneconomic in this tract.

\section{VANDOLAF TRACT}

The Vandolah tract is in secs. 14-16, 19-23, T. 34 S., R. 23 E., in Hardee County at the south edge of the Fort Meade quadrangle. Drilling for the American Metal Climax Co. was done in 1954 by O. H. Wright, who also did the analytical work. The tract has not been mined, and the area is covered by a blanket of loose quartz sand; all geologic data are from drill holes. 


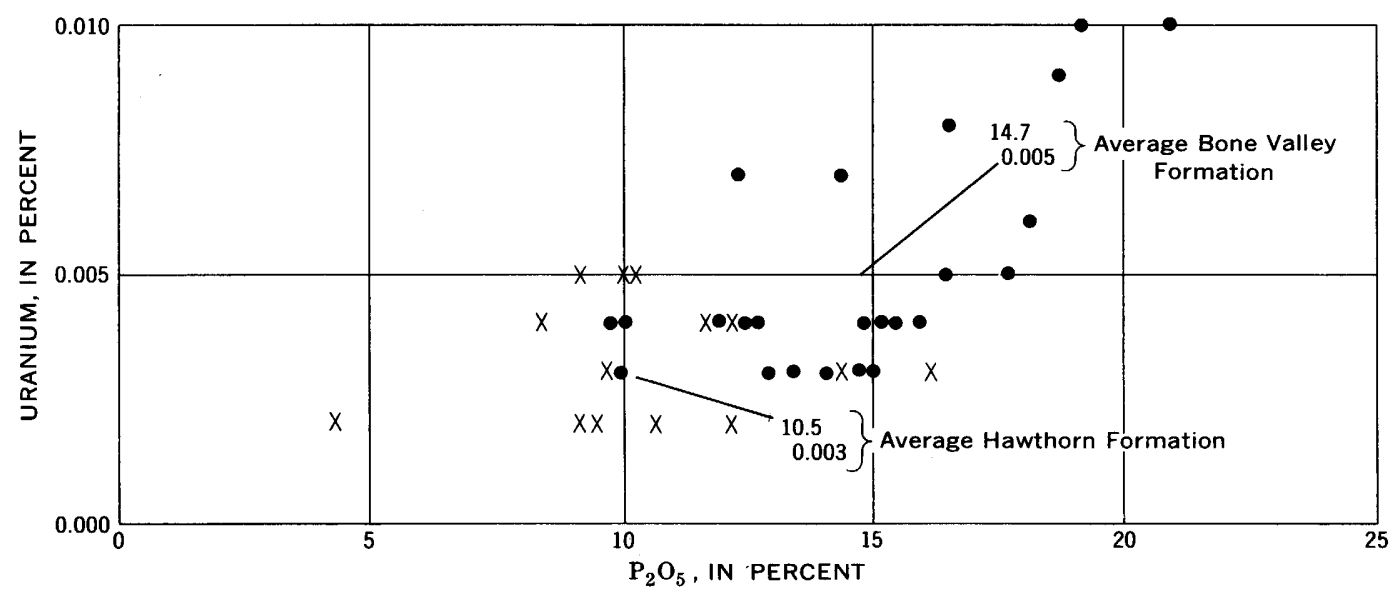

\section{EXPLANATION}

$X$

Sample of the Hawthorn

Formation

Sample of the Bone

Valley Formation

Frgure 18.-Scatter diagram showing $\mathrm{P}_{2} \mathrm{O}_{5}$, uranium relations in raw samples of the calcium phosphate zone, Little Charlie tract, T. 22 S., R. 25 E. $\mathrm{P}_{2} \mathrm{O}_{3}$ analyses by the Tennessee Valley Authority. Uranium analysts (U.S. Geol. Survey) : Marie Eiland, H. B. Kessler, R. B. Randolph, A. J. Robinson, J. J. Rowe, L. Steele, and D. Venesky. 


\section{STRATIGRAPHY}

All drill holes bottomed on hard limestone or on calcareous clays residual from limestone of the lower part of the Hawthorn Formation. Gray sand or clayey to slightly clayey sand containing abundant phosphate nodules - the lower phosphorite unit of the Bone Valley Formation-overlies the Hawthorn Formation. The upper unit of the Bone Valley grades into the underlying lower unit and is in turn overlain by sand of Pleistocene age. No drill holes penetrated deeper than the Hawthorn.

The stratigraphy, as determined from the lithology, is shown in the following composite stratigraphic section.

Pleistocene:

\section{Composite stratigraphic seotion, Vandolah tract}

Terrace sand :

Thickness (ft)

Sand, loose, gray

3. 0

Sand, loose, brown

Total terrace sand

7. 0

Pliocene:

Bone Valley Formation (upper unit) :

Sand, clayey to slightly clayey, light-gray. Trace of phosphate at some localities 12.5

Bone Valley Formation (lower unit) :

Sand, clayey, or loose, gray ; contains black and brown phosphate nodules, granule size more abundant than sand size. Top 1-2 ft may contain soft, white phosphate nodules

Total Bone Valley Formation

27.5

Miocene :

Hawthorn Formation (lower part) :

Clay, gray, white, or yellow, sandy, calcareous. Contains brown, black, and white phosphate nodules. Sand size more abundant than granule size. At some localities the phosphate content is very low

Part of Hawthorn Formation

Bottom in rock too hard to penetrate by hand auger (probably limestone of the Hawthorn Formation).

\section{HAWTHORN FORMATION}

Most of the drill holes bottomed on material too hard to penetrate by hand auger-probably limestone of the Hawthorn Formation. At three of the drill holes, white sandy, very calcareous clay or soft limestone was cored; this material represents the first stage in the formation of the calcareous clay residuum. The Hawthorn at most drill holes 
consists of light-gray, yellow-brown, or blue-gray sandy, calcareous clay. Normally only one of these color varieties occurs at a single drill hole, and they are about equally divided as to the number of holes at which they occur. The clays are $0-23$ feet thick and average about 10.5 feet. Fine phosphate nodules, dominantly brown but also some black and a few polished white, occur in the clays.

The contact of the Hawthorn with the overlying phosphorite of the Bone Valley Formation is nonconformable, and at many drill holes the contact is difficult to locate, particularly where the Hawthorn is a gray sandy clay and the overlying Bone Valley is a gray clayey sand.

The differences in the pebble/concentrate ratio in the two formations and the grade of the phosphate particles are helpful in selecting the contact. For example, at hole 1 (pl. 1) the Bone Valley is a gray clayey sand which contains coarse black phosphate and rests on white calcareous clay. The pebble fraction is more abundant and is higher in $\mathrm{P}_{2} \mathrm{O}_{5}$ content in the Bone Valley than in the Hawthorn.

\section{BONE VALLEY FORMATION}

The Bone Valley Formation consists of two units: the lower phosphorite and the upper clayey sand. Both units are present at every drill hole and are easily distinguished because the upper unit contains little or no visible phosphate. At a few drill holes the lower unit contains so few phosphate nodules that it is not economic, and at these holes the upper and lower units are separated arbitrarily.

The lower unit is a sand, clayey sand, or sandy clay containing abundant black and brown phosphate nodules. Black phosphate is somewhat more abundant than brown. At about 10 percent of the drill holes the upper 2-3 feet of the lower unit contains soft, white leached phosphate nodules. White phosphate nodules are not present elsewhere in the lower unit, whereas in the Hawthorn Formation they are present at a few drill holes.

The lower unit is uniformly gray at all but a few drill holes, where it is blue or blue gray. The unit is sandier than the underlying Hawthorn Formation and tends to be a sand or clayey sand rather than a sandy clay. Clay beds are not present in the lower unit of the Bone Valley Formation. The phosphate nodules are both granule and sand size but tend to be coarse; the pebble/concentrate ratio is almost everywhere more than 1.0. The lower unit ranges in thickness from 3 to 36.5 feet and averages about 15 feet.

The upper unit of the Bone Valley Formation at about 90 percent of the holes drilled is a light-gray clayey sand. Some sandy clay and clay is present. Sandrock-sand cemented by aluminum phosphate minerals-is present at only two of the drill holes. The upper unit 
is leached, so the lack of sandrock indicates that there was very little phosphate present before leaching.

The upper unit ranges in thickness from 0 to 32 feet and averages about 12.5 feet.

\section{TERRACE DEPOSITS}

Loose quartz sand at the surface is Pleistocene in age. The sand blankets the area and ranges in thickness from 2 to 20 feet and averages about 7 feet. At most drill holes the surficial sand is gray and is underlain by brown, iron-stained sand. Hardpan is present at only four of the holes drilled in the tract; the brown sand is an incipient hardpan.

Swamp muck, a black organic clayey sand of Recent age, was present at only one drill hole in the tract, and white windblown sand is present at only a few drill holes.

\section{ECONOMIC GEOLOGY}

The aluminum phosphate and calcium phosphate zones are present at all drill holes, but the economic or possibly economic parts of these zones may not be present at all localities (section $D-D^{\prime}$, pl. 1).

\section{CaLCIUM PhOSPHATE ZONE}

Although the calcium phosphate zone is usually composed of rocks of both the Bone Valley and Hawthorn Formations, the economic part of the zone includes only the lower unit of the Bone Valley. The relations shown on section $D-D^{\prime}$ (pl. 1) are characteristic of the tract. At hole 1 the possibly economic calcium phosphate zone is the middle part of the lower phosphorite unit. The top part is leached; phosphate nodules in the basal part are too low grade to be economic. At holes 2-5 the economic part of the calcium phosphate zone is in the lower phosphorite unit and includes the entire unit, except at hole 2 , where the upper 4 feet is leached. At holes 3-5 the calcium phosphate zone includes residuum from the Hawthorn, but the residuum contains small amounts of phosphate nodules, low in $\mathrm{P}_{2} \mathrm{O}_{5}$ content, and it is not economic. At hole 6 the calcium phosphate zone is thick and entirely in the Bone Valley, but phosphate nodules in this material are too low in $\mathrm{P}_{2} \mathrm{O}_{5}$ content and too sparse to be economic. At many of the drill holes the residual clay of the Hawthorn Formation contains economic amounts of phosphate, but generally the phosphate particles contain less $\mathrm{P}_{2} \mathrm{O}_{5}$ than the phosphate particles in the lower unit of the Bone Valley Formation (table 13), and although the total tonnage in the two formations is about the same, the Bone Valley contains a much higher pebble/concentrate ratio than does the Hawthorn. 
TABLE 13.-Comparison of phosphate in the Bone Valley and Hawthorn Formations, Vandolah tract

[Analyses by American Metal Climax Co., used by permission]

\begin{tabular}{|c|c|c|c|c|c|c|}
\hline & \multirow{2}{*}{$\begin{array}{l}\text { Number } \\
\text { of } \\
\text { samples }\end{array}$} & \multicolumn{2}{|c|}{$\mathrm{P}_{2} \mathrm{O}_{5}$ content } & \multicolumn{2}{|c|}{ Tons per acre-foot } & \multirow{2}{*}{$\begin{array}{l}\text { Pebble/con- } \\
\text { centrate ratio }\end{array}$} \\
\hline & & Range & Average & Range & A verage & \\
\hline $\begin{array}{l}\text { Bone Valley Formation: } \\
\text { Pebble } \\
\text { Concentrate. }\end{array}$ & $\begin{array}{r}106 \\
51\end{array}$ & $\begin{array}{l}18.0-32.5 \\
29.6-33.3\end{array}$ & $\begin{array}{l}29.3 \\
31.6\end{array}$ & $\begin{array}{r}30-460 \\
0-350\end{array}$ & $\begin{array}{r}200 \\
90\end{array}$ & 2.23 \\
\hline $\begin{array}{l}\text { Hawthorn Formation: } \\
\text { Pebble } \\
\text { Concentrate. }\end{array}$ & $\begin{array}{l}53 \\
20\end{array}$ & $\begin{array}{r}5.1-27.8 \\
24.1-31.8\end{array}$ & 22.2 & $\begin{array}{r}10-300 \\
150-500\end{array}$ & $\begin{array}{r}70 \\
210\end{array}$ & 0.33 \\
\hline
\end{tabular}

The calcium phosphate zone is $0-30$ feet thick and averages 15 feet.

\section{ALUMINUM PHOSPHATE ZONE}

The aluminum phosphate zone includes the leached upper unit of the Bone Valley Formation and, at places, the leached top part of the lower unit. The part of the zone that may be economic is determined by the high radiation peak on the gamma-ray logs (section $D-D ; \mathrm{pl}$. 1). All the gamma-ray logs are similar; they show very little radiation in the overburden sands, somewhat more activity in the top of the clayey sands, and a high peak within the clayey sand, or at the base of the clayey sand and in the top of the phosphorite.

The $\mathrm{P}_{2} \mathrm{O}_{5}$ content of the zone is not known, but the equivalent uranium content as shown by the gamma-ray logs averages about 0.010 percent, and the phosphate content is probably about 5-6 percent $\mathrm{P}_{2} \mathrm{O}_{5}$ over much of the area.

The aluminum phosphate zone ranges in thickness from 0 to about 17 feet and averages about 7 feet.

\section{REFERENCES CITED}

Altschuler, Z. S., Cisney, E. A., and Barlow, I. H., 1952, X-ray evidence of the nature of carbonate-apatite [abs.] : Geol. Soc. America Bull., v. 63, no. 12, pt. 2, p. 1230-1231.

Altschuler, Z. S., Clarke, R. S., Jr., and Young, E. J., 1958, Geochemistry of uranium in apatite and phosphorite: U.S. Geol. Survey Prof. Paper 314-D, p. $45-90$.

Altschuler, Z. S., Jaffe, E. B., and Cuttita, Frank, 1956, The aluminum phosphate zone of the Bone Valley Formation, Florida, and its uranium deposits [Florida], in Page, L. R., Stocking, H. E., and Smith, H. B., compilers, Contributions to the geology of uranium and thorium by the United States Geological Survey and Atomic Energy Commission for the United Nations International Conference on Peaceful Uses of Atomic Energy, Geneva, Switzerland, 1955: U.S. Geol. Survey Prof. Paper 300, p. 495-504.

Applin, P. L., and Applin, E. R., 1944, Regional subsurface stratigraphy and structure of Florida and southern Georgia: Am. Assoc. Petroleum Geologists Bull., v. 28, no. 12 , p. $1673-1753$. 
Bergendahl, M. H., 1956, Stratigraphy of parts of De Soto and Hardee Counties, Florida : U. S. Geol. Survey Bull. 1030-B, p. 65-98.

Berman, Robert, 1953, A mineralogic study of churn drill cuttings from a well through the Bone Valley Formation, Hillsborough County, Florida [abs.]: Nuclear Sci. Abs., v. 7, no. 18A, abs. 5060, p. 616.

Brodkorb, Pierce, 1955, The avifauna of the Bone Valley Formation: Florida Geol. Survey Rept. Inv. 14, 57 p.

Cathcart, J. B., 1956, Distribution and occurrence of uranium in the calcium phosphate zone of the land-pebble phosphate district of Florida, in Page, L. R., Stocking, H. E., and Smith, H. B., compilers, Contributions to the geology of uranium and thorium by the United States Geological Survey and Atomic Energy Commission for the United Nations International Conference on Peaceful Uses of Atomic Energy, Geneva, Switzerland, 1955: U.S. Geol. Survey Prof. Paper 300, p. 489-494.

1963a, Economic geology of the Keysville quadrangle, Florida: U.S. Geol. Survey Bull. 1128, 82 p.

1963b, Economic geology of the Plant City quadrangle, Florida : U.S. Geol. Survey Bull. 1142-D, p. D1-D56.

-1963c, Economic geology of the Chicora quadrangle, Florida: U.S. Geol. Survey Bull. 1162-A, p. A1-A66.

1964, Economic geology of the Lakeland quadrangle, Florida: U.S. Geol. Survey Bull. 1162-G, p. G1-G128.

Cathcart, J. B., and Davidson, D. F., 1952, Distribution and origin of phosphate in the land-pebble district of Florida: U.S. Geol. Survey TEI-212, issued by U.S. Atomic Energy Comm. Tech. Inf. Service, Oak Ridge, Tenn., 12 p.

Cathcart, J. B., and McGreevy, L. J., 1959, Results of geologic exploration by core-drilling, 1953, land-pebble phosphate district, Florida: U.S. Geol. Șurvey Bull. 1046-K, p. 221-298.

Cooke, C. W., 1945, Geology of Florida : Florida Geol. Survey Bull. 29, 339 p.

Davidson, D. F., 1952, Relation of the "topography" of the Hawthorn Formation to size of phosphate particles in the deposits, and to topography, in the northern part of the land-pebble phosphate field, Florida : U.S. Geol. Survey TEI337, issued by U.S. Atomic Energy Comm. Tech. Inf. Service, Oak Ridge, Tenn., $17 \mathrm{p}$.

Eldridge, G. H., 1893, A preliminary sketch of the phosphates of Florida: Am. Inst. Mining Metall. Engineers Trans., v. 21, p. 196-231.

Fowler, E. D., and others, 1927, Soil Survey of Polk County, Florida : U.S. Dept. Agriculture, Soil Survey Rept. 39, 39 p.

Gunter, Herman, 1922, Statistics on mineral production in Florida during 1920: Florida Geol. Survey 14th Ann. Rept., p. 26-32.

Hunt, C. B., and Hunt, A. P., 1957 Stratigraphy and archeology of some Florida soils: Geol. Soc. America Bull., v. 68, no. 7, p. 797-806.

MacNeil, F. S., 1947, Correlation chart for the outcropping Tertiary formations of the eastern Gulf Coastal Plain : U.S. Geol. Survey Oil and Gas Inv. Prelim. Chart 29.

1950, Pleistocene shorelines in Florida and Georgia: U.S. Geol. Survey Prof. Paper 221-F, p. 95-107.

Matson, G. C., 1915, The phosphate deposits of Florida: U.S. Geol. Survey Bull. 604, $101 \mathrm{p}$.

Matson, G. C., and Clapp, F. G., 1909, A preliminary report on the geology of Florida with special reference to the stratigraphy : Florida Geol. Survey 2d Ann. Rept., p. 25-173. 
Mossom, D. S., 1925, A preliminary report on the limestones and marls of Florida : Florida Geol. Survey 16th Ann. Rept., p. 27-203.

Puri, H. S., 1953, Zonation of the Ocala group in peninsular Florida [abs.] : Jour. Sed. Petrology, v. 23, no. 2, p. 130.

Sellards, E. H., 1909, Mineral industries. Phosphate: Florida Geol. Survey 2d Ann. Rept., p. 235-242.

1910, A preliminary paper on the Florida phosphate deposits: Florida Geol. Survey 3d Ann. Rept., p. 17-42.

1913, Production of phosphate rock in Florida during 1912 : Florida Geol. Survey 5th Ann. Rept., p. 291-294.

1915, The pebble phosphates of Florida: Florida Geol. Survey 7th Ann. Rept., p. 25-116.

Siems, H. B., 1951, Fertilizers, in Kirk, R. E., and Othmer, D. F., eds., Encyclopedia of chemical technology : New York, The Interscience Encyclopedia, Inc., v. 6, p. 376-452.

Vernon, R. O., 1951, Geology of Citrus and Levy Counties, Florida : Florida Geol. Survey Bull. 33, 256 p. 



\section{INDEX}

[Italic page numbers indicate major references]

A Page

Acid-insoluble content.

Acknowledgments.

Altschuler, Z. S., analyst.

Aluminum phosphate zone, analyses...... 43, 44, 64

Consolidated tract . . .

definition. . ................... VI

distribution and thickness.................. 43

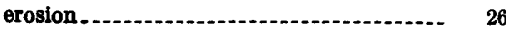

general features............................. 42

Jane Jay mine_............................ 82

Little Charlie tract.....................- 86

South Pierce mine._._................ 55

Tilghman tract............................ 69

tonnage calculations.

uranium content.

Vandolah tract.

Waldo-Watson mines

Amalgamated Phosphate Co

American Agricultural Chemical Co...... 27,

American Cyanamid Co . . ................ 27,

American Metal Climax Co. . ..................

Analysts.

Apatite.

A vifauna

Bedclay, definition

\section{B}

Bedrock, definition.

Bison.

Bone Valley Formation, age.

slteration.

analyses..................

calcium phosphate zone.

characteristics.

Consolidated tract. . .

contact with Hawthorn.

deposition.

distribution and thickness...................

Little Charlie tract.

$\log$

mineral composition............................

sections

$62,66,60,63,66,75,83$

Bouth Pierce mine

stratigraphy

Tilghman tract

Vandolah tract.

Waldo-Watson mines.

Boudreau, C. E., analyst.

Bowling Green.

BPL.

Brewster mine
C

Page

Calcium phosphate zone, analyses......... 31, 33, 34

Consolidated tract. ...................... 61

definition...... VI

distribution and thickness.................. 29

economic factors............................ 29

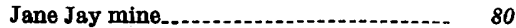

Little Charlie tract._..................... 86

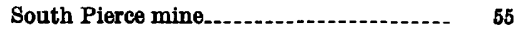

stratigraphy............... 28

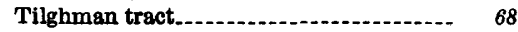

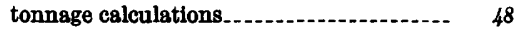

uranium distribution..................... $\$ 5,70$

Vandolah tract........................... 90

Waldo-Watson mines................... 75

Chicora quadrangle................ 21

Climate. ............ 5

Concentrate, definition....................... VI

Consolidated tract, aluminum phosphate zone.... 42

economic geology. 61

Hawthorn-Bone Valley contact............ 13, 59

stratigraphy

Crandallite.............. 23, 39,48

Cuttita, F., analyst. ........................ 22

\section{D}

Drainage.................... 2, 5

Driftrock, definition........................ VI

Drill-hole logs........ 22, 53, 54, 57, 62, 63, 66, 71, 76, 78

$\mathbf{E}$

East Gulf Coastal Plain

Economic geology

Eocene Series . . .

Equus_..._.

Erosion.........

\section{I}

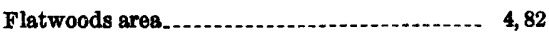

Fluorine, distribution.................... 37

Fossils.................. 7, 12,16,16

G

Gamma-ray logs. .......................... 77,82

Geologic map, preparation.................... 6

Glossary - .......... VI

Grimaldi, F. S., analyst_............. 22

Gulf Coastal Plain. 6 


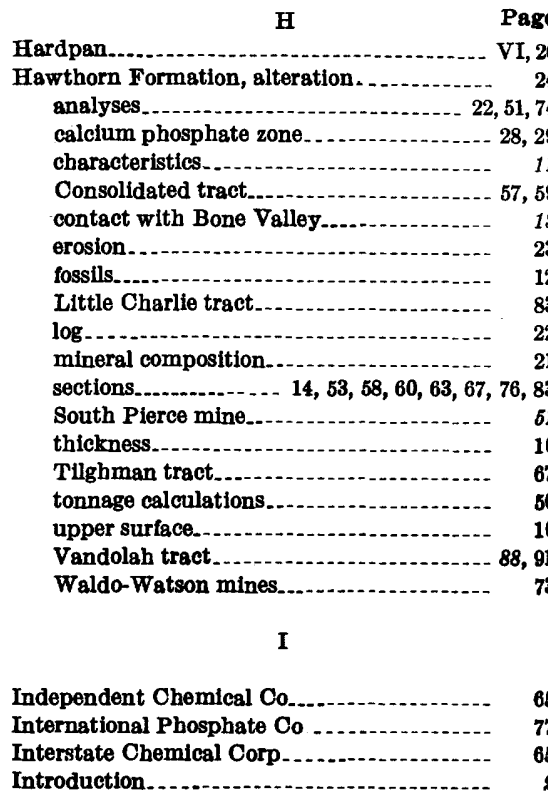

$\mathbf{J}$

Jane Jay mine. $27,77,79,80$

\section{$\mathbf{K}$}

Karst. See Topography.

Keystille quadrangle

\section{I}

Land-pebble deposits.

Land-pebble phosphate district.

Lateritic weathering.

Leaching.

Leon soll



Little Charlie tract. .................... $88,84,86$

Little Payne Creek...................... 10, 65

Logs. See Drill-hole logs; Well logs.

\section{$\mathbf{M}$}

Mastodon

Matrix, definition

Matson, G. C., stratigraphic sections.

Mineral composition.

Mines.

Mining, history

Mlocene Series.

\section{$\mathbf{N}$}

Nonnippus minor.

Neohipparion phosphorum

Nodule, definition.

Ocala Limestone

Ocala uplift

Okefenokee shoreline

Oligocene Series.

Olive Branch

Overburden
$\mathrm{P}_{2} \mathrm{O}_{6}$ distribution.

$\mathbf{P}$

Page

Palmetto mine

Payne Creek . . .............. 10

Peace River............ 10,20

Pebble, definition. ....................... VI

Pebble/concentrate ratios................... 33

Peninsular Phosphate Co.................... 77

3 Phosphate nodules, size variations........... \$1

12 Physiographic divisions..................... 2

23 Plant City quadrangle..................... 21

2 Pleistocene Series............................... 18

Pleistocene shorelines....................... 4,20

Pleistocene soll profile . ...................... 26

Pliocene Series . . . . .

Polk Phosphate Co....... 77

Prosthenop8_........... 16

Punta Gorda........ 27

Recent deposits. . . . . .

References cited......... 91

Regional geology ........................ 6

Reserves. See Tonnage calculations.

Rldge area......... 2

River-pebble deposits. . . . . . 20, 27

$\mathbf{S}$

Sandrock, definition....................... VI

Screen size, definition.................... VI

Screen tests............. 51, 74, 80

Shorelines. See Pleistocene shorelines.

Slime, definition........................... VI

Soil profile............. 26

South Pierce mine....................... 16, 50,56

Stratigraphy. . . .

Streams . .

Structure.............. 21

Suwannee Limestone........................ 9

Swift \& Co...... 28, 72

\section{$\mathbf{T}$}

Tailings, definition......................... VI

Tampa Limestone........ 9

Teloceras proterus............ 16

Tennessee Corp . . .

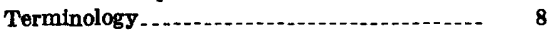

See also Glossary.

Terrace deposits, Consolidated tract.......... $\quad 60$

general features............................. 18

Little Charlie tract.................... 84

section

South Pierce mine.................... 65

Tilghman tract..................... 68

Vandolah tract.................. 90

Waldo-Watson mines............... 74

Tilghman Phosphate Co

Tilghman tract........... 65

Tonnage calculations, aluminum phosphate zone.

calcium phosphate zone................ 48

Hawthorn Formation. . ...... 50

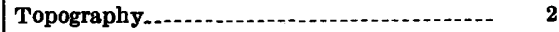

Tracts_. 
Page

Vandolah tract..................... 26, 86, 88, 90

Vertebrate fossils. See Fossils.

Weathering .... .

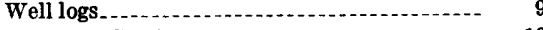

$\mathbf{W}$

Whidden Creek.

Wicomico shoreline.......................... 20

Waldo-Watson mines.

$13,19,21,28,42,72,75$

Z

Wavellite.

23, 39, 48 Zolfo Springs.

27 
